\title{
Synoptic Survey of Water Quality and Bottom Sediments, San Juan Bay Estuary System, Puerto Rico, December 1994-July 1995
}

By Richard M.T. Webb and Fernando Gómez-Gómez

U.S. GEOLOGICAL SURVEY

Water-Resources Investigations Report 97-4144

Prepared in cooperation with the

PUERTO RICO ENVIRONMENTAL QUALITY BOARD and U.S. ENVIRONMENTAL PROTECTION AGENCY for the SAN JUAN BAY ESTUARY PROGRAM 


\title{
U.S. DEPARTMENT OF THE INTERIOR \\ BRUCE BABBITT, Secretary
}

\author{
U.S. GEOLOGICAL SURVEY
}

Thomas J. Casadevall, Acting Director

Use of trade names in this report is for identification purposes only and does not imply endorsement by the U.S. Government.

For additional information write to:

District Chief

U.S. Geological Survey

GSA Center, Suite 400-15

651 Federal Drive

Guaynabo, Puerto Rico 00965
Copies of this report can be purchased from:

U.S. Geological Survey

Branch of Information Services

Box 25286

Denver, CO 80225-0286 


\section{CONTENTS}

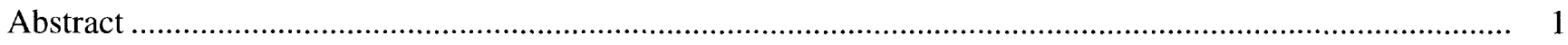

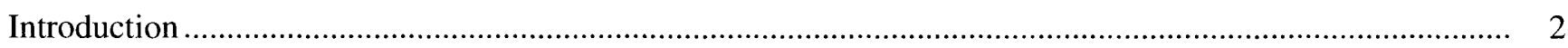

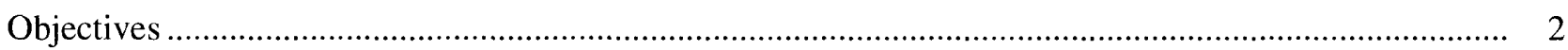

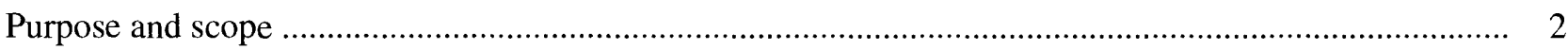

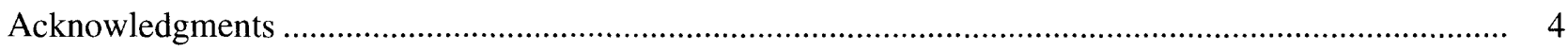

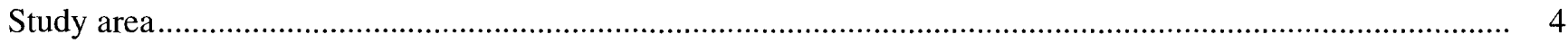

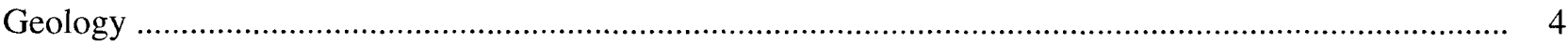

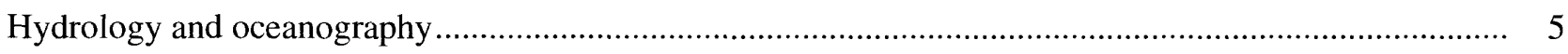

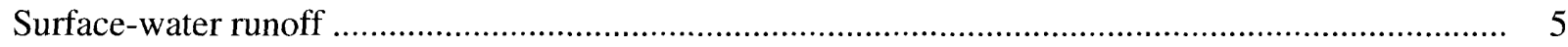

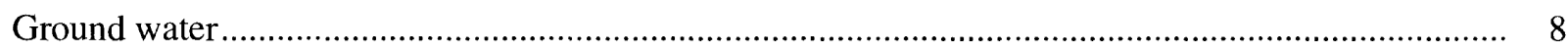

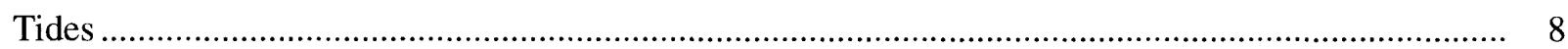

Coastal ocean currents, wave climate, and storm surge ........................................................... 8

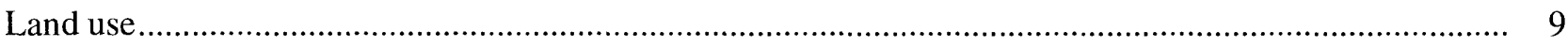

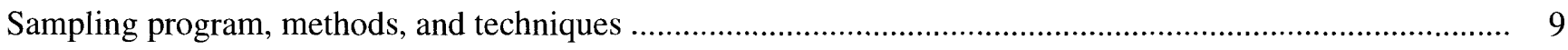

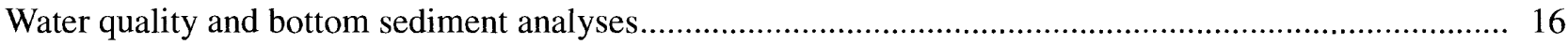

Bottom sediment cores and sedimentation rates........................................................................ 20

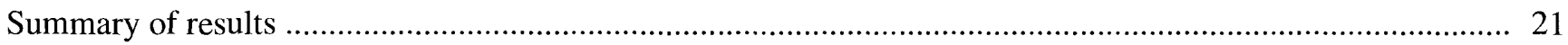

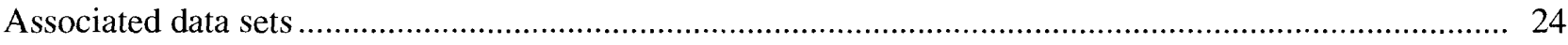

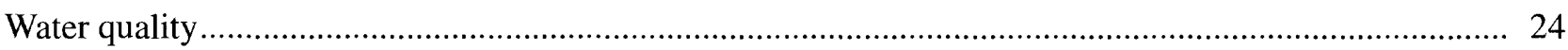

Field observations of temperature, specific conductance, $\mathrm{pH}$, and dissolved oxygen ...................... 24

Secchi depth, color, turbidity, and suspended solids in the surface waters .................................... 26

Dissolved nutrients, chlorophyll, and fecal coliform bacteria in the surface waters ......................... 27

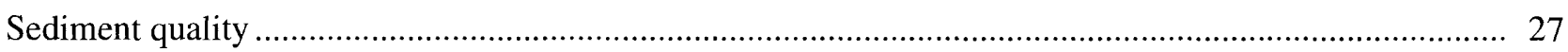

Texture, macronutrients, and total carbon analyses of surficial bottom sediments ........................... 28

Texture and cesium-137 analytical results for discrete depth intervals of core samples .................... 29

Organic compounds and trace element concentrations for homogenized core samples

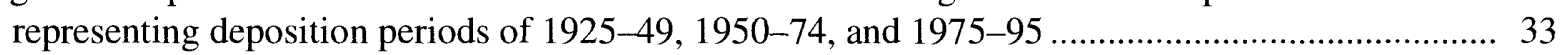

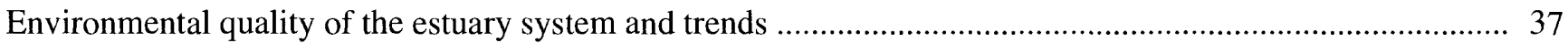

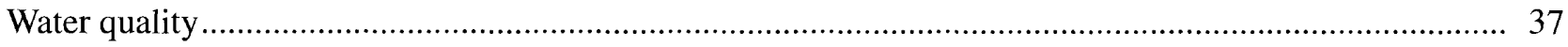

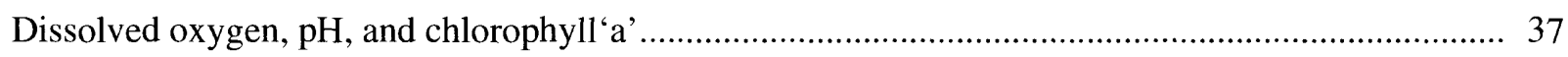

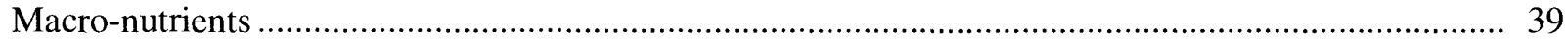

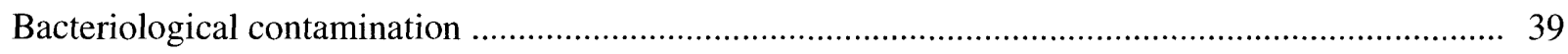

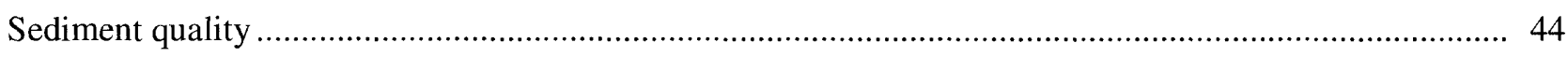

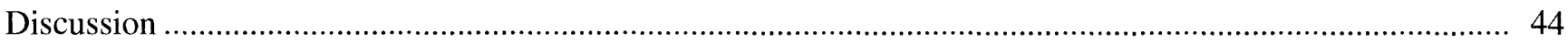

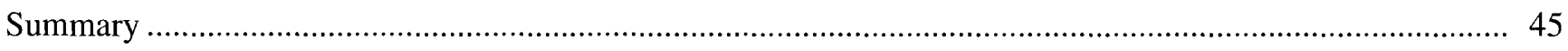

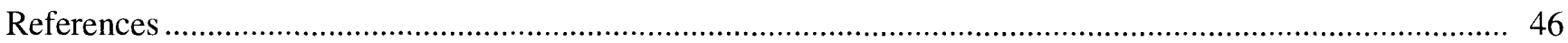




\section{APPENDIXES}

1. In-situ determination of specific conductance, $\mathrm{pH}$, and dissolved oxygen levels with depth for sediment and water-quality sites sampled in March, May, and July 1995, San Juan Bay estuary system, Puerto Rico

2. Secchi depth, color, turbidity, and total suspended solids in the surface waters for 15 exploratory water-quality sites sampled during March 1995 and May 1995, San Juan Bay estuary system, Puerto Rico

3. Analytical results for dissolved nutrients, fecal coliform bacteria, and chlorophyll 'a' and 'b' for 15 exploratory water-quality sites sampled during March 1995 and May 1995, San Juan Bay estuary system, Puerto Rico

4. Particle-size distribution, moisture content, nutrients and total carbon concentrations in surficial bottom sediment samples at nine exploratory designated bottom sediment sampling sites and at the six detailed sediment-sampling sites, San Juan Bay estuary system, Puerto Rico

5. Particle-size distribution and cesium-137 analytical results for discrete depth intervals at six bottom sediment core sites, San Juan Bay estuary system, Puerto Rico

6. Analytical results for organochlorine pesticides and total PCB detected above the minimum reporting level in selected horizons corresponding to depositional periods of 1925-49, 1950-74, and 1975-95 at six core sites sampled July 18-19, 1995, San Juan Bay estuary system, Puerto Rico

7. Trace element concentrations in core samples for selected horizons corresponding to depositional periods of 1925-49, 1950-74, and 1975-95 at six core sites samples July 18-19, 1995, San Juan Bay estuary system, Puerto Rico.

\section{ILLUSTRATIONS}

1. Map showing drainage basin of the San Juan Bay estuary and site localities in Puerto Rico

2. Wind roses showing average wind conditions for San Juan, Puerto Rico

3. Map showing generalized surficial geology of the San Juan Bay estuary drainage basin in northern Puerto Rico.

4. Diagram of average daily water flows for dry weather conditions in the San Juan Bay estuary system in northern Puerto Rico

5.-19. Maps showing:

5. Progressive urbanization of the San Juan Metropolitan area from 1900 through 1970 10

6. Land use in the San Juan Bay estuary system in Puerto Rico in 1977 
7. Locations of water and sediment quality sites sampled in the Bahía de San Juan, Puerto Rico.

8. Locations of water and sediment quality sites sampled in Caño de Martín Peña and Laguna San José, Puerto Rico.

9. Locations of water and sediment quality sites sampled in Canal Suárez, Laguna La Torrecilla, Laguna de Piñones, and Bosque Estatal de Piñones, Puerto Rico...

10. Location of 42 USGS quality-of-water stations in the San Juan Bay estuary drainage basin in northern Puerto Rico

11. Total phosphorus concentrations in surficial bottom sediment samples, San Juan Bay estuary system, Puerto Rico

12. Total phosphorus concentrations and trends at the USGS-Commonwealth of Puerto Rico Cooperative program quality-of-water stations in the San Juan Bay estuary system, Puerto Rico, for the period 1970-95.

13. PCBs, Dieldrin, and DDT plus metabolites concentrations in the bottom sediments at the six core sites in the San Juan Bay estuary system, Puerto Rico, for the estimated time periods $1925-49,1950-74$, and 1975-95....

14. Lead, mercury, and arsenic concentrations in the bottom sediments at six core sites in the San Juan Bay estuary system, Puerto Rico, for the estimated periods 1925-49, 1950-74, and 1975-95.

15. Total recoverable lead concentrations and trends at selected USGS-Commonwealth of Puerto Rico Cooperative program quality-of-water stations located in the San Juan Bay estuary system drainage basin, Puerto Rico, for the period 1980-95

16. Dissolved oxygen, $\mathrm{pH}$, and chlorophyll 'a' determinations and trends at selected USGS-Commonwealth of Puerto Rico Cooperative program quality-of-water stations in the San Juan Bay estuary system, Puerto Rico, for the period 1970-95

17. Total orthophosphorus, total nitrogen, total Kjeldahl nitrogen, and total nitrate + nitrite concentrations and trends at selected USGS-Commonwealth of Puerto Rico Cooperative program quality-of-water stations in the San Juan Bay estuary system, Puerto Rico, for the period 1970-95.

18. Fecal coliform counts obtained as part of the quality-of-water synoptic surveys conducted in the San Juan Bay estuary system, Puerto Rico, March and July 1995

19. Fecal coliform counts and trends at selected USGS-Commonwealth of Puerto Rico Cooperative program quality-of-water stations in the San Juan Bay estuary system, Puerto Rico, for the period 1970-95 


\section{TABLES}

1. Summary of the San Juan Bay estuary system study sampling plan including station types, field variables measured, and laboratory analyses

2. Water depth locations and station types of sampling sites in the San Juan Bay estuary system, Puerto Rico

3. Analytes, sample quantities, preservation techniques, and maximum holding times

4. Analytical procedures for exploratory designated water-quality samples

5. Analytical procedures for exploratory sediment-quality samples

6. Analytes and methods used in sediment core samples

7. Average vertical accretion rates, and depth intervals representing the periods 1975-95, 1950-74, and 1925-49 for the six detailed sediment-sampling sites

8. Sediment quality guidelines for organic compounds and trace elements detected above minimum reporting limits in the core samples collected from the San Juan Bay estuary system, Puerto Rico

\section{CONVERSION FACTORS, ABBREVIATED WATER-QUALITY UNITS, AND ACRONYMS}

\begin{tabular}{rcl}
\hline Multiply & By & To obtain \\
\hline cubic meter $\left(\mathrm{m}^{3}\right)$ & 35.315 & cubic foot \\
cubic meter $\left(\mathrm{m}^{3}\right)$ & 0.0008107 & acre-foot \\
cubic meter per second $\left(\mathrm{m}^{3} / \mathrm{s}\right)$ & 35.315 & cubic foot per second \\
cubic meter per second $\left(\mathrm{m}^{3} / \mathrm{s}\right)$ & 15850 & gallon per minute \\
cubic meter per second $\left(\mathrm{m}^{3} / \mathrm{s}\right)$ & 22.826 & million gallons per day \\
kilogram per square kilometer $\left(\mathrm{kg} / \mathrm{km}^{2}\right)$ & 0.002855 & ton per square mile \\
kilometer $\left(\mathrm{km}^{2}\right)$ & 0.62137 & mile \\
meter $(\mathrm{m})$ & 3.2808 & foot \\
million cubic meters $\left(\mathrm{Mm}^{3}\right)$ & 810.71 & acre-foot \\
square killiometer $\left(\mathrm{km}^{2}\right)$ & 810.71 & acre-foot per year \\
square kilometer $\left(\mathrm{km}^{2}\right)$ & 247.11 & acre \\
square meter $\left(\mathrm{m}^{2}\right)$ & 0.3861 & square mile \\
& 10.764 & square foot \\
\hline
\end{tabular}

Specific conductance, in microsiemens per centimeter $(\mu \mathrm{S} / \mathrm{cm})$ at $25^{\circ} \mathrm{C}$ can be converted to an approximately equivalent salinity value, in parts per mil (\%o), by multiplying by 0.00068 . This value was calculated from 55 measurements of waters in the Bahía de San Juan and Laguna San José over the last 20 years.

Horizontal Datum-Puerto Rico Datum, 1940 Adjustment (Similar to North American Datum of 1927)

Vertical Datum—National Geodetic Vertical Datum 1929 (NGVD29) 


\section{ACRONYMS}

DGPS Differential Global Positioning System

PRDNER Puerto Rico Department of Natural and Environmental Resources

PREQB Puerto Rico Environmental Quality Board

USACE U.S. Army Corps of Engineers

USEPA U.S. Environmental Protection Agency

USGS U.S. Geological Survey

Locality names used in this report are in Spanish, whereas the USGS sampling sites are identified as they appear in the National Water Information System data base (most often English translations of the site locality). The following translations of selected common words are provided to improve understanding:

$\begin{array}{ll}\text { Spanish } & \text { English } \\ \text { bahía } & \text { bay } \\ \text { bosque } & \text { forest } \\ \text { caño } & \text { channel or drainage ditch } \\ \text { canal } & \text { canal or channel } \\ \text { de } & \text { of } \\ \text { estatal } & \text { state } \\ \text { grande } & \text { grand or large } \\ \text { el, los, la, las } & \text { the } \\ \text { lago } & \text { lake } \\ \text { laguna } & \text { lagoon } \\ \text { quebrada } & \text { stream or creek } \\ \text { río } & \text { river }\end{array}$

USGS data stations in this report have been assigned unique names and identification numbers. The qualityof-water station at Quebrada Blasina, for example, has been assigned the number 50050300, consisting of a 2 digit region code, '50' for Puerto Rico, followed by a unique 6-digit number '050300' based on the specific drainage basin and its downstream order. Since the 6-digit part of all stations used in this report begins with zero, all stations will be referred to by their complete 8-digit number, or by their last 5 digits. 


\title{
Synoptic Survey of Water Quality and Bottom Sediments, San Juan Bay Estuary System, Puerto Rico, December 1994-July 1995
}

\author{
By Richard M.T. Webb and Fernando Gómez-Gómez
}

\section{Abstract}

During 1994 and 1995, the U.S. Geological Survey, in cooperation with the U.S.

Environmental Protection Agency and the Puerto Rico Environmental Quality Board carried out a synoptic sampling of the quality of water (dry and wet periods) and sediment of the San Juan Bay estuary system for the San Juan Bay Estuary Program. Secchi depth at 15 sampling sites ranged from 12 to 152 centimeters. Turbidity values were less than or equal to 11 nephelometric turbidity units at all sites whereas total suspended solids were less than 31 milligrams per liter. Caño de Martín Peña had elevated ammonia concentrations (2.3 milligrams of ammonia as nitrogen per liter) and counts of fecal-coliform bacteria on the order of 100,000 colonies per 100 milliliters. At none of the other sampled sites did dissolved ammonia exceed 0.45 milligrams per liter or fecal coliform concentrations exceed 6,000 colonies per 100 milliliters. Concentrations of dissolved oxygen in the eutrophic Laguna San José ranged from near zero to more than 200 percent saturation levels. Sedimentation rates at six coring sites varied from 0.24 centimeters per year in Laguna de Piñones to 3.9 centimeters per year in Caño de Martín Peña, as determined by downcore activity of cesium-137. At Caño de Martín Peña, the PCB concentrations increased from 12 micrograms per kilogram in the oldest strata (pre-1950) to 380 micrograms per kilogram in the most recently deposited sediments (197595). Also at the Caño de Martín Peña site, concentrations of DDT (and metabolites), a pesticide used extensively from the 1940s through the end of the 1960s, were highest (at 62 micrograms per kilogram) in the sediments deposited from 1950 to 1974 , decreasing to 27 micrograms per kilogram in sediments deposited from 1975-95. Bis(2-ethylhexl) phthalate, a common plasticizing agent, exceeded 20,000 micrograms per kilogram in the most recent strata of the Caño de Martín Peña core site; the likely source being the PVC and other plastics contained in the construction debris commonly used for fill in the squatter communities. Lead concentrations increased at the Caño de Martín Peña core site from 30 micrograms per gram in the oldest strata to 750 micrograms per gram in the most recent strata; similarly, mercury increased from 0.16 to 4.7 micrograms per gram. Analysis of data collected from 1970 to 1995 indicates that since 1985 , the quality of water in the San Juan Bay estuary system has improved as leaded gasoline has been phased out and wastewater from local plants, previously discharged to inland waters, is now collected and routed to regional facilities for discharge to offshore ocean outfalls. 


\section{INTRODUCTION}

The Clean Water Act of 1977, as amended by the Water Quality Act of 1987, formally established the National Estuary Program with the goal of providing guidance to local decision makers in restoring the health of estuaries of national significance. Coordination between the Puerto Rico Environmental Quality Board (PREQB) and the U.S. Environmental Protection Agency (USEPA) resulted in the inclusion of San Juan Bay (Bahía de San Juan), and its lagoons and interconnecting waterways, into the National Estuary Program beginning in 1993. The local implementation of the program is the San Juan Bay Estuary Program. The principal objective of the program is to develop a Comprehensive Conservation and Management Plan (CCMP). The CCMP will provide guidance for government, private industry, and citizens as they work together to improve the environmental quality of the estuarine system.

The San Juan Bay estuary system is contained within a relatively small drainage basin $\left(240 \mathrm{~km}^{2}\right)$ above a broad, flat coastal plain (fig. 1). The subtidal portion of the system consists of the Bahía de San Juan, connected by a series of natural and dredged channels to four lagoons: Laguna del Condado, Laguna San José, Laguna La Torrecilla, and Laguna de Piñones. Laguna de Piñones is located within the Bosque Estatal de Piñones, the largest remaining mangrove forest in Puerto Rico. The forest is connected to the estuarine reach of the Río Grande de Loíza through a series of gated canals constructed to drain the forest and to facilitate transport of mangrove harvested for charcoal production. Intense rainfall in eastern Puerto Rico can cause the Río Grande de Loíza to rise above the gates and dikes, and flood the eastern part of the estuary system. The water quality of the bay, lagoons, and interconnecting natural and manmade channels has been significantly altered from its natural state not only by land-use activities, but also by modification of the hydraulic properties through dredging of channels and placement of fill (Ellis, 1976; Seguinot-Barbosa, 1983). In places the estuary system is hypereutrophic, has anoxic bottom waters, is contaminated by heavy metals, trace elements, and organic compounds; and receives raw-sewage from combined storm-sewer overflows and from direct discharges from housing along parts of its perimeter.

\section{Objectives}

The objectives of this study were to:

1) document general water-quality conditions in the estuary system during a dry period and immediately after a significant storm-runoff event;

2) characterize the physical and chemical composition of sub-tidal sediments throughout the bay and lagoons; and

3) relate the water-quality and sediment data acquired as part of this study to observations documented in previous studies.

The U.S. Geological Survey (USGS) conducted this study, in cooperation with the USEPA and the Puerto Rico Environmental Quality Board (PREQB), to provide the water-quality and sediment data required by the San Juan Bay Estuary Program in order to prioritize actions to be included in the CCMP.

\section{Purpose and Scope}

This report presents the results of the synoptic survey of water quality and bottom sediments of the San Juan Bay estuary system, Puerto Rico. The data, collected between December 1994 and July 1995, include:

- General water quality observations made at 15 sites during dry weather conditions and immediately after a storm-runoff event. Variables measured at each site include water depth, color, and vertical profiles of temperature, specific conductance, $\mathrm{pH}$, and dissolved oxygen. In addition, samples collected near the surface of the water column at each site were analyzed for turbidity, total suspended solids, nitrate, nitrite, ammonia, orthophosphate, fecal-coliform bacteria, chlorophyll'a', and chlorophyll 'b'.

- Analysis of grain-size distribution and concentrations of total Kjeldahl nitrogen, total phosphorus, and total carbon in the surficial sediments at 15 sites.

- Analysis of grain-size distribution and concentrations of total Kjeldahl nitrogen, total phosphorus, total carbon, and of the activity of the radioisotope cesium-137 (Cs-137) in sediment cores obtained at six sites. 

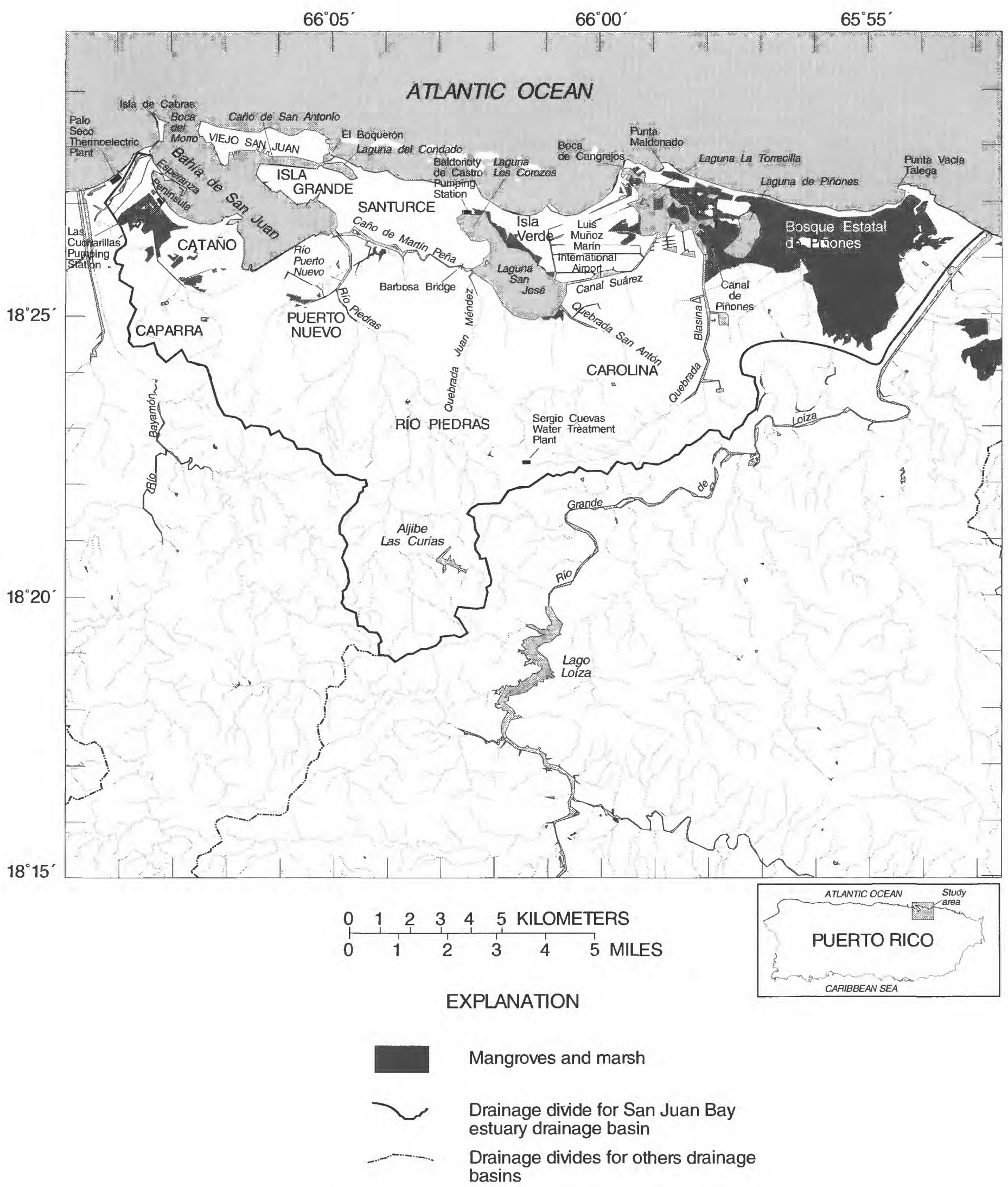

Figure 1. Drainage basin of the San Juan Bay estuary and site localities in Puerto Rico. 
- Estimates of average sedimentation rates at the six sediment core sites as determined from the activity of Cs-137 in the sediment cores. The estimated sedimentation rates were used to define strata containing sediments and associated constituents deposited during discrete time periods corresponding approximately to $1925-49,1950-74$, and 1975-95.

- Concentrations of selected pesticides, trace elements, and semi-volatile organic compounds deposited at the six core sites during the approximate time periods 1925-49, 1950-74, and 1975-95.

The results of the dry-weather/wet-weather water-quality sampling in the San Juan Bay estuary system are complemented with associated data sets compiled by the USGS in cooperation with Federal and Commonwealth agencies over the last 25 years.

Changes in the composition of the sediments deposited during each approximated time period are related in general terms to land-use changes and the changing loads of selected contaminants. Concentrations of trace elements in the oldest (deepest) sediment samples can be taken to represent natural baseline concentrations.

\section{Acknowledgments}

Dr. Sherwood McIntyre, Agronomist with the United States Department of Agriculture, Water Quality and Watershed Research Laboratory, assisted in the initial coring operations to obtain the samples needed to estimate sedimentation rates using the activity of Cs-137. Senén Guzmán-Ríos, Caribbean District Water-Quality Specialist, validated the data included in this report. Javier Ruíz-Nieves and Mario Oliveras-Feliciano, Volunteers for Science, assisted greatly both in the field and during data reduction. Sandra Galarza-Rivera's help with data entry and analysis is greatly appreciated. The authors would also like to thank Ramón Carrasquillo, Luis Soler, Miguel Rodríguez, Ivette Reyes, and Luis Jorge Herrera for assisting in field sampling and laboratory analysis and Francisco Maldonado, Ruth Guzmán, and Luis Menoyo for helping produce the final report.

\section{STUDY AREA}

The San Juan Bay estuary system lies almost entirely within the San Juan metropolitan area with the exception of the easternmost part which consists of the Bosque Estatal de Piñones mangrove forest reserve.
The normal range of mean monthly temperatures in San Juan is only $3.2^{\circ} \mathrm{C}$ between the warmest month, August $\left(27.1^{\circ} \mathrm{C}\right)$, and the coolest months, January and February $\left(23.9^{\circ} \mathrm{C}\right)$ (Calvesbert, 1970). Mean-annual rainfall varies from $1,500 \mathrm{~mm}$ near the coast in the San Juan area to $2,100 \mathrm{~mm}$ in the uplands defining the southern boundary of the drainage basin. Most of the rainfall occurs from July to September and is related to easterly waves which pass through the region at an average rate of four to six times per month (Nieuwolt, 1977). From August to October, tropical depressions, some of which develop into hurricanes, commonly pass through the region and deliver torrential rains. A second annual peak in rainfall amount occurs in May, responding to disturbances formed as occasional cold air masses from the North American continent enter the region from the west. Pan evaporation at the coast averages about $2,070 \mathrm{~mm} / \mathrm{yr}$, and is, to a large degree, the result of the Trade Winds which blow almost invariably from the northeast (fig. 2).

\section{Geology}

Almost all of the most common geomorphic terranes of Puerto Rico are present in the watershed (fig. 3). These include volcaniclastic and plutonic rocks typical of the center of the island, limited exposures of the extensive limestone deposits that cover much of northern Puerto Rico, and alluviumcovered valleys and coastal plains. The drainage basin of the San Juan Bay estuary system covers $240 \mathrm{~km}^{2}$, of which $215 \mathrm{~km}^{2}$ is land and $25 \mathrm{~km}^{2}$ is covered by water. The volcaniclastic and intrusive rocks in the uplands cover $55 \mathrm{~km}^{2}$, the limestone formations cover $13 \mathrm{~km}^{2}$, whereas Quaternary deposits - which include marine and riverine terrace deposits, alluvium, beach and swamp deposits, blanket deposits, and artificial fill - cover $147 \mathrm{~km}^{2}$.

The predecessors to both the Río Grande de Loíza and the Río Bayamón apparently passed through the estuary system in the past (Rodríguez and others, 1992, Kaye, 1959a and 1959b) and deposited most of the Quaternary alluvium and coastal deposits that blanket the San Juan Bay estuary system today. Mangrove and swamp deposits, which cover $27 \mathrm{~km}^{2}$. are limited to protected low-energy parts of the bay and lagoons. As recently as 1,500 years ago, the bay north of Isla Verde was a sheltered mangrove community that was drowned as sea level rose following the most recent glacial period (Cintrón and 


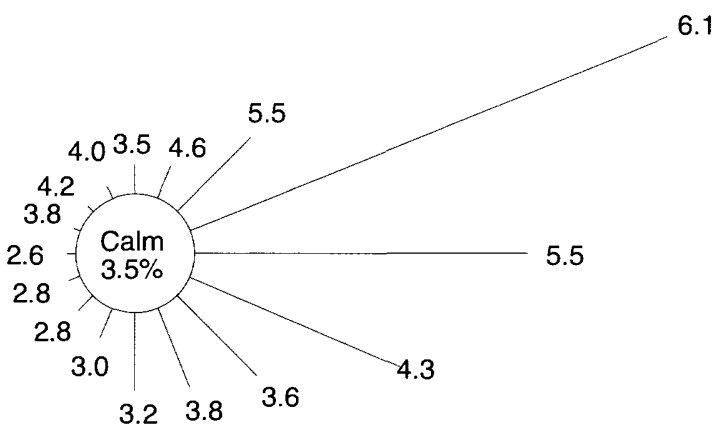

Daytime hours (6:30 am - 6:30 pm)

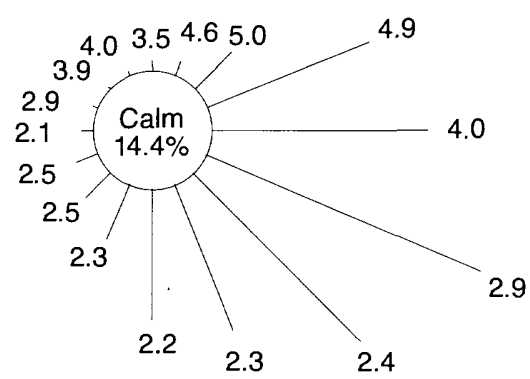

Nighttime hours $(6: 30 \mathrm{pm}-6: 30 \mathrm{am})$ $\begin{array}{lllllll}0 & 5 & 10 & 15 & 20 & 25 & 30\end{array}$

Percentage of time that wind blows from the indicated direction. The mean wind speed, in meters per second, is indicated at the end of each ray.

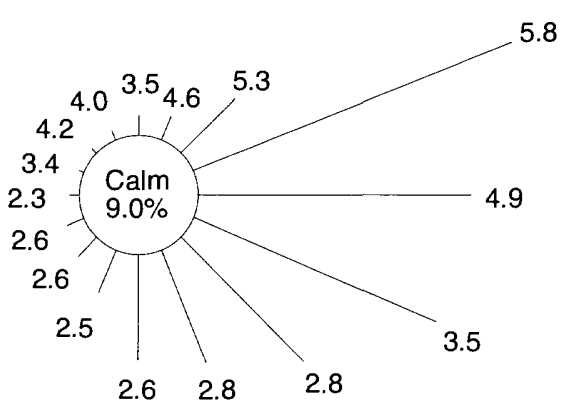

All hours

Figure 2. Average wind conditions for San Juan, Puerto Rico (Source data: National Climatic Data Center, 1995, Period of record: 1955-90).

others, 1984). Beach deposits, which cover $10 \mathrm{~km}^{2}$, include the consolidated sand dunes at Isla de Cabras, Old San Juan and the headlands of Boca de Cangrejos, Punta Maldonado, and Punta Vacía Talega. Eleven $\mathrm{km}^{2}$ of quartz-sand blanket deposits underlie Santurce, northern Laguna San José, and Laguna La Torrecilla. Reflecting the intense development of the San Juan Metropolitan area, $29 \mathrm{~km}^{2}$ (12 percent of the watershed) is covered with artificial fill.

\section{Hydrology and Oceanography}

Surface water quality in the estuary system and the nearshore areas is closely related to surface-water runoff, ground water, tides, and currents in the lagoons and nearshore marine waters (fig. 4).

\section{Surface-Water Runoff}

The steep topography and the almost complete urbanization of the drainage basin results in extremely flashy rainfall-runoff events. The extensive impermeable surfaces laid down during urbanization has led to flooding which constitutes a critical problem not only in areas receiving drainage from the Río Piedras, the main stream in the estuary system, but also in areas adjacent to many of the smaller tributaries in the estuary system basin.

Runoff from the Río Piedras at the USGS longterm gaging station 50049000 , which monitors drainage from $32.4 \mathrm{~km}^{2}$, averages about $26 \mathrm{Mm}^{3} / \mathrm{yr}$ (15-year record), equivalent to $810 \mathrm{~mm}$ of the average rainfall of $2,000 \mathrm{~mm} / \mathrm{yr}$. This indicates that the ratio for runoff to rainfall above the gage site is approximately 0.40 . Taking into consideration that 


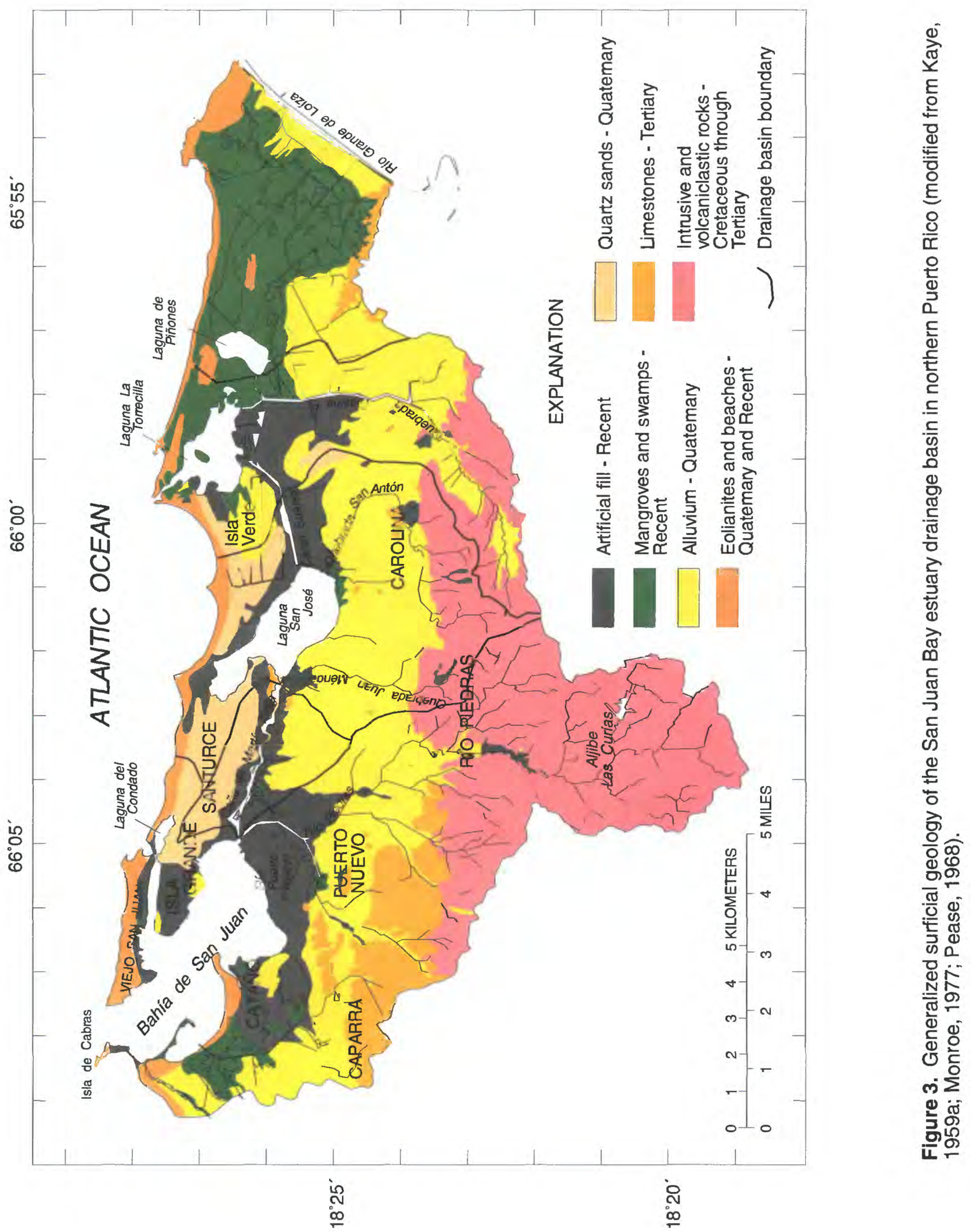




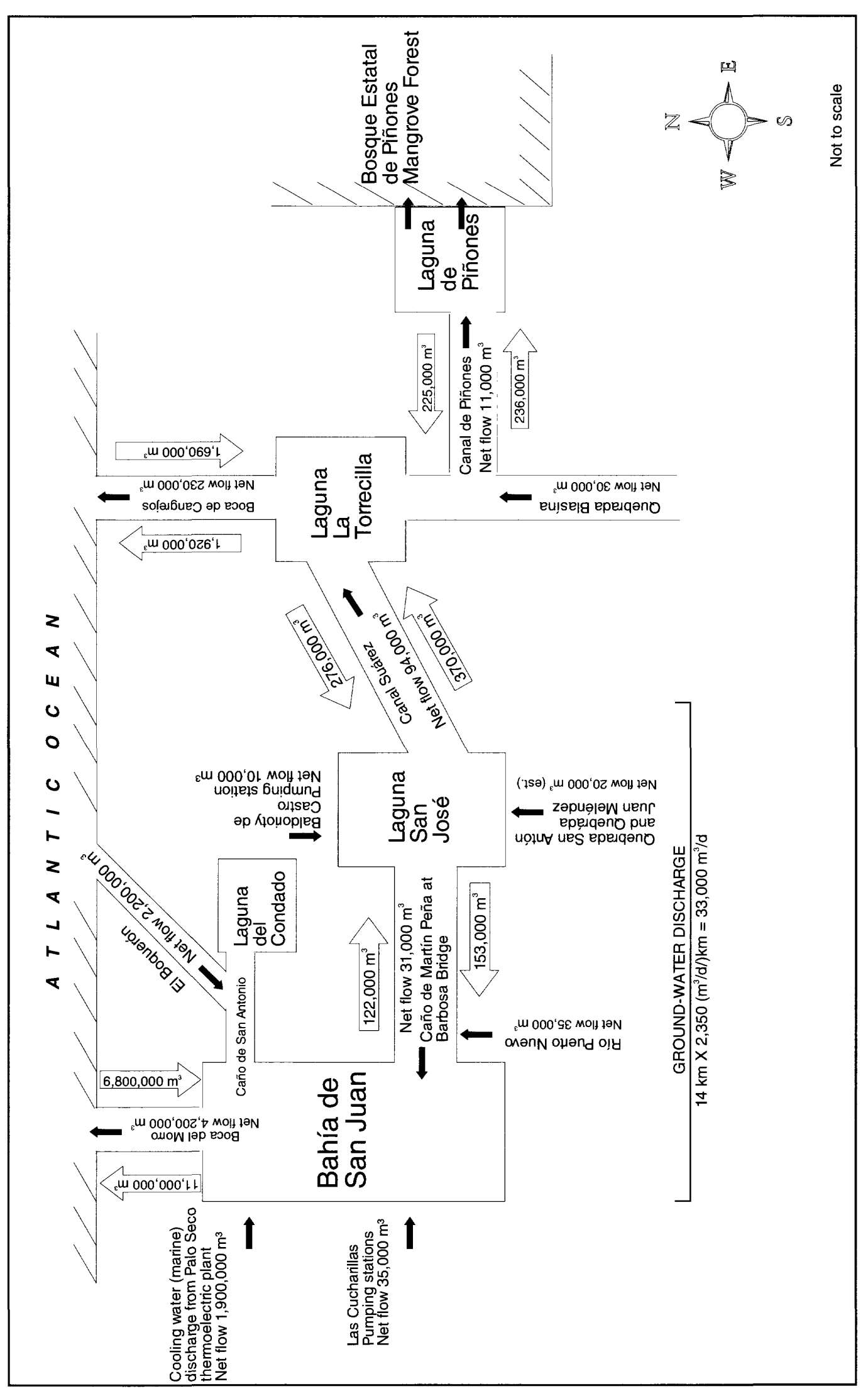

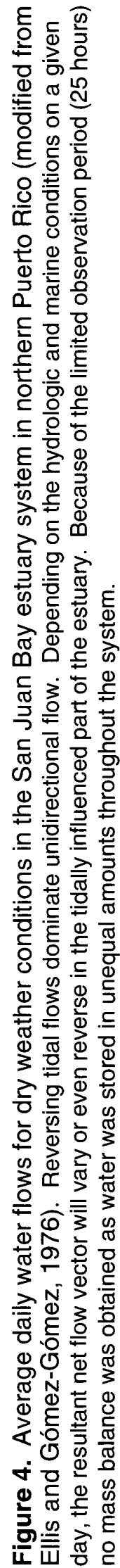


urban development of the estuary system drainage basin is most significant downstream of the long-term streamflow gage site and within the smaller tributaries, it can reasonably be estimated that the ratio of runoff to rainfall for the other parts of the basin is approximately 0.60 . If a value of 0.60 is used, then the mean annual runoff to the estuary system can be estimated to be on the order of $185 \mathrm{Mm}^{3} / \mathrm{yr}$. For comparison, over a 25-hour tidal cycle approximately $10 \mathrm{Mm}^{3}$ of seawater from the Atlantic Ocean enter and leave the estuary system.

It is common for river and storm-water discharges to dominate tidal flow patterns in the estuary system, especially in the areas with restricted connections to the open sea. Gómez-Gómez and others (1983) studied the hydraulic characteristics and loads of the estuary system during a tidal cycle during which $70 \mathrm{~mm}$ of rain fell over the metropolitan area within a 12-hour period. The rainfall event had a frequency of less than one year (a relatively common event) and generated sufficient storm-runoff to change the tidal flows within Laguna San José, Laguna La Torrecilla, and Laguna de Piñones. Runoff into Laguna San José, Laguna La Torrecilla, and Laguna Piñones from the $70 \mathrm{~mm} / 12$-hour rainfall event totaled about $3.6 \mathrm{Mm}^{3}$, which is approximately 20 percent of the total volume of these lagoons.

In addition to the surface water discharge by streams to the estuary system, there are discharges from urban "flood control" drainage pumps to the Bahía de San Juan, Caño de Martín Peña, and Laguna San José. Combined sanitary/fluvial connections and raw sewage discharges have direct impacts on the water quality. Quebrada Blasina, which discharges into Laguna La Torrecilla, also receives discharge from the backwash of the Puerto Rico Aqueduct and Sewer Authority (PRASA) Sergio Cuevas Water Treatment Plant.

\section{Ground Water}

The principal aquifer in the area is the unconfined to semi-confined upper aquifer contained in the Aguada Limestone and Cibao Formation and the confined aquifer contained at depth in the Mucarabones Sand. The yield of wells tapping the upper aquifer average $32 \mathrm{~L} / \mathrm{s}$, almost twice that of wells tapping the Mucarabones Sand aquifer $(15 \mathrm{~L} / \mathrm{s})$ (Anderson, 1976). Areas unfavorable for well development are to the north of the 5-m altitude topographic contour, where wells yield brackish water. The confined aquifer yields water which is slightly saline (dissolved solids of $1,000 \mathrm{mg} / \mathrm{L}$ or more) and is not tapped by wells except in areas near its outcrop to the south. Ground-water discharge occurs mainly to streams within the lower parts of the basin and the aquifers are non-existent northward of Caño de Martín Peña. Ground-water discharge from the upper aquifer to the estuary system is limited to a segment of about $14 \mathrm{~km}$ from Bahía de San Juan to Laguna San José. Discharge to these water bodies is estimated at about $33,000 \mathrm{~m}^{3} / \mathrm{d}$.

\section{Tides}

Tides in San Juan are mixed semidiurnal with two highs and two lows of unequal height every day. The tidal range between the mean elevation of the lowest of the two low waters and the mean of the highest of the two high waters is $48.8 \mathrm{~cm}$ (Elmo Long, National Oceanic and Atmospheric Administration, personal commun., 1989). The magnitude of daily tidal oscillations varies within the estuary system and is controlled primarily by the hydraulic characteristics of the channels and surface areas of each water body. Full-range oscillations, with only minor dissipation, occur at Laguna La Torrecilla, Laguna del Condado, and in the Bahía de San Juan. Tidal oscillations at Laguna San José and Laguna de Piñones are limited to about $5 \mathrm{~cm}$. With the exception of the Bahía de San Juan and Laguna del Condado, tidal oscillations have been significantly modified in the estuary system by dredging activities. As an example, daily tidal oscillations at Laguna de Piñones may have been negligible prior to the dredging of Canal de Piñones and tidal flows at Laguna La Torrecilla would have been capable of turning over its entire volume as much as twice each week.

\section{Coastal Ocean Currents, Wave Climate, and Storm Surge}

Along the north coast of Puerto Rico, the littoral current is generally to the west as the most common winds and waves arrive from the northeast (Kaye, 1959b; Velázco-Domínguez and others, 1986). The wind is also an important factor in the bays and lagoons behind the beaches as debris and dead fish almost inevitably end up on the western shores. 
Littoral currents parallel to the shore are produced by waves approaching the coast at an angle; churning waters and sediments are pushed in a zig-zag trajectory down the coast with each set of waves. The effect of the littoral currents is particularly clear on the Esperanza peninsula in the Bahía de San Juan. The peninsula was initially formed with the sediments dredged to create the deep-draft navigation channels in the Bay. The waves approaching the spit from the north have pushed sediments to the southeast towards the Cataño shoreline forming a recurved spit. The littoral currents at the ocean outlet of Laguna del Condado also dominate the tides in inducing water circulation through El Boquerón, the tidal inlet between Condado and Viejo San Juan. At this location, the flux of seawater is almost continuously westward toward Caño San Antonio and into the Bahía de San Juan. Only on rare occasions does an ebb tide flowing north out of Condado Lagoon toward the ocean exist, possibly occurring only during periods when the predominant northeast Trade Winds are calm with winds instead from the north or northeast.

The narrow insular shelf off of the north coast limits the size of storm surges generated by storm winds and swells. The highest storm surge, the stillwater elevation above the predicted astronomical tide, recorded at the San Juan tide gage was $73 \mathrm{~cm}$. This storm surge occurred in November of 1982 as large volumes of seawater were pushed into the bay by swells 3 to $4 \mathrm{~m}$ high that were generated by a large storm in the North Atlantic. For comparison, Hurricane Hugo, with more transient seas but lower atmospheric surface pressure, produced a storm surge of $70 \mathrm{~cm}$ above the predicted astronomical tide (National Oceanic and Atmospheric Administration, 1989). Although the storm surges are limited in amplitude, the potential impact of high seas on the coastline of the estuary continues to increase as development continues to encroach into the littoral zone and natural protective structures are debilitated (Bush and others, 1995; Velázco-Domínguez and others, 1986).

For centuries, much of the energy of the ocean swells that impinged on the coast in the San Juan area was absorbed by the extensive sand dunes from El Boquerón (ocean inlet at Laguna del Condado) to Punta Vacía Talega. Much of this front line defense was eliminated in the 1950's as dunes more than $10 \mathrm{~m}$ high in the Piñones coastal area were extensively mined as fill for the Luis Muñoz Marín International Airport built between Laguna San José and Laguna La Torrecilla (Benedetty and Cruz, 1980). Now even moderate energy waves, occurring on an average of once or twice a year, overwash parts of Highway 187 east of Punta Maldonado where the dune once existed. The breach in the dune line also served as an outlet for floods produced by the Río Grande de Loíza in 1970 (Haire, 1975).

\section{Land Use}

The amount of urban area in the San Juan Bay estuary system has increased rapidly this century (fig. 5). Land-use maps produced from aerial photos taken in 1977 show that urban areas covered $98 \mathrm{~km}^{2}$ (41 percent) of the $240-\mathrm{km}^{2}$ basin. The other land-use types in the estuary system's drainage basin are wetlands, $28 \mathrm{~km}^{2}$; water bodies, $25 \mathrm{~km}^{2}$; public buildings, schools, and parks, $24 \mathrm{~km}^{2}$; undeveloped urban, $23 \mathrm{~km}^{2}$; pasture, $18 \mathrm{~km}^{2}$; forest, $11 \mathrm{~km}^{2}$; agriculture, $4.5 \mathrm{~km}^{2}$; bare ground, $4.4 \mathrm{~km}^{2}$; squatter communities, $2.8 \mathrm{~km}^{2}$; and rural, $1.2 \mathrm{~km}^{2}$ (fig. 6). Since 1977, extensive areas of pasture and forest in the uplands of the Río Piedras watershed have been urbanized with housing and commercial development.

The total population living within the basin is approximately 622,000 as estimated from the 1990 census (U.S. Department of Commerce, 1991) weighted by the percentage of the barrio (ward) that fell within the estuary system's drainage basin boundary. The average population density is 3,215 persons per square kilometer. Population densities range from a minimum of 94 persons per square kilometer in the area of the Bosque Estatal de Piñones, to 8,300 persons per square kilometer in the business district of Río Piedras (Hato Rey) where high-rise condominiums are prevalent.

\section{SAMPLING PROGRAM, METHODS, AND TECHNIQUES}

Field data obtained and analyses conducted in this synoptic study were selected to describe the overall quality of the water and sediments in the estuary system, and to document temporal and spatial variations of selected contaminants in the sediments (table 1). 


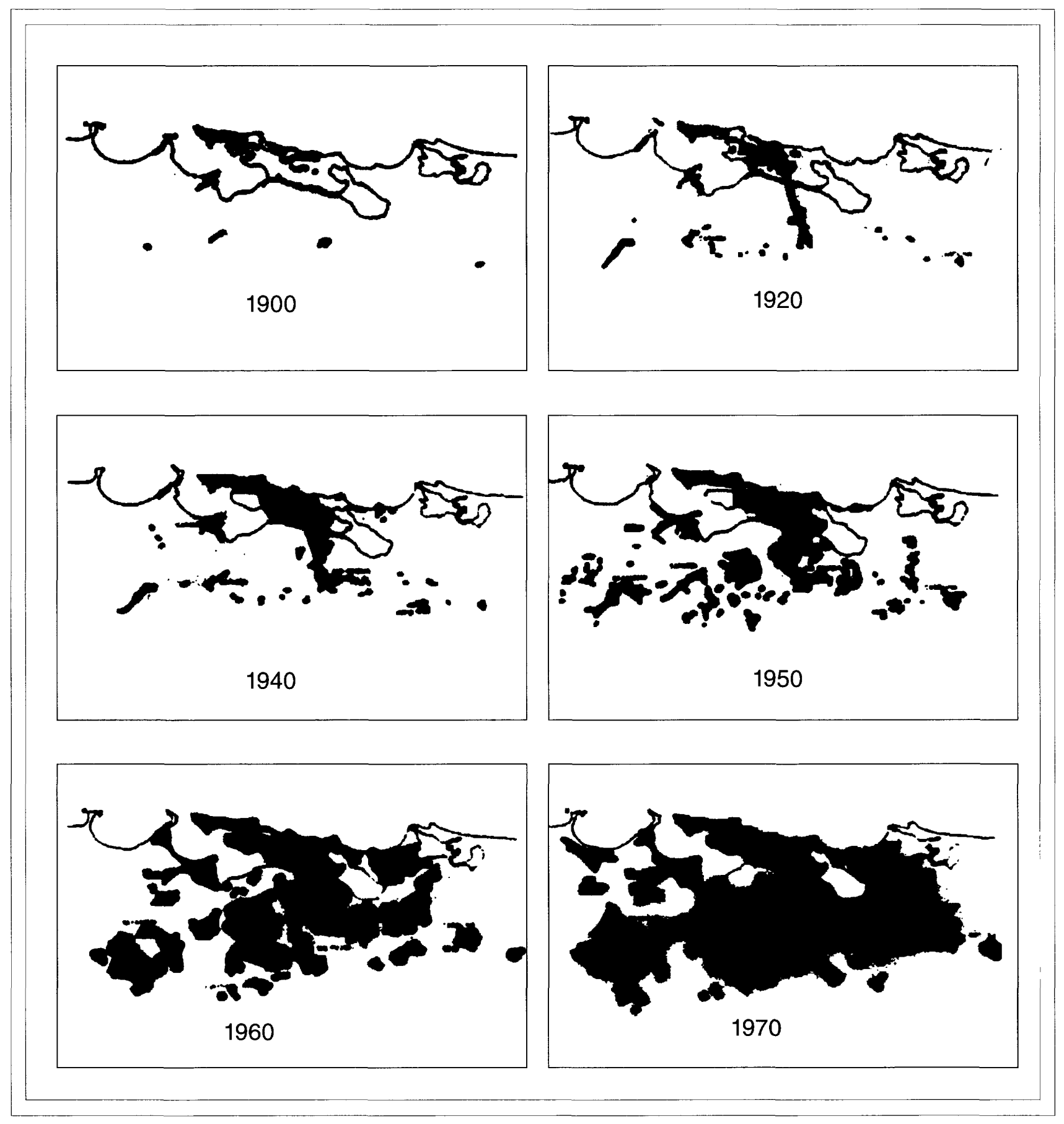

\section{EXPLANATION}

URBAN AREA

Figure 5. Progressive urbanization of the San Juan Metropolitan area from 1900 through 1970 (modified from Puerto Rico Planning Board, 1976). 


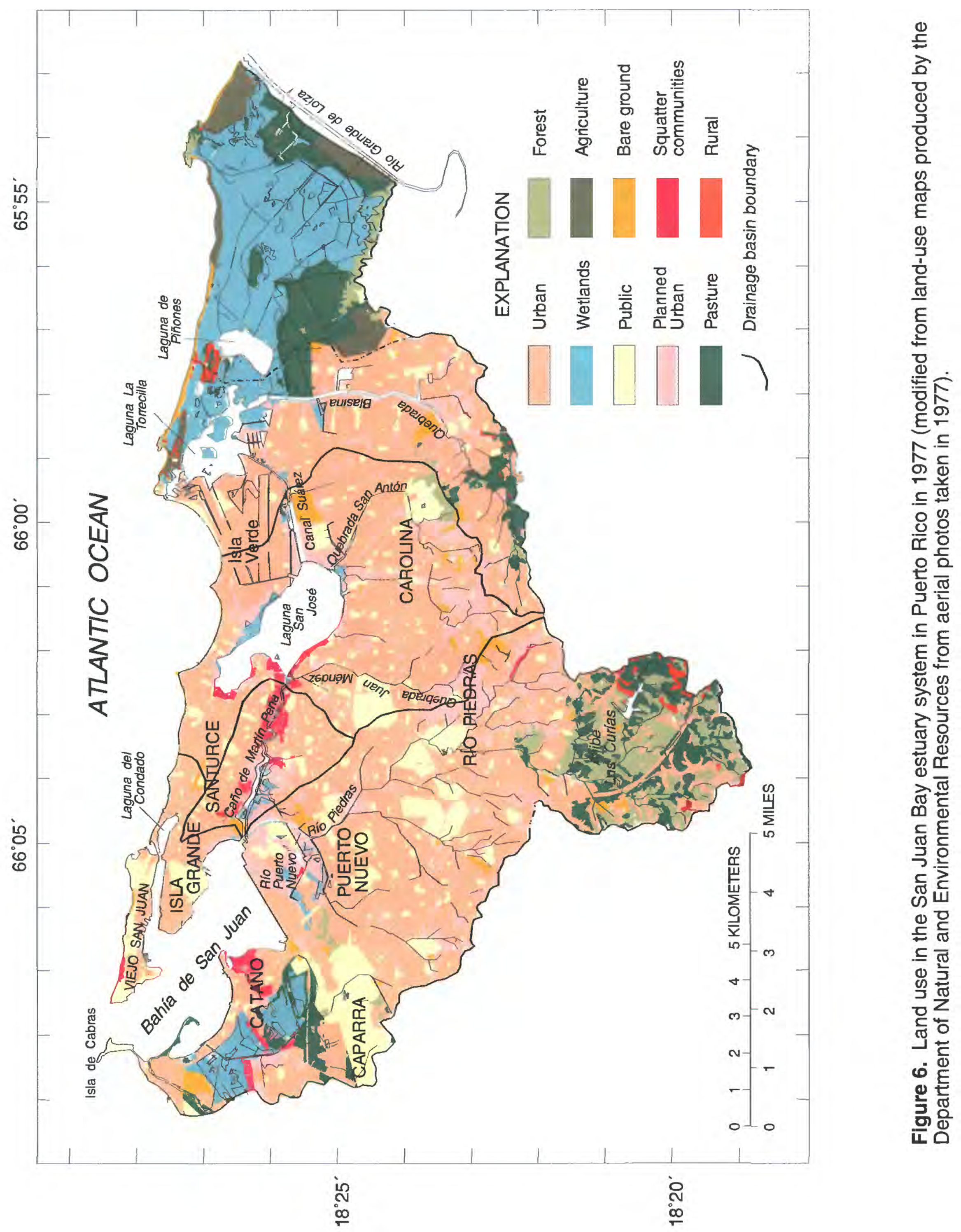


Table 1. Summary of the San Juan Bay estuary system study sampling plan including station types, field variables measured, and laboratory analyses

[The qualifier "exploratory" is used to describe stations where only general physical, inorganic, or biological variables were determined. As, arsenic; $\mathrm{Ba}$, barium; Cd, cadmium; Cr, chromium; Pb, lead; Hg, mercury; Se, selenium; PCB, polychlorinated biphenyl; PCN, polychlorinated naphthalene; SVOC, semi-volatile organic compound]

\begin{tabular}{|c|c|c|}
\hline Station type & Field observations & Laboratory analyses \\
\hline $\begin{array}{l}\text { Water-quality site-Surface water } \\
\text { sample from near top of water column } \\
\text { at } 15 \text { sites, once during a dry period } \\
\text { (March 1995), and once after a } \\
\text { significant runoff event (May 1995) }\end{array}$ & $\begin{array}{l}\text { Date, time, stage, and depth profiles for } \\
\text { temperature, specific conductance, } \\
\text { dissolved oxygen, and secchi depth. }\end{array}$ & $\begin{array}{l}\text { Turbidity, color, total suspended } \\
\text { solids, chlorophyll'a', fecal coliform } \\
\text { bacteria, ammonia, nitrate+nitrite, } \\
\text { nitrite, and orthophosphate. }\end{array}$ \\
\hline $\begin{array}{l}\text { Exploratory bottom sediment-quality } \\
\text { site-Surficial sediment sampled with } \\
\text { Ponar grab sampler at } 9 \text { sites (July } \\
\text { 1995) }\end{array}$ & $\begin{array}{l}\text { Same as water-quality sampling sites } \\
\text { plus the volume recovered, color, } \\
\text { general appearance and odor, and a } \\
\text { general description of vegetation and } \\
\text { infauna maintained on a } 2-\mathrm{mm} \text { sieve. }\end{array}$ & $\begin{array}{l}\text { Texture, total ammonia plus organic } \\
\text { nitrogen, total phosphorous, and } \\
\text { total carbon. }\end{array}$ \\
\hline $\begin{array}{l}\text { Detailed bottom sediment-quality } \\
\text { site-Core samples from regular } \\
\text { intervals at } 6 \text { sites-(first visit } \\
\text { December } 1994 \text { ) }\end{array}$ & $\begin{array}{l}\text { Same as exploratory sediment-sampling } \\
\text { sites plus water depth, length of } \\
\text { penetration, and percent recovery. }\end{array}$ & $\begin{array}{l}\text { Texture, total ammonia plus organic } \\
\text { nitrogen, total phosphorous, total } \\
\text { carbon, cesium-137, and lead- } 210 \text {. }\end{array}$ \\
\hline $\begin{array}{l}\text { Detailed sediment-quality } \\
\text { site-Second visit (July 1995): } \\
\text { Homogenized core samples from } \\
\text { three sections based on the results of } \\
\text { the radioisotope activity. The core } \\
\text { sections correspond approximately to } \\
\text { the following depositional periods: } \\
\text { 1925-49, 1950-74, and 1975-95. }\end{array}$ & $\begin{array}{l}\text { Same as exploratory sediment-sampling } \\
\text { sites plus water depth, length of } \\
\text { penetration, percent recovery }\end{array}$ & $\begin{array}{l}\text { Trace elements (As, } \mathrm{Ba}, \mathrm{Cd}, \mathrm{Cr}, \mathrm{Pb} \text {, } \\
\mathrm{Hg}, \mathrm{Se} \text { ), and } 17 \text { organochlorine } \\
\text { insecticides including total PCB's } \\
\text { and PCN's for all sections. In } \\
\text { addition, } 52 \text { SVOC's and oil and } \\
\text { grease for the } 1975-95 \text { section, and } \\
4 \text { chlorophenoxy-acid herbicides } \\
\text { for the 1950-74 section. }\end{array}$ \\
\hline
\end{tabular}

Available information on bathymetry and previous water and sediment sampling was used to locate the sampling sites for this study. Sediment and water quality sampling sites were distributed throughout the tidally influenced part of the estuary system from the mouth of the Bahía de San Juan to the drainage channels of Bosque Estatal de Piñones. No sampling was conducted at Laguna del Condado, in the rivers, or in the nearshore marine waters. The sites sampled in the synoptic sampling of quality of water and bottom sediments are indicated in figures 7,8 , and 9 .

The sampling program consisted of two synoptic surveys of general water quality conducted in March (dry weather) and May (wet weather) of 1995. Bottom sediments obtained in core samples were analyzed for texture, nutrients (ammonia plus organic nitrogen, total phosphorus), and total carbon at the detailed sediment quality sites in December 1994 and at exploratory sediment quality sites sampled with a Ponar grab sampler (surficial bottom sediment sample) in July 1995. Analytical results of the activity of the radioisotope Cs-137 measured in the cores obtained in December 1994 were used to establish sediment deposition rates at each sample location and determine sediment depth intervals corresponding to the discrete time intervals of 1925-49, 1950-74, and 1975-95. In July 1995, depth integrated sampling of sediment quality was conducted at the six detailed sediment sites to relate the concentration of selected constituents to the period of deposition. In all, 20 sites were sampled during this study; 10 being common to both sediment and water quality with 5 sampled for water quality only and 5 sampled for sediment quality only (table 2). 


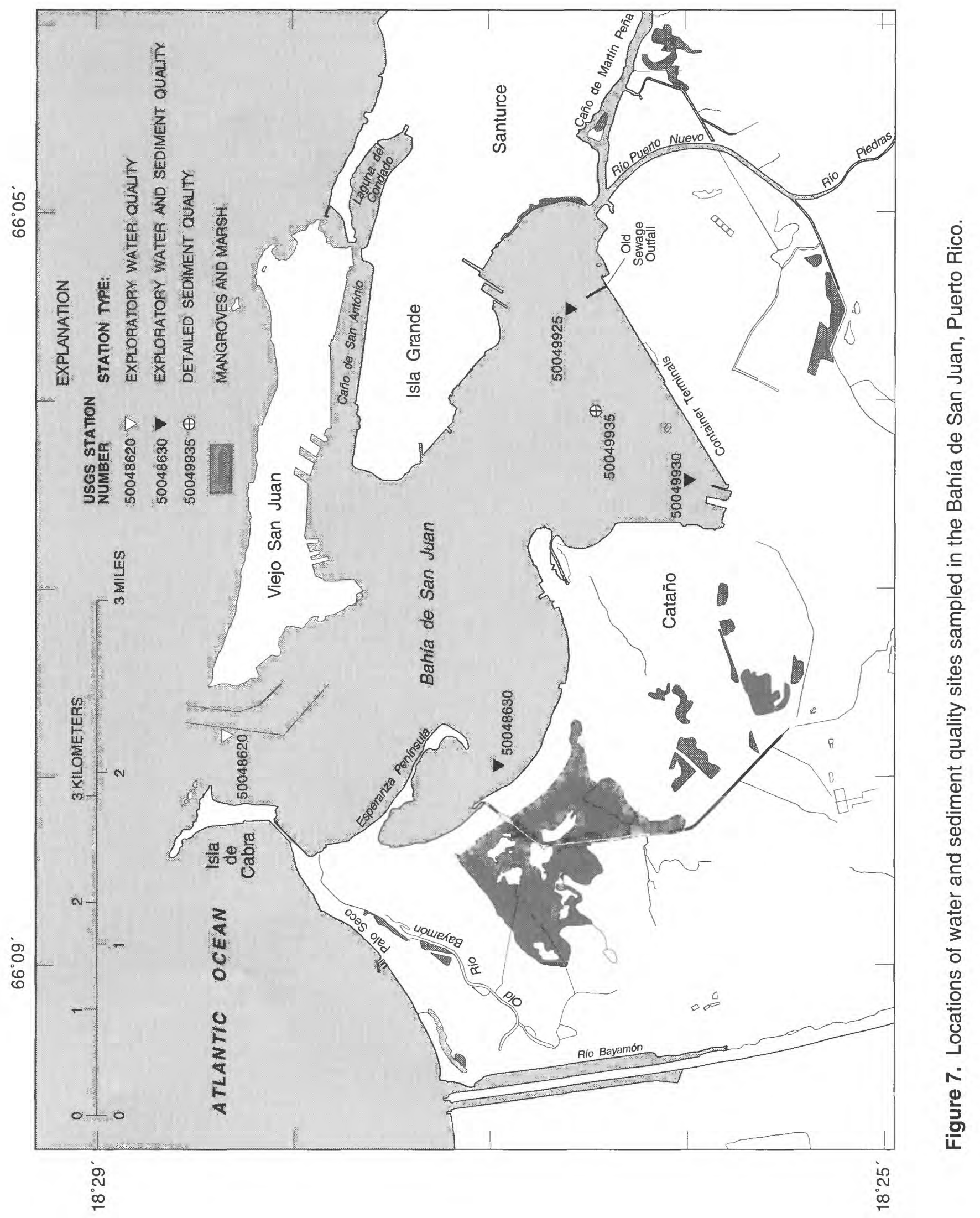




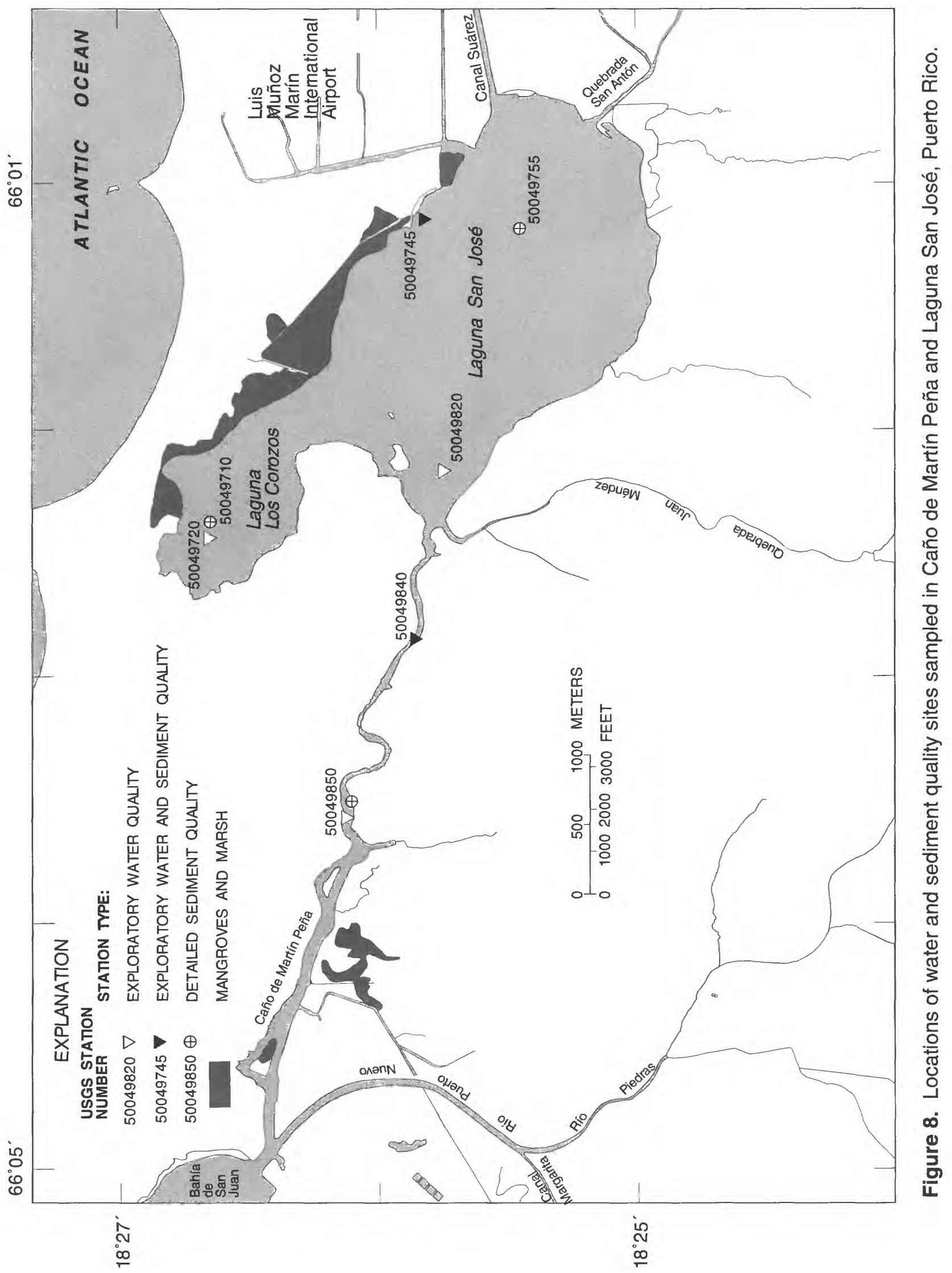




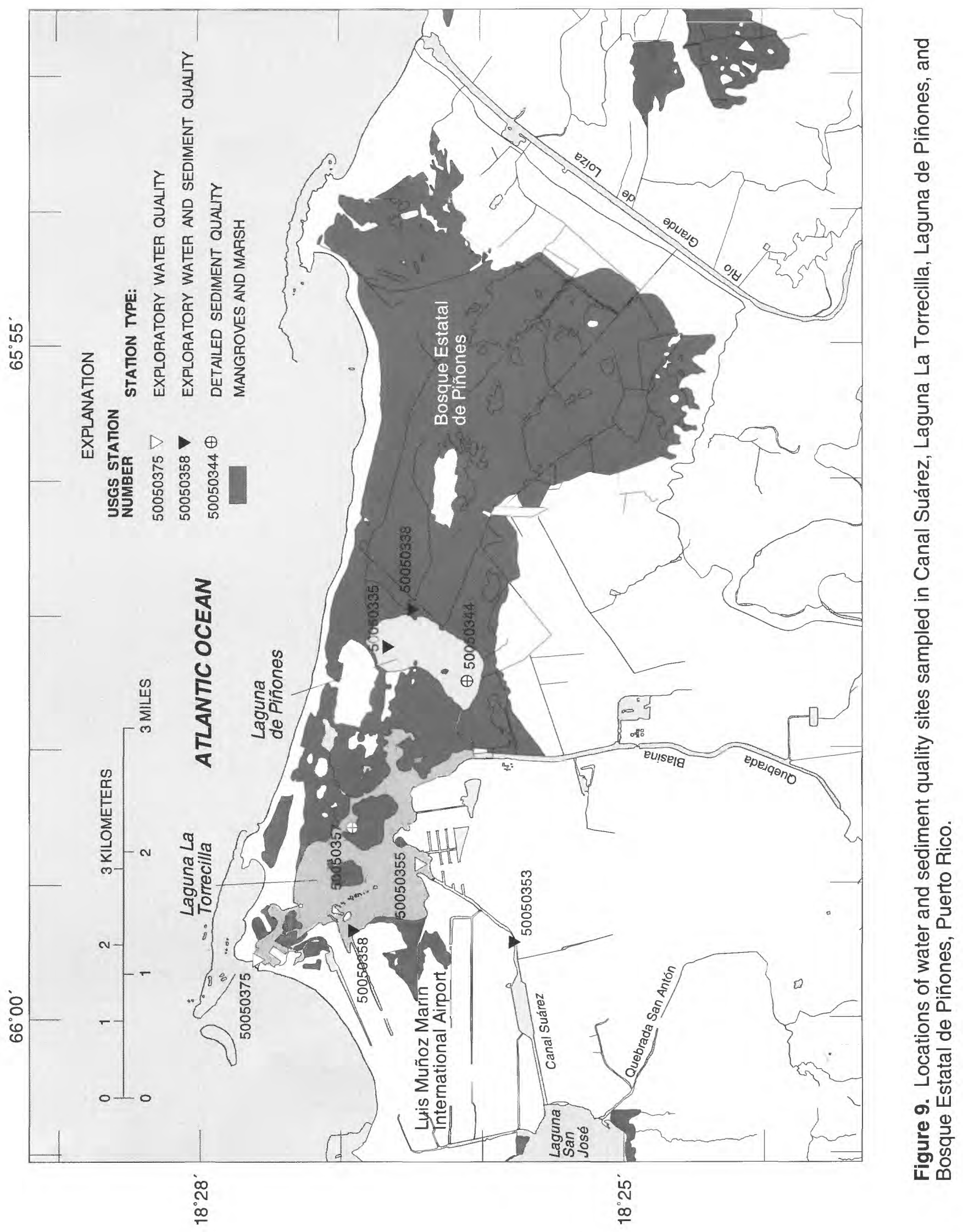


Table 2. Water depth locations and station types of sampling sites in the San Juan Bay estuary system, Puerto Rico

[Abbreviations for station types: QW, Water quality; SED-I, Exploratory sediment quality; SED-II, Detailed sediment quality. Datum for geographic coordinates is the Puerto Rico Datum, 1940 adjustment]

\begin{tabular}{|c|c|c|c|c|c|}
\hline $\begin{array}{l}\text { USGS station } \\
\text { number }\end{array}$ & Name & $\begin{array}{l}\text { Water depth } \\
\text { (meters) }\end{array}$ & Latitude (N) & Longitude (W) & Station type \\
\hline 50048620 & San Juan Bay \#1 & 7.5 & $18^{\circ} 28^{\prime} 22^{\prime \prime}$ & $66^{\circ} 07^{\prime} 41^{\prime \prime}$ & QW \\
\hline 50048630 & San Juan Bay \#2 & 2.3 & $18^{\circ} 26^{\prime} 52.1^{\prime \prime}$ & $66^{\circ} 07^{\prime} 46.5^{\prime \prime}$ & QW, SED-I \\
\hline 50049930 & San Juan Bay \#4 & 11.8 & $18^{\circ} 26^{\prime} 01.1^{\prime \prime}$ & $66^{\circ} 06^{\prime} 24.4^{\prime \prime}$ & QW, SED-I \\
\hline 50049935 & SJN600 & 3.7 & $18^{\circ} 26^{\prime} 35.4^{\prime \prime}$ & $66^{\circ} 06^{\prime} 14.0^{\prime \prime}$ & SED-II \\
\hline 50049925 & San Juan Bay Pylon \#5 & 3.1 & $18^{\circ} 26^{\prime} 30.5^{\prime \prime}$ & $66^{\circ} 05^{\prime} 24.3^{\prime \prime}$ & QW, SED-I \\
\hline 50049850 & MPN500 & 0.7 & $18^{\circ} 26^{\prime} 07.4^{\prime \prime}$ & $66^{\circ} 03^{\prime} 29.7^{\prime \prime}$ & QW, SED-II \\
\hline 50049840 & Martín Peña at Barbosa & 0.8 & $18^{\circ} 25^{\prime} 51.9^{\prime \prime}$ & $66^{\circ} 02^{\prime} 51.1^{\prime \prime}$ & QW, SED-I \\
\hline 50049820 & San José Lagoon \#2 & 1.0 & $18^{\circ} 25^{\prime} 50^{\prime \prime}$ & $66^{\circ} 02^{\prime} 12^{\prime \prime}$ & QW \\
\hline 50049720 & San José Lagoon \#3 & 1.5 & $18^{\circ} 26^{\prime} 40^{\prime \prime}$ & $66^{\circ} 02^{\prime} 26^{\prime \prime}$ & QW \\
\hline 50049710 & CRZ400 & 2.0 & $18^{\circ} 26^{\prime} 40.0^{\prime \prime}$ & $66^{\circ} 02^{\prime} 22.0^{\prime \prime}$ & SED-II \\
\hline 50049755 & SJS300 & 1.9 & $18^{\circ} 25^{\prime} 21.6^{\prime \prime}$ & $66^{\circ} 01^{\prime} 10.6^{\prime \prime}$ & SED-II \\
\hline 50049745 & Laguna Gardens & 4.0 & $18^{\circ} 25^{\prime} 49.0^{\prime \prime}$ & $66^{\circ} 01^{\prime} 04.9^{\prime \prime}$ & QW, SED-I \\
\hline 50050353 & Suarez Canal at Hwy 26 & 1.0 & $18^{\circ} 25^{\prime} 46.4^{\prime \prime}$ & $66^{\circ} 59^{\prime} 28.0^{\prime \prime}$ & QW, SED-I \\
\hline 50050355 & Torrecilla Lagoon \#3 & 2.2 & $18^{\circ} 26^{\prime} 37^{\prime \prime}$ & $66^{\circ} 588^{\prime \prime}$ & QW \\
\hline 50050358 & SJ VORTAC & 0.8 & $18^{\circ} 26^{\prime} 56.8^{\prime \prime}$ & $66^{\circ} 59^{\prime} 20.8^{\prime \prime}$ & QW, SED-I \\
\hline 50050375 & Torrecilla Lagoon \#1 & 4.0 & $18^{\circ} 27^{\prime} 36^{\prime \prime}$ & $66^{\circ} 59^{\prime} 34^{\prime \prime}$ & QW \\
\hline 50050357 & TRC200 & 0.9 & $18^{\circ} 26^{\prime} 55.1^{\prime \prime}$ & $66^{\circ} 58^{\prime} 35.0^{\prime \prime}$ & SED-II \\
\hline 50050344 & PNN100 & 0.9 & $18^{\circ} 26^{\prime} 06.7^{\prime \prime}$ & $66^{\circ} 57^{\prime} 29.8^{\prime \prime}$ & SED-II \\
\hline 50050335 & Piñones \#3 & 1.0 & $18^{\circ} 26^{\prime} 42.6^{\prime \prime}$ & $66^{\circ} 57^{\prime} 13.3^{\prime \prime}$ & QW, SED-I \\
\hline 50050338 & Piñones Drainage Canal & 0.4 & $18^{\circ} 26^{\prime} 28.6^{\prime \prime}$ & $66^{\circ} 56^{\prime} 53.8^{\prime \prime}$ & QW, SED-I \\
\hline
\end{tabular}

\section{Water Quality and Bottom Sediment Analyses}

All water and sediment samples were collected using standard USGS field sampling techniques (Ward and Harr, 1990; Britton and Greeson, 1987) (table 3). All sample bottles and preservatives were provided by the USGS-National Water Quality Laboratory in Arvada, Colorado, or by the USGS Water Quality Laboratory in Ocala, Florida. Special care to avoid contamination was observed at all times while sampling, chilling, and shipping. The order of sampling stations proceeded from the uncontaminated stations to the most contaminated stations.

Water-quality samples were collected near the surface of the water column. Samples to be analyzed for dissolved nitrogen species and phosphorus were filtered through a $0.45-\mu \mathrm{m}$ pore-size membrane 142 $\mathrm{mm}$ in diameter (Ward and Harr, 1990, p. 51) with a portable peristaltic pump. The pumping filter assembly was thoroughly cleaned with a nonphosphate laboratory detergent and rinsed with tap water followed by distilled or demineralized water before transportation to the field. New filters were used at each site. After sample processing, the tygon tubing was first backflushed and then rinsed with deionized water.

On-site sample processing included Winkler titration for dissolved oxygen, membrane vacuum filtration for fecal coliform, and glass-fiber vacuum filtration for chlorophyll' $a$ ' and ' $b$ '. For chlorophyll determinations, half of the sample was filtered, the filter was replaced, and the remaining sample filtered. Each filter was rolled and wrapped in aluminum foil, then placed in an amber sample bottle of the same type used for sampling volatile organic compounds. The bottles were wrapped in bubble-wrap and transported to the laboratory on dry ice.

Each batch of samples shipped to laboratories for analyses was tracked with a chain of custody record to document the location, number and kinds of sample containers, and condition of the samples when shipped and upon arrival. All transfers of custody showed who relinquished and who received the samples. 
Table 3. Analytes, sample quantities, preservation techniques, and maximum holding times

[mL, milliliters; g, grams; ${ }^{\circ} \mathrm{C}$, degrees Celsius; mm, millimeter; $\mathrm{Hg}$, mercury; PCB, polychlorinated biphenyl; PCN, polychlorinated naphthalene]

\begin{tabular}{|c|c|c|c|c|c|}
\hline $\begin{array}{l}\text { Sample } \\
\text { matrix }\end{array}$ & Analyte/Parameter & $\begin{array}{l}\text { Sample } \\
\text { quantity }\end{array}$ & Sample container & $\begin{array}{l}\text { Method of sample } \\
\text { preservation }\end{array}$ & $\begin{array}{l}\text { Maximum holding } \\
\text { time }\end{array}$ \\
\hline Water & Turbidity & $125 \mathrm{~mL}$ & $\begin{array}{l}\text { Polyethylene bottle, } \\
\text { field rinsed }\end{array}$ & $\begin{array}{l}\text { Use unfiltered sample to rinse } \\
\text { bottles. }\end{array}$ & 48 hours \\
\hline Water & $\begin{array}{l}\text { Total Suspended } \\
\text { Solids }\end{array}$ & $500 \mathrm{~mL}$ & $\begin{array}{l}\text { Polyethylene bottle, } \\
\text { field rinsed }\end{array}$ & $\begin{array}{l}\text { Use unfiltered sample to rinse } \\
\text { bottles. }\end{array}$ & 7 days \\
\hline Water & Chlorophyll'a' & 2 filters & Glass vial & $\begin{array}{l}\text { Collect on glass filter. Record } \\
\text { volume filtered. Place filter in } \\
\text { vial and wrap in aluminum } \\
\text { foil. Freeze with dry ice and } \\
\text { ship expeditiously. }\end{array}$ & $\begin{array}{l}\text { Stored at }-14^{\circ} \mathrm{C} \\
\text { upon arrival at lab. } \\
\text { Analyze within } 14 \\
\text { days }\end{array}$ \\
\hline Water & Nutrients & $125 \mathrm{~mL}$ & $\begin{array}{l}\text { Brown polyethylene } \\
\text { bottle, field rinsed }\end{array}$ & $\begin{array}{l}\text { Filter through } 0.45-\mu \mathrm{m} \text {; use } \\
\text { filtered sample to rinse } \\
\text { containers, chill and } \\
\text { maintain at } 4^{\circ} \mathrm{C} \text {; ship as soon } \\
\text { as possible. }\end{array}$ & 48 hours \\
\hline Sediment & Texture & $50 \mathrm{~g}$ & $\begin{array}{l}\text { Polypropylene bottle, } \\
\text { wide-mouth }\end{array}$ & $\begin{array}{l}\text { Untreated, seal well to } \\
\text { prevent desiccation. }\end{array}$ & 60 days \\
\hline Sediment & Nutrients & $10 \mathrm{~g}$ & $\begin{array}{l}\text { Polypropylene bottle, } \\
\text { wide-mouth }\end{array}$ & $\begin{array}{l}\text { Field sieve through a plastic } \\
2 \text {-mm sieve using native } \\
\text { water. Preserve at } 4^{\circ} \mathrm{C} .\end{array}$ & 28 days \\
\hline Sediment & Trace elements & $10 \mathrm{~g}$ & $\begin{array}{l}\text { Polyethylene bottle, } \\
\text { wide-mouth }\end{array}$ & $\begin{array}{l}\text { Field sieve through a plastic } \\
\text { 2-mm sieve using native } \\
\text { water. Preserve at } 4^{\circ} \mathrm{C} \text {. }\end{array}$ & $\begin{array}{l}\mathrm{Hg}-28 \text { days; } \\
\text { Others - } 6 \text { months }\end{array}$ \\
\hline Sediment & $\begin{array}{l}\text { Organochlorine } \\
\text { pesticides with gross } \\
\text { PCB's and PCN's }\end{array}$ & $200 \mathrm{~g}$ & $\begin{array}{l}\text { Glass bottle, wide- } \\
\text { mouth. Bottle baked at } \\
450^{\circ} \mathrm{C} \text { by laboratory. }\end{array}$ & $\begin{array}{l}\text { Do not rinse bottle. Chill and } \\
\text { maintain at } 4^{\circ} \mathrm{C} \text {; ship as soon } \\
\text { as possible. }\end{array}$ & $\begin{array}{l}14 \text { days until } \\
\text { extraction, } 40 \text { days } \\
\text { after extraction }\end{array}$ \\
\hline Sediment & $\begin{array}{l}\text { Semi-volatile organic } \\
\text { compounds, oil and } \\
\text { grease }\end{array}$ & $200 \mathrm{~g}$ & $\begin{array}{l}\text { Glass bottle, wide- } \\
\text { mouth. Bottle baked at } \\
450^{\circ} \mathrm{C} \text { by laboratory. }\end{array}$ & $\begin{array}{l}\text { Do not rinse bottle. Chill and } \\
\text { maintain at } 4^{\circ} \mathrm{C} \text {; ship as soon } \\
\text { as possible. }\end{array}$ & $\begin{array}{l}14 \text { days until } \\
\text { extraction, } 40 \text { days } \\
\text { after extraction }\end{array}$ \\
\hline Sediment & $\begin{array}{l}\text { Chlorophenoxy-acid } \\
\text { Herbicides }\end{array}$ & $200 \mathrm{~g}$ & $\begin{array}{l}\text { Glass bottle, wide- } \\
\text { mouth. Bottle baked at } \\
450^{\circ} \mathrm{C} \text { by laboratory. }\end{array}$ & $\begin{array}{l}\text { Do not rinse bottle. Chill and } \\
\text { maintain at } 4{ }^{\circ} \mathrm{C} \text {; ship as soon } \\
\text { as possible. }\end{array}$ & $\begin{array}{l}14 \text { days until } \\
\text { extraction, } 40 \text { days } \\
\text { after extraction }\end{array}$ \\
\hline
\end{tabular}


Field reconnaissance and initial bottom sediment coring operations were conducted December 12-16, 1994. Sites were located using a global positioning system (GPS) receiver. Once on-site, the boat was two- or three-point anchored. Differential GPS corrections were received at three of the six coring sites (Laguna San José, Laguna Los Corozos, and Bahía de San Juan) resulting in a positional accuracy within $10 \mathrm{~m}$. Differential GPS corrections were not available at the Laguna de Piñones coring site, the Laguna La Torrecilla site, or the Caño de Martín Peña site. However, positional accuracy comparable to the sites with differential GPS corrections was provided at these three nearshore sites by photographing coastal landmarks located at various azimuths. During subsequent sampling trips it was determined all sites could be accurately relocated by referring to aligned landmarks observable in the photographs. Even the sites farthest from shore, in Laguna San José and Bahía de San Juan, could be relocated to within $30 \mathrm{~m}$ as verified in subsequent trips with simultaneous differential GPS observations.

During the December 1994 reconnaissance, six sites were cored to document variations of grain size, total Kjeldahl nitrogen, total phosphorus, total carbon, and the radioisotopes of Cs-137 and lead-210 (Pb-210) with depth. Variations in the activity of the radioisotopes $\mathrm{Cs}-137$ and $\mathrm{Pb}-210$ were used to infer average sedimentation rates at the sites. The coring device used consisted of a 4"-diameter, 3-m-long PVC pipe, open at the bottom and coupled to a check valve and a string of 1 "-diameter pipes at the top. After recording the water depth, the PVC pipe was lowered to the bottom at the end of the string of 1 "-diameter pipes. Air and water were allowed to vent through a check-valve as the corer was pushed into the soft sediments. Once rejection was encountered (the corer could not be pushed further into the sediments), the corer was extracted vertically. The bottom of the core was covered while still below the water surface and the core was brought onboard in a vertical position. Once onboard, the depth of penetration, as marked by the mud line, was measured, the reducing bell was removed and the water above the top sediment layer extracted with a hand pump with an inverted nozzle. After a piston and push-rod were inserted, the core was laid horizontally and extruded into a clean plastic trough where the core was photographed, described, and sampled.
Sediments were sampled at 15 sites. Of these 15 sites, 9 were designated as exploratory sedimentquality sites where surficial sediments were sampled for grain size, nitrogen and phosphorous content, and total carbon content. The exploratory sediment-quality sites were selected to correspond to water quality stations or to provide baseline data in an area that had not been previously sampled. The remaining six sites were sampled with a coring device to document variations of grain size, nitrogen and phosphorous content, total carbon content, radioisotopes, and contaminants with depth. The coring sites were chosen in areas of fine-grained sediment deposits and away from dredged areas. In addition, the coring sites were located in the central areas of water bodies to document contamination introduced from various input points around the perimeter of the water body and not just the influence of a local point source.

The sediment texture, or grain-size distribution, of the sediments was analyzed by Larry Poppe at the USGS Sediment laboratory in Woods Hole, Massachusetts. Moist samples from the field were wet sieved through a $62.5-\mu \mathrm{m}$ sieve to separate the sand and gravel from silts and clays. Floating material, organic flock, and whole shells were removed from the sand and gravel fraction before processing with a stack of sieves as described by Folk (1980). The silt and clay fraction was analyzed using a Coulter counter as described by Poppe and others (1985). The salinity of the interstitial waters of the bottom sediments needed to adjust the results of the Coulter counter analysis was assumed to be 25 parts per thousand (ppt).

To obtain enough material for radioisotope analysis, three cores from each site were recovered and homogenized in 5-cm intervals. The only exception was the Martín Peña site, where the sedimentation rates were expected to be higher and so only two cores were obtained and sampled in $10-\mathrm{cm}$ intervals. Each of the 2 or 3 replicate cores was photographed, then sectioned. Composites of the same sampling interval for each core were homogenized using a stainless steel spatula in a stainless steel bucket and stored in new plastic ziplock bags identified with site, date, time, and sampling interval. Splits of the homogenized sampled were taken for radioisotope and grain-size analyses. Samples for nutrient and carbon content were first passed through a 2-mm stainless steel sieve. Shell material retained on the sieve was archived for later identification. Samples for 
radioisotopes and grain size were maintained at ambient temperature whereas those for nutrient and carbon content were stored at $4{ }^{\circ} \mathrm{C}$ either on ice or in a local laboratory refrigerator prior to packing and shipping to the analytical laboratory.

Sampling for grain size, trace elements, and organic compounds by time interval was done in July 1995. Coring operations were identical to that of December 1994. Once extruded into the clean plastic trough, the core sample was split longitudinally with a stainless steel spatula. Samples for organic compounds were obtained from the interior areas with the spatula and transferred to baked, wide-mouth glass jars provided by the National Water Quality Laboratory. Samples to be analyzed for trace elements were also extracted from the interior of the core using a plastic spatula, sieved through a 2-mm polypropylene screen, and transferred to polypropylene containers for storage and shipment to the laboratory. Equipment was washed with laboratory soap and rinsed with native water between sampling sites. Equipment was rinsed with native water between individual core samples. Sampling proceeded from the least contaminated sites to the most contaminated sites and from the bottom to the top for each core.

Water and sediment samples were analyzed using standard methods when available (table 4, 5). Most of the methods are USGS methods identified with a three part identification such as I-3680-85. The initial letter identifies the field of analysis: I (inorganic), O (organic), or B (Biological). The four digits in the middle specify the analytical method,

Table 4. Analytical procedures for exploratory designated water-quality samples

[NTU, nephelometric turbidity units; mg/L, milligrams per liter; col/100 mL, colonies per 100 milliliters; mg/L, micrograms per liter; N/A, not available]

\begin{tabular}{|c|c|c|c|c|c|c|}
\hline Parameter & Units & $\begin{array}{l}\text { Minimum } \\
\text { reporting } \\
\text { limit }\end{array}$ & Methodology 1 & $\begin{array}{l}\text { Estimated } \\
\text { Accuracy } \\
\text { (percent } \\
\text { recovery) }\end{array}$ & $\begin{array}{c}\text { Estimated } \\
\text { Precision } \\
\text { (relative } \\
\text { percent } \\
\text { difference) }\end{array}$ & Laboratory \\
\hline Turbidity & NTU & 0.1 & Nephelometric I-3860-85 & N/A & N/A & $\begin{array}{l}\text { USGS Water Quality } \\
\text { Laboratory, Ocala, FL }\end{array}$ \\
\hline $\begin{array}{l}\text { Fecal coliform } \\
\text { bacteria }\end{array}$ & $\begin{array}{l}\mathrm{col} / 100 \\
\mathrm{~mL}\end{array}$ & 1 & Membrane-filter B-0050-85 & N/A & N/A & $\begin{array}{l}\text { USGS Water Quality } \\
\text { Lab, San Juan, PR }\end{array}$ \\
\hline Chlorophyll' a' & $\mu \mathrm{g} / \mathrm{L}$ & 0.1 & $\begin{array}{l}\text { High-pressure liquid } \\
\text { chromatography B-6530-85 }\end{array}$ & $\mathrm{N} / \mathrm{A}$ & $\mathrm{N} / \mathrm{A}$ & $\begin{array}{l}\text { USGS National Water } \\
\text { Quality Laboratory, } \\
\text { Denver, CO }\end{array}$ \\
\hline $\begin{array}{l}\text { Nitrate plus } \\
\text { nitrite, dissolved } \\
\text { as } \mathrm{N}\end{array}$ & $\mathrm{mg} / \mathrm{L}$ & .02 & $\begin{array}{l}\text { Colorimetric-cadmium } \\
\text { reduction-diazotization } \\
\text { I- } 2545-90\end{array}$ & $91-109$ & $<20$ & $\begin{array}{l}\text { USGS Water Quality } \\
\text { Laboratory, Ocala, FL }\end{array}$ \\
\hline $\begin{array}{l}\text { Nitrite, } \\
\text { dissolved as } \mathrm{N}\end{array}$ & $\mathrm{mg} / \mathrm{L}$ & .01 & $\begin{array}{l}\text { Colorimetric-diazotization } \\
\text { I- } 2540-90\end{array}$ & $91-109$ & $<20$ & $\begin{array}{l}\text { USGS Water Quality } \\
\text { Laboratory, Ocala, FL }\end{array}$ \\
\hline $\begin{array}{l}\text { Orthophosphate, } \\
\text { dissolved - as } \mathbf{P}\end{array}$ & $\mathrm{mg} / \mathrm{L}$ & .01 & $\begin{array}{l}\text { Colorimetric- } \\
\text { phosphomolybdate } \\
\text { technique I-2601-90 }\end{array}$ & $91-109$ & $<20$ & $\begin{array}{l}\text { USGS Water Quality } \\
\text { Laboratory, Ocala, FL }\end{array}$ \\
\hline
\end{tabular}

\footnotetext{
${ }^{1}$ The initial letter of the method identification code identifies the field of analysis: I (inorganic), or B (Biological). The four digits in the middle specify the analytical method, whereas the last two digits identify the year that the method was last revised. These methods are detailed in USGS reports edited by Fishman (1993) (inorganic and organic), Fishman and Friedman (1989) (inorganic), and Britton and Greeson (1987) (field techniques and microbiological analysis).
} 
whereas the last two digits identify the year that the method was last revised. These methods are detailed in USGS reports edited by Fishman (1993) (inorganic and organic), Fishman and Friedman (1989) (inorganic), Wershaw and others (1987) (organics), and Britton and Greeson (1987) (field techniques and microbiological analysis). Sediment grain-size and radioisotope activities were measured using nonstandard methods discussed in detail below.

\section{Bottom Sediment Cores and Sedimentation Rates}

Estimation of sedimentation rates at selected sites in the estuary system was attempted using two different radioisotopes, $\mathrm{Cs}-137$ and $\mathrm{Pb}-210$ (McHenry and others, 1980; Durham and Joshi, 1980). Cs-137 is a by-product of atmospheric nuclear-bomb testing with a half-life of 30 years. The radioisotope does not occur naturally and is distributed throughout the atmosphere after sub-aerial detonations, eventually settling out on the surface of the Earth where it binds firmly to sediment particles. Fluvial processes transport the sediment and adsorbed Cs- 137 through the drainage system to depositional areas. Strata in the sediments with high Cs-137 activity correlate to periods of increased activity of sub-aerial nuclear detonations. The most distinct time horizons usually identified are 1952, the first year of significant nuclear testing and subsequent fallout of Cs-137, and 1963, the most active year with frequent testing by both the United States and the former Soviet Union. The peaks may lag by a year or two after 1963 if there is any delay in the fluvial transport from the land surface to the depositional site (Crusius and Anderson, 1995).

In contrast to the rapidly changing fluxes of Cs-137, the Pb-210 method depends instead on a constant flux of radon gas from the Earth's surface (Krishnaswami and others, 1971). Pb-210, with a halflife of 22.3 years, is a member of the Uranium-238 decay series. Natural U-238 decays eventually to radon-222, a radioactive gas with a half-life of 3.8 days. In the atmosphere, radon-222 decays to $\mathrm{Pb}-210$ and precipitates. That part of $\mathrm{Pb}-210$ reaching water bodies is quickly scavenged from the water column by adsorbtion to particulate matter and settles to the bottom. Where the sedimentation rate and the $\mathrm{Pb}-210$ flux are constant, the age of the sediment can be determined by assuming the excess $\mathrm{Pb}-210$ activity decreases downcore by a factor of 2 every 22.3 years. The excess activity is the total activity minus the activity explained by the decay of in-situ radium-226,

Table 5. Analytical procedures for exploratory sediment-quality samples

$[\mathrm{mg} / \mathrm{kg}$, milligrams per kilogram - equivalent to parts per million; $\mathrm{g} / \mathrm{kg}$, grams per kilogram - equivalent to parts per thousand; mm, millimeter]

\begin{tabular}{|c|c|c|c|c|}
\hline Parameter & Units & $\begin{array}{l}\text { Minimum } \\
\text { reporting limit }\end{array}$ & Methodology 1 & Comments \\
\hline Texture & $\begin{array}{l}\text { Weight percent } \\
\text { finer than }\end{array}$ & 0.1 & $\begin{array}{l}\text { Poppe and others, 1985; } \\
\text { Guy, } 1969\end{array}$ & $\begin{array}{l}\text { Combination of sieve, and Coulter counter } \\
\text { analysis. Assume salinity of interstitial } \\
\text { water to be } 25 \text { part per thousand. }\end{array}$ \\
\hline $\begin{array}{l}\text { Total ammonia }+ \\
\text { organic nitrogen }\end{array}$ & $\mathrm{mg} / \mathrm{kg}$ & 10.0 & $\begin{array}{l}\text { Titrimetry, digestion- } \\
\text { distillation I-5553-91 }\end{array}$ & $\begin{array}{l}\text { Analyze only portion passing through } 2-\mathrm{mm} \\
\text { sieve. }\end{array}$ \\
\hline Total phosphorus & $\mathrm{mg} / \mathrm{kg}$ & 40 & $\begin{array}{l}\text { Colorimetry, } \\
\text { phosphomolybdate } \\
\text { I- } 6600-88\end{array}$ & $\begin{array}{l}\text { Analyze only portion passing through } 2-\mathrm{mm} \\
\text { sieve. Range from } 40 \text { to } 4,000 \mathrm{mg} / \mathrm{kg}\end{array}$ \\
\hline Total carbon & $\mathrm{g} / \mathrm{kg}$ & 0.1 & $\begin{array}{l}\text { Dry weight, induction } \\
\text { furnace, } 0-5101-83\end{array}$ & $\begin{array}{l}\text { Analyze only portion passing through } 2-\mathrm{mm} \\
\text { sieve. }\end{array}$ \\
\hline
\end{tabular}

\footnotetext{
1 The initial letter of the method identification code identifies the field of apalysis: I (inorganic) or O (organic). The 4 digits in the middle specify the analytical method, whereas the last two digits identify the year that the method was last revised. These methods are detailed in USGS reports edited by Fishman (1993) (inorganic and organic), Fishman and Friedman (1989) (inorganic), and Wershaw and others (1987) (organics).
} 
another parent radioisotope of $\mathrm{Pb}-210$. Both the $\mathrm{Cs}-137$ and $\mathrm{Pb}-210$ dating techniques depend on the fundamental assumption that the radionuclides are immobile once deposited in the sediment. Therefore, the results will be affected by any bioturbation or gaseous diffusion which may be active at the site. In addition, the $\mathrm{Pb}-210$ results can be complicated if excessive radium-226 is present. Cs-137 and $\mathrm{Pb}-210$ activities in the bottom sediments were determined using gamma counting by Dr. Sherwood McIntyre, at the United States Department of Agriculture's National Agricultural Water Quality Laboratory in Durant, Oklahoma. The scintillators were calibrated using reference materials obtained from the National Institute of Standards and Technology. Low activity levels for Cs-137 were anticipated for the estuarine coring sites because of the limited drainage area and dilution of the terrigenous sediments by organic debris and carbonate skeletal grains. Therefore, Dr. McIntyre used extended counting periods to reduce the minimum reporting level to 1 milliBecquerel per gram.

The radioisotope activities of Cs-137 and $\mathrm{Pb}-210$ were measured for regularly spaced samples recovered from sites cored in December 1994. Sample spacing was $5 \mathrm{~cm}$ for all cores except for the core from the Caño de Martín Peña site (MPN500), where a $10-\mathrm{cm}$ spacing was used because of the expected high sedimentation rate. The Cs- 137 activities were used to estimate average sedimentation rates at each site. Laboratory results for $\mathrm{Pb}-210$ indicated that the activity levels of $\mathrm{Pb}-210$ were inconclusive for estimating sedimentation rates. The activity of $\mathrm{Pb}-210$ was found not to decrease monotonically downward from the top of the core, a requisite condition for calculation of age dates with this radioisotope.

Sediment cores from the six sites were divided into intervals representing the time periods $1925-49$, 1950-74, and 1975-95, based on the sedimentation rates estimated using the Cs- 137 results. A homogenized sample from each interval was analyzed for 17 organochlorine compounds including total PCB's and PCN's, and seven trace elements (As, Ba, $\mathrm{Cd}, \mathrm{Cr}, \mathrm{Pb}, \mathrm{Hg}$, and $\mathrm{Se}$ ). The homogenized core sample representing the depositional period 1950-74 was also analyzed for four chlorophenoxy-acid herbicides that were widely used during that time period. The surficial core segment, that corresponding to the 1975-95 depositional period, was analyzed for 52 semi-volatile organic compounds, and oil and grease. The analytical methods used for the detailed sediment quality sites are listed in table 6 .

\section{SUMMARY OF RESULTS}

The following is a synopsis of the results obtained as part of the sampling conducted of the water quality and bottom sediments of the estuary system. A site reconnaissance and the first sampling of bottom sediments was carried out from December $12-16,1994$. Water quality sites were sampled from March 15-16, 1995, during dry weather conditions. The water quality sites were sampled again from May 17-18, 1995, following a significant storm-runoff event. Finally, the sediment sites were sampled from July 18-20, 1995, for exploratory sediment analysis and detailed analysis of selected constituents from the depth intervals corresponding to 1925-49, 1950-74, and 1975-95.

All field data and analytical results are given in the appendix of the report as follows:

- Appendix 1-In-situ determination of specific conductance, $\mathrm{pH}$, and dissolved oxygen levels with depth for sediment and water-quality sites sampled in March, May, and July 1995, in the San Juan Bay estuary system, Puerto Rico.

- Appendix 2- Secchi depth, color, turbidity, and total suspended solids in the surface waters for 15 exploratory water quality sites sampled during March 1995 (dry weather period) and May 1995 (wet weather period), in the San Juan Bay estuary system, Puerto Rico.

- Appendix 3-Analytical results for dissolved nutrients, fecal coliform bacteria, and chlorophyll 'a' and ' $b$ ' for 15 exploratory water quality sites sampled during March 1995 (dry period) and May 1995 (wet period), in the San Juan Bay estuary system, Puerto Rico.

- Appendix 4-Particle-size distribution, moisture content, nutrients and total carbon concentrations in surficial bottom sediment samples at nine exploratory designated bottom sediment sampling sites and at the six detailed sediment sampling sites, in the San Juan Bay estuary system, Puerto Rico.

- Appendix 5-Particle-size distribution and cesium-137 analytical results for discrete depth intervals at six bottom sediment core sites, in the San Juan Bay estuary system, Puerto Rico. 
Table 6. Analytes and methods used in sediment core samples

[Intervals approximated using average sedimentation rates: I, 1975-95; II, 1950-74; III, 1925-49. mBq/g, milliBecquerels per gram; $\mathrm{mg} / \mathrm{g}$, micrograms per gram - equivalent to parts per million; $\mathrm{mg} / \mathrm{kg}$, micrograms per kilogram - equivalent to parts per billion;

PCB, polychlorinated biphenyl; PCN, polychlorinated naphthalene; DDD, dichlorodiphenyldichloroethane; DDE,

dichlorodiphenyldichloroethelene; DDT, dichlorodiphenyltrichloroethane; 2,4-D, (2,4-dichlorophenoxy) acetic acid; 2,4-DP,

2-(2,4-dichlorophenoxy) propionic acid; 2,4,5-T, (2,4,5-trichlorophenoxy) acetic acid]

\begin{tabular}{|c|c|c|c|}
\hline Parameter & Units & $\begin{array}{l}\text { Minimum } \\
\text { reporting limit }\end{array}$ & Methodology ${ }^{1}$ \\
\hline Cesium-137 & $\mathrm{mBq} / \mathrm{g}$ & 1 & Gamma counting, McHenry and others (1980) \\
\hline Lead-210 & $\mathrm{mBq} / \mathrm{g}$ & 1 & Gamma counting, Durham and Joshi (1980) \\
\hline Trace Elements & $\mu g / g$ & & Extraction procedure \\
\hline Intervals $I, I I$, and III & $\begin{array}{l}\text { To be reported as } \\
\text { total recoverable }\end{array}$ & & $I-5485-85$ \\
\hline Arsenic & $\mu g / g$ & 1. & $\begin{array}{l}\text { Atomic Absorbtion (AA) } \\
\text { I-6062-85 }\end{array}$ \\
\hline Barium & $\mu g / g$ & 10. & $A A-\mathrm{I}-5084-85$ \\
\hline Cadmium & $\mu g / g$ & 1. & $A A-\mathrm{I}-5135-85$ \\
\hline Chromium & $\mu g / g$ & 1. & $A A-\mathrm{I}-5236-85$ \\
\hline Lead & $\mu g / g$ & 10. & $A A-\mathrm{I}-5399-85$ \\
\hline Mercury & $\mu g / g$ & 0.01 & Cold vapor method - I-5462-85 \\
\hline Selenium & $\mu g / g$ & 1. & $\begin{array}{c}\text { AA-Hydride, automated } \\
\text { I-6667-85 }\end{array}$ \\
\hline $\begin{array}{l}\text { Semi-Volatile Organic Compounds } \\
\text { Interval I }\end{array}$ & $\mu g / k g$ & & $\begin{array}{c}\text { Gas chromatography/mass spectrometric detector } \\
(\text { GC/MS) } \\
\mathrm{O}-5116-83\end{array}$ \\
\hline 1,2,4-Trichlorobenzene & $\mu g / k g$ & 200 & $G C / M S-0-5116-83$ \\
\hline 1,2,5,6-Dibenzanthracene & $\mu g / k g$ & 400 & $G C / M S-\mathrm{O}-5116-83$ \\
\hline 1,2-Dichlorobenzene & $\mu g / \mathrm{kg}$ & 200 & $G C / M S-0-5116-83$ \\
\hline 1,3-Dichlorobenzene & $\mu g / k g$ & 200 & $G C / M S$ - O-5116-83 \\
\hline 1,4-Dichlorobenzene & $\mu g / k g$ & 200 & $G C / M S-\mathrm{O}-5116-83$ \\
\hline 2,4,6-Trichlorophenol & $\mu g / k g$ & 600 & $G C / M S-\mathrm{O}-5116-83$ \\
\hline 2,4-Dichlorophenol & $\mu g / \mathrm{kg}$ & 200 & $G C / M S-\mathrm{O}-5116-83$ \\
\hline 2,4-Dinitrophenol & $\mu g / \mathrm{kg}$ & 200 & $G C / M S-\mathrm{O}-5116-83$ \\
\hline 2,4-Dinitrotoluene & $\mu g / \mathrm{kg}$ & 200 & $G C / M S-\mathrm{O}-5116-83$ \\
\hline 2,4-Dimethylphenol & $\mu g / k g$ & 200 & $G C / M S-\mathrm{O}-5116-83$ \\
\hline 2,6-Dinitrotoluene & $\mu g / \mathrm{kg}$ & 200 & $G C / M S-\mathrm{O}-5116-83$ \\
\hline 2-Chloronaphthalene & $\mu g / k g$ & 200 & $G C / M S-\mathrm{O}-5116-83$ \\
\hline 2-Chlorophenol & $\mu g / \mathrm{kg}$ & 200 & $G C / M S-\mathrm{O}-5116-83$ \\
\hline 2-Nitrophenol & $\mu g / k g$ & 200 & $G C / M S-\mathrm{O}-5116-83$ \\
\hline $\begin{array}{l}\text { 2-Methyl-4,6-dinitrophenol } \\
\text { (4,6-dinitroorthocresol) }\end{array}$ & $\mu g / k g$ & 600 & $G C / M S-\mathrm{O}-5116-83$ \\
\hline 4-Chlorophenylphenylether & $\mu g / k g$ & 200 & $G C / M S-\mathrm{O}-5116-83$ \\
\hline 4-Nitrophenol & $\mu g / \mathrm{kg}$ & 600 & $G C / M S-\mathrm{O}-5116-83$ \\
\hline 4-Bromophenylphenylether & $\mu g / k g$ & 200 & $G C / M S-\mathrm{O}-5116-83$ \\
\hline Acenapthene & $\mu g / k g$ & 200 & $G C / M S-0-5116-83$ \\
\hline Acenaphthylene & $\mu g / k g$ & 200 & $G C / M S-\mathrm{O}-5116-83$ \\
\hline Anthracene & $\mu g / k g$ & 200 & $G C / M S-0-5116-83$ \\
\hline Benzo (a) pyrene & $\mu g / \mathrm{kg}$ & 400 & $G C / M S-\mathrm{O}-5116-83$ \\
\hline Benzo (b) fluoranthene & $\mu g / \mathrm{kg}$ & 400 & $G C / M S-\mathrm{O}-5116-83$ \\
\hline Benzo (k) fluoranthene & $\mu g / \mathrm{kg}$ & 400 & $G C / M S-0-5116-83$ \\
\hline $\begin{array}{l}\text { Benzo(a)anthracene } \\
\text { (1,2-benzanthracene) }\end{array}$ & $\mu g / k g$ & 400 & $G C / M S-\mathrm{O}-5116-83$ \\
\hline $\begin{array}{l}\text { Benzo(g,h,i)perylene } \\
\text { (1,12-benzoperylene) }\end{array}$ & $\mu g / k g$ & 400 & $G C / M S-\mathrm{O}-5116-83$ \\
\hline Bis(2-chloroethoxy) methane & $\mu g / k g$ & 200 & $G C / M S-\mathrm{O}-5116-83$ \\
\hline Bis (2-chloroethyl) ether & $\mu g / k g$ & 200 & $G C / M S-0-5116-83$ \\
\hline Bis(2-choroisopropyl) ether & $\mu \mathrm{g} / \mathrm{kg}$ & 200 & $G C / M S-0-5116-83$ \\
\hline Bis(2-ethylhexyl) phthalate & $\mu g / k g$ & 200 & $G C / M S-0-5116-83$ \\
\hline Butyl benzyl phthalate & $\mu g / \mathrm{kg}$ & 200 & $G C / M S-\mathrm{O}-5116-83$ \\
\hline
\end{tabular}


Table 6. Analytes and methods used in sediment core samples-Continued

\begin{tabular}{|c|c|c|c|}
\hline Parameter & Units & $\begin{array}{l}\text { Minimum } \\
\text { reporting limit }\end{array}$ & Methodology 1 \\
\hline 3-Chloro-3-methylphenol & $\mu g / k g$ & 600 & $G C / M S-0-5116-83$ \\
\hline Chrysene & $\mu g / k g$ & 400 & $G C / M S-0-5116-83$ \\
\hline Di-n-butyl phthalate & $\mu g / k g$ & 200 & $G C / M S-0-5116-83$ \\
\hline Di-n-octyl phthalate & $\mu g / k g$ & 400 & $G C / M S-O-5116-83$ \\
\hline Diethyl phthalate & $\mu g / k g$ & 200 & $G C / M S-0-5116-83$ \\
\hline Dimethyl phthalate & $\mu g / k g$ & 200 & $G C / M S-\mathrm{O}-5116-83$ \\
\hline Fluoranthene & $\mu g / k g$ & 200 & $G C / M S-O-5116-83$ \\
\hline Fluorene & $\mu g / k g$ & 200 & $G C / M S-\mathrm{O}-5116-83$ \\
\hline Hexachlorobenzene & $\mu g / k g$ & 200 & $G C / M S-O-5116-83$ \\
\hline Hexachlorobutadiene & $\mu g / \mathrm{kg}$ & 200 & $G C / M S-O-5116-83$ \\
\hline Hexachlorocyclopentadiene & $\mu g / k g$ & 200 & $G C / M S-0-5116-83$ \\
\hline Hexachloroethane & $\mu g / k g$ & 200 & $G C / M S-\mathrm{O}-5116-83$ \\
\hline Indeno (1,2,3-cd) pyrene & $\mu g / k g$ & 400 & $G C / M S-0-5116-83$ \\
\hline Isophorone & $\mu g / k g$ & 200 & $G C / M S-O-5116-83$ \\
\hline N-Nitrosodi-n-propylamine & $\mu g / k g$ & 200 & $G C / M S-\mathrm{O}-5116-83$ \\
\hline N-Nitrosodimethylamine & $\mu g / \mathrm{kg}$ & 200 & $G C / M S-0-5116-83$ \\
\hline N-Nitrosodiphenylamine & $\mu g / k g$ & 200 & $G C / M S-0-5116-83$ \\
\hline Naphthalene & $\mu g / \mathrm{kg}$ & 200 & $G C / M S-\mathrm{O}-5116-83$ \\
\hline Nitrobenzene & $\mu g / \mathrm{kg}$ & 200 & $G C / M S-0-5116-83$ \\
\hline Pentachlorophenol & $\mu g / \mathrm{kg}$ & 600 & $G C / M S-0-5116-83$ \\
\hline Phenanthrene & $\mu g / k g$ & 200 & $G C / M S-0-5116-83$ \\
\hline Phenol & $\mu g / k g$ & 200 & $G C / M S-\mathrm{O}-5116-83$ \\
\hline Pyrene & $\mu g / \mathrm{kg}$ & 200 & $G C / M S-\mathrm{O}-5116-83$ \\
\hline Oil and Grease & $m g / k g$ & 1000 & $\begin{array}{l}\text { Spectrophotometric, Infrared } \\
\text { modified from EPA Method \#413.2 }\end{array}$ \\
\hline Organochlorine Insecticides & & & Gas chromatography/electron capture detector \\
\hline with gross PCB's and PCN's & & & $(G C / E C D)$ \\
\hline Intervals $I, I I$, and III & & & O-5104-83 \\
\hline Aldrin & $\mu g / k g$ & 0.01 & $G C / E C D-0-5104-83$ \\
\hline Chlordane & $\mu g / k g$ & 0.1 & $G C / E C D$ - O-5104-83 \\
\hline DDD & $\mu g / \mathrm{kg}$ & 0.01 & $G C / E C D-\mathrm{O}-5104-83$ \\
\hline DDE & $\mu g / k g$ & 0.01 & $G C / E C D$ - O-5104-83 \\
\hline DDT & $\mu g / k g$ & 0.01 & $G C / E C D-0-5104-83$ \\
\hline Dieldrin & $\mu g / k g$ & 0.01 & $G C / E C D-O-5104-83$ \\
\hline Endosulfan & $\mu g / k g$ & 0.01 & $G C / E C D-0-5104-83$ \\
\hline Endrin & $\mu g / k g$ & 0.01 & $G C / E C D-\mathrm{O}-5104-83$ \\
\hline Gross PCB's & $\mu g / k g$ & 0.1 & $G C / E C D-0-5104-83$ \\
\hline Gross PCN's & $\mu g / \mathrm{kg}$ & 0.1 & $G C / E C D-\mathrm{O}-5104-83$ \\
\hline Heptachlor & $\mu g / k g$ & 0.01 & $G C / E C D-0-5104-83$ \\
\hline Heptachlor epoxide & $\mu g / \mathrm{kg}$ & 0.01 & $G C / E C D$ - O-5104-83 \\
\hline Lindane & $\mu g / \mathrm{kg}$ & 0.01 & $G C / E C D-\mathrm{O}-5104-83$ \\
\hline Methoxychlor & $\mu g / \mathrm{kg}$ & 0.01 & $G C / E C D-O-5104-83$ \\
\hline Mirex & $\mu g / k g$ & 0.01 & $G C / E C D-O-5104-83$ \\
\hline Perthane & $\mu g / \mathrm{kg}$ & 1 & $G C / E C D-0-5104-83$ \\
\hline Toxaphene & $\mu g / k g$ & 10 & $G C / E C D-0-5104-83$ \\
\hline Chlorophenoxy-acid herbicides & $\mu g / k g$ & & Gas chromatography/electron capture detector \\
\hline \multirow[t]{2}{*}{ Interval II } & & & $(G C / E C D)$ \\
\hline & & & O-5105-83 \\
\hline $2,4,5-\mathrm{T}$ & $\mu g / k g$ & 0.1 & $G C / E C D-O-5105-83$ \\
\hline 2,4-D & $\mu g / \mathrm{kg}$ & 0.1 & $G C / E C D-\mathrm{O}-5105-83$ \\
\hline 2,4-DP & $\mu g / \mathrm{kg}$ & 0.1 & $G C / E C D-\mathrm{O}-5105-83$ \\
\hline Silvex & $\mu g / k g$ & 0.1 & $G C / E C D-0-5105-83$ \\
\hline
\end{tabular}

${ }^{1}$ The initial letter of the method identification code identifies the field of analysis: I (inorganic) or O (organic). The four digits in the middle specify the analytical method, whereas the last two digits identify the year that the method was last revised. These methods are detailed in USGS reports edited by Fishman (1993) (inorganic and organic), Fishman and Friedman (1989) (inorganic), and Wershaw and others (1987) (organics). 
- Appendix 6-Analytical results for organochlorine pesticides and total PCB detected above the minimum reporting level in selected horizons corresponding to depositional periods of 1925-49, 1950-74, and 1975-95 at six core sites samples July 18-19, 1995, in the San Juan Bay estuary system, Puerto Rico.

- Appendix 7-Trace element concentrations in core samples for selected horizons corresponding to depositional periods of $1925-49,1950-74$, and 1975-95 at six core sites samples July 18-19, 1995, in the San Juan Bay estuary system, Puerto Rico.

Because of the limited scope of sampling during this study, associated data sets compiled during past and ongoing studies by the USGS in cooperation with agencies of the Commonwealth of Puerto Rico were accessed and evaluated to identify historical trends in changing water quality in the estuary system.

\section{Associated Data Sets}

Water-quality data for samples collected at sites in the estuary system drainage basin for the years 1970 through present were retrieved from the National Water-Data Storage and Retrieval System (WATSTORE). Direct access to the WATSTORE data base may be obtained by signing a Memorandum of Agreement with the USGS, available through the Survey's National Water Data Exchange office in Reston, Virginia. In addition, data can be provided in various machine-readable formats such as magnetic tape, floppy disk, or compact disk. Yearly WaterResources Data Reports for Puerto Rico and the U.S. Virgin islands are published by the USGS and distributed to libraries, and Federal and Commonwealth agencies. The most recent one presents the data for water year 1996 (Díaz and others, 1996).

The WATSTORE database is populated with data collected by USGS personnel in support of a wide range of missions. Data from 42 sites within the estuarine boundaries (fig. 10) have been collected as part of the USGS-Commonwealth of Puerto Rico water-quality monitoring network or the National Stream Quality Accounting Network (NASQAN), both of which were established to provide data to describe areal variability and detection of changes or trends in water-quality characteristics over broad geographical areas.

\section{Water Quality}

The Bahía de San Juan, Caño de Martín Peña, and Laguna San José are classified by the PREQB (1990) as class SC waters, coastal waters intended for uses where the human body may come into indirect contact with the water (such as fishing and boating), and for use in propagation and preservation of desirable species. The Laguna La Torrecilla and Laguna de Piñones are classified as SB waters, coastal waters and estuarine waters intended for use in primary and secondary contact recreation, and for propagation and preservation of desirable species. The rivers are classified as SD waters, surface waters intended for use as a raw source of public water supply, propagation and preservation of desirable species, and primary and secondary contact recreation. Previous studies have documented the degraded water quality in the San Juan metropolitan area in general (PREQB, 1984; USEPA, 1992). As in the past (USACE, 1978), the Caño de Martín Peña continues to be noted as in need of particular attention.

\section{Field Observations of Temperature, Specific Conductance, $\mathrm{pH}$, and Dissolved Oxygen}

To comply with the Water Quality Standard (PREQB, 1990) for SB and SC waters, activities should not result in an increase of water temperatures above $32.2{ }^{\circ} \mathrm{C}$ and the acidity of the waters will remain within the range 7.3 to $8.5 \mathrm{pH}$ units. The only criteria for dissolved solids for SC waters are that sulfates shall not exceed $2,800 \mathrm{mg} / \mathrm{L}$ and that soaprelated, methylene-blue-active substances (MBAS) shall not exceed $500 \mathrm{mg} / \mathrm{L}$. The latter standard may have a typographical error as it is a limit of $500 \mu \mathrm{g} / \mathrm{L}$ above which foaming of the waters commonly occurs (Barber and others, 1995). SB waters (Laguna La Torrecilla and Laguna de Piñones) have a higher standard for dissolved oxygen, $5 \mathrm{mg} / \mathrm{L}$ than the $\mathrm{SC}$ waters (Bahía de San Juan to Laguna San José) which have a standard of $4 \mathrm{mg} / \mathrm{L}$.

The upland monitoring sites are classified as SD waters with the following standards for $\mathrm{pH}$ and dissolved solids. The acidity of the waters shall remain within the range 6.0 to $9.0 \mathrm{pH}$ units, except in response to natural causes. Total dissolved solids shall not exceed $500 \mathrm{mg} / \mathrm{L}$; and shall contain not less than 4 $\mathrm{mg} / \mathrm{L}$ of dissolved oxygen (DO) except when natural conditions cause this value to be depressed. 


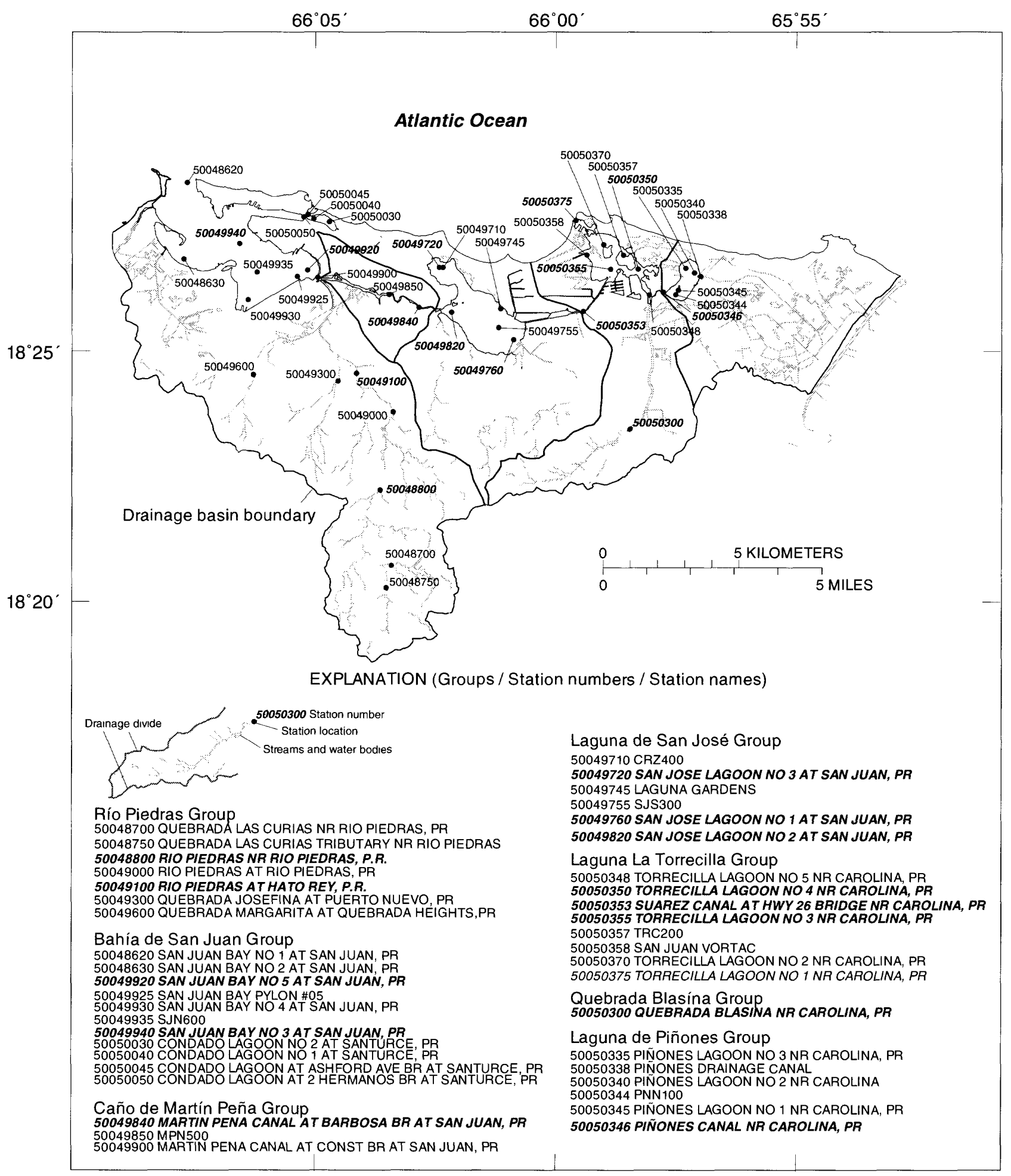

Figure 10. Location of 42 USGS quality-of-water stations in the San Juan Bay estuary drainage basin in northern Puerto Rico. These surface-water sites were sampled either during this study or during past and ongoing quality-of-water studies carried out in cooperation with Federal and Commonwealth agencies. Data from groups of sites and from selected individual sites are presented and discussed in the report. Stations shown on the map and listed in the explanation in bold italics have been sampled at least 50 times during the period 1970 to 1996. 
Temperature-Temperature variation throughout the estuary system was most significant between the two sampling dates than within the estuary system. Lowest temperatures were obtained in March 1995 (about $25^{\circ} \mathrm{C}$ ) and highest in July 1995 (about $30^{\circ} \mathrm{C}$ ). Vertical temperature variation was most significant at the dredged sample site in Laguna San José with a difference of $3{ }^{\circ} \mathrm{C}\left(24.5^{\circ} \mathrm{C}\right.$ surface, 27.5 ${ }^{\circ} \mathrm{C}$ at $4 \mathrm{~m}$; March 1995).

Specific conductance-Specific conductance in the estuary system ranges from about $53,000 \mu \mathrm{S} / \mathrm{cm}$ (zones with 100 percent seawater) to $19,000 \mu \mathrm{S} / \mathrm{cm}$ where freshwater inputs are significant. Zones with the highest proportion of freshwater to seawater are the Caño de Martín Peña (19,000 $\mu \mathrm{S} / \mathrm{cm}$ or a mix of 35 percent seawater); Laguna San José (generally $30,000 \mu \mathrm{S} / \mathrm{cm}$ or about 45 percent seawater at depths less than $2.5 \mathrm{~m}$ ). Laguna La Torrecilla consists principally of seawater with localized freshwater/seawater mixing in the southwestern part (vicinity of Quebrada Blasina): Laguna de Piñones had a maximum specific conductance of 47,000 $\mu \mathrm{S} / \mathrm{cm}$ and a minimum of $18,500 \mu \mathrm{S} / \mathrm{cm}$ (measured at one station during May 1995).

$\mathrm{pH}$ - The lowest measured $\mathrm{pH}$ was at Caño de Martín Peña (6.3 in water with a specific conductance of $19,000 \mu \mathrm{S} / \mathrm{cm}$ ) and the highest $\mathrm{pH}$ was measured in Laguna Los Corozos (8.7, in water with a specific conductance of $19,000 \mu \mathrm{S} / \mathrm{cm}$, and a dissolved oxygen of $13 \mathrm{mg} / \mathrm{L}$ ). Other stations had $\mathrm{pH}$ values of about 7.7. Laguna de Piñones was near 8.0. Eutrophic waters, with their accelerated primary productivity, commonly experience wide daily variations in $\mathrm{pH}$ value.

Dissolved oxygen-Large temporal variations in dissolved oxygen concentrations are typical of eutrophic water bodies. The least variation in dissolved oxygen concentrations observed was in the Bahía de San Juan (generally from 4.5 to $5.5 \mathrm{mg} / \mathrm{L}$ ) which represents oxygen saturation values near 75 percent. Waters with decomposing organic matter and limited circulation often have little to no oxygen. Caño de Martín Peña and the deep waters in the dredged zones in Laguna San José had negligible to zero dissolved oxygen concentrations. In the waters sampled at depths greater than $1 \mathrm{~m}$ in the dredged area in Canal Suárez, concentrations of dissolved oxygen were less than $2.0 \mathrm{mg} / \mathrm{L}$. At the other extreme were concentrations of as much as $14 \mathrm{mg} / \mathrm{L}$ (200 percent of saturation) obtained in shallow waters in Laguna San José near the eastern end of Caño de Martín Peña.
Laguna La Torrecilla had dissolved oxygen concentrations generally at 60 percent of saturation (about $4.5 \mathrm{mg} / \mathrm{L}$ ). At Laguna de Piñones dissolved oxygen ranged from 5.0 to $10 \mathrm{mg} / \mathrm{L}$ (the latter value measured in May 1995).

\section{Secchi Depth, Color, Turbidity, and Suspended Solids in the Surface Waters}

The waters of Puerto Rico shall be free from color, odor, taste, and turbidity attributable to discharges in such a degree as to create a nuisance to the enjoyment of the existing or designated uses of the waterbody (PREQB, 1990). Also solids from wastewater sources shall not cause deposition in or be deleterious to the existing or designated uses of the waters. The turbidity levels for SB and SC waters in the marine portion of the estuary system should be less than 10 nepholometric turbidity units (NTU), whereas the upper limit for SD waters is 50 NTU.

Secchi depth-The secchi depth was greatest at stations Torrecilla \#1 (1.46 m) and San Juan Bay \#1 $(1.52 \mathrm{~m})$, the sites located in the channels connecting the estuary with the ocean. Of the sample sites located within the interior part of the estuary. Laguna San José had the best overall secchi depth (averaging $0.87 \mathrm{~m}$ for dry weather conditions and $0.80 \mathrm{~m}$ for wet weather conditions).

Color-Variations in the water color were observed in the field with a Fore-Ule color comparison kit. The color of the water is an indication of the concentrations of particulate and dissolved organic material. Deep-ocean water is has a Fore-Ule color of I whereas eutrophic lagoons and stagnant waters reach XXIV on the Fore-Ule scale. Colors ranged from V for the Bahía de San Juan to XXI in the Laguna de Piñones. Significant rainfall falling on the mangroves or marshes flushes the humus-rich highly-colored, low suspended-sediment waters from the canals into the lagoons resulting in a decrease in suspended sediment levels with a concurrent increase in turbidity levels.

Turbidity-In general, turbidity in the estuary system is relatively low since there is no significant freshwater streamflow and the salinity is sufficiently high to cause rapid flocculation of suspended sediment and colloidal particles. The highest measured values were 11.0 NTU (station San Juan Bay \#2, dry weather conditions) with values generally less than 6.0 NTU during the dry weather sampling. During wet weather conditions the maximum was 9.1 NTU (station SJ VORTAC) with values generally less than 8.0 NTU. 
Total Suspended Sediment-As with turbidity, suspended sediment concentrations in the estuary system are low. The maximum concentration measured was $31 \mathrm{mg} / \mathrm{L}$ (station San Juan Bay \#2, dry weather) and the minimum $4.6 \mathrm{mg} / \mathrm{L}$ (station San Jose \#3, wet weather) which was comparable to a concentration of $4.5 \mathrm{mg} / \mathrm{L}$ obtained at the drainage channel in the Bosque Estatal de Piñones mangrove forest (during wet weather). In general, suspended sediment concentrations were less than $17 \mathrm{mg} / \mathrm{L}$ during both sampling events.

\section{Dissolved Nutrients, Chlorophyll, and Fecal Coliform Bacteria in the Surface Waters}

Excess nutrients can have a deleterious impact on the estuary system, principally by enhancing primary productivity resulting in decreased water transparency and extreme variations in concentrations in levels of dissolved oxygen. Primary productivity is commonly measured by analyzing the concentrations of pigments (chlorophyll) in the water sampled. Waters enriched by nutrients often receive discharge from agricultural land where fertilizer (nitrogen and phosphorus) has been applied, or where untreated sewage containing bacteria and other pathogens has been discharged. The PREQB has established that total phosphorus in coastal and estuarine waters shall not exceed $1 \mathrm{mg} / \mathrm{L}$ and total nitrogen species shall not exceed $5 \mathrm{mg} / \mathrm{L}$ for coastal and estuarine waters. Total ammonia concentrations (reduced form of nitrogen) in rivers shall not exceed $1 \mathrm{mg} / \mathrm{L}$ except for selected sections of rivers of which the parts of the Río Piedras and Quebrada Blasina are included. For fecal coliform bacteria, the PREQB has established that the geometric mean of 5 samples shall be less than 2,000 colonies per $100 \mathrm{~mL}$ for SC and SD waters and less than 200 colonies per $100 \mathrm{~mL}$ for SB waters.

Nutrients-The nutrients of importance in this analysis are ammonia, nitrate, and orthophosphate. The highest concentrations of ammonia were in the Caño de Martín Peña and at sample sites located near both ends of the channel; at Bahía de San Juan and Laguna San José. Concentrations at the Caño de Martín Peña during both sampling events ranged from 1.6 to $2.3 \mathrm{mg} / \mathrm{L}$ as $\mathrm{N}$. Concentrations were as much as $0.36 \mathrm{mg} / \mathrm{L}$ in Laguna San José near the eastern end of Caño de Martín Peña and $0.15 \mathrm{mg} / \mathrm{L}$ in the Bahía de San Juan near the western end of Caño de Martín Peña. Ammonia nitrogen at Laguna de Piñones ranged from $0.05 \mathrm{mg} / \mathrm{L}$ (dry weather) to $0.09 \mathrm{mg} / \mathrm{L}$ (wet weather). The highest nitrate concentration (oxidized from nitrogen) was in Laguna San José $(0.16 \mathrm{mg} / \mathrm{L}$ as $\mathrm{N}$ ); this value was slightly more than the $0.12 \mathrm{mg} / \mathrm{L}$ obtained at Laguna La Torrecilla during the wet weather sampling. Concentrations of nitrate at the other sample sites were generally less than $0.04 \mathrm{mg} / \mathrm{L}$. Orthophosphate concentrations were greatest in the Caño de Martín Peña, ranging from 0.24 to $0.14 \mathrm{mg} / \mathrm{L}$ as $\mathrm{P}$; concentrations throughout other areas were generally less than $0.04 \mathrm{mg} / \mathrm{L}$.

\section{Chlorophyll' $a$ ' and 'b'-Chlorophyll' $a$ '} concentrations were highest ( 40 to $87 \mu \mathrm{g} / \mathrm{L}$ ) in the Caño de Martín Peña. The next highest concentrations (maximum of $45 \mu \mathrm{g} / \mathrm{L}$ ) was at Laguna de Piñones. The highest concentration at Laguna San José and Laguna La Torrecilla was 20 and $21 \mu \mathrm{g} / \mathrm{L}$, respectively. The lowest concentrations were in the Bahía de San Juan with concentrations in the larger part of the bay averaging about $2.0 \mu \mathrm{g} / \mathrm{L}$. Chlorophyll ' $\mathrm{b}$ ' concentrations were low throughout the estuary system, generally less than $2.0 \mu \mathrm{g} / \mathrm{L}$.

Fecal coliform-Fecal coliform counts range from hundreds of thousands to less than $10 \mathrm{col} / 100$ $\mathrm{mL}$. The greatest fecal coliform counts were obtained at Caño de Martín Peña, ranging from 270,000 to $610,000 \mathrm{col} / 100 \mathrm{~mL}$. Sites adjacent to Caño de Martín Peña, in Bahía de San Juan and Laguna San José, had counts in the low hundreds of thousands. An incidental sample collected from the Caño de Martín Peña where sewage was entering the channel had more than $2,000,000 \mathrm{col} / 100 \mathrm{~mL}$. The lowest counts, $<10$ $\mathrm{col} / 100 \mathrm{~mL}$, were measured at the inlets to Bahía de San Juan and Laguna La Torrecilla where mixing with marine waters is greatest. In general fecal coliform counts increased from dry weather to wet weather samples by a factor of about ten.

\section{Sediment Quality}

No sediment quality criteria have been developed for Puerto Rico although the toxicity of the sediments are commonly analyzed for material dredged from the developed ports around the island (PPB Environmental Laboratories, Inc., 1993). The disposition of dredge materials has long been the main impetus for evaluating quality of sediment dredged from ports in the United States and Puerto Rico (USEPA, 1980; USEPA/USACE, 1994). More 
recently, a variety of approaches has been devised to formulate numerical sediment quality guidelines (SQG's) (Chapman, 1989) to use in linking sediment quality with potential impacts to the local ecosystem and to human health. Approaches include simple comparisons with background concentrations, correlating concentrations of contaminants with observed impacts on the biota, and using detailed models of chemical partitioning and tissue absorbtion rates (MacDonald, 1992). In this report, the concentrations of contaminants in the sediments are compared with background concentrations from upland bed sediments, with the concentrations measured in the oldest strata sampled at the six detailed core sites, and with SQG's developed by MacDonald (1992) for Florida's coastal areas. The subtropical Floridian SQG's were developed for ecosystems similar to those in Puerto Rico, and included modifications of the National Status and Trends Program Approach developed by Long and Morgan (1990). When available, MacDonald also includes new USEPA sediment quality criteria developed using an equilibrium partitioning approach (Di Toro and others, 1991). Using the National Status and Trends Program approach, physical, chemical, and biological data, compiled from many hundreds of contaminated and uncontaminated aquatic sites, are evaluated to determine the concentrations at which a given contaminant has been observed to have an effect on the associated biological community. The probability of an adverse biological effect by the contaminants measured in the San Juan Bay estuary system sediments will be qualified in this report by reference to the No Observed Effects Level (NOEL), and the Probable Effects Level (PEL) reported by MacDonald (1992). Below the NOEL, adverse effects on aquatic organisms were only rarely observed; above the PEL, concentrations of sediment-sorbed contaminants are considered to represent significant and immediate hazards to aquatic organisms (MacDonald, 1992). The range of impacts includes direct toxicity to algae, invertebrates, fish, and other organisms, development of tumors and other abnormalities in bottom feeding fish. It should be noted that the NOEL and PEL do not address the potential for bioaccumulation of persistent toxic chemicals in the tissues of fish and shellfish and the potential adverse effects on higher levels of the food chain (MacDonald, 1992). However, where contaminants with known potential for bioaccumulation are documented above the NOEL, it would be prudent to analyze samples from fish and shellfish intended for human consumption for concentrations of these contaminants in their tissues. The SQG's mentioned in following sections should be used only as a point of reference until SQG's specific to the sediment chemistry and biota of Puerto Rico can be established.

\section{Texture, Macronutrients, and Total Carbon Analyses of Surficial Bottom Sediments}

Although no SQG's have been established for texture, macronutrients, and total carbon, all of these variables affect the potential for toxicity or eutrophication of the overlying water column at a given site. In general, toxins are concentrated in finer sediments with greater concentrations of organic carbon (Horowitz, 1985). The bottom sediments can also be a significant source for diffuse loading of phosphorus during wind and wave induced resuspension of bottom sediments.

Texture-The sediments sampled in the estuary system range from fine clayey silts and clays in Bahía de San Juan and Caño de Martín Peña to organic-rich gravelly silts and sands with abundant shell fragments in Laguna San José, Laguna La Torrecilla, and Laguna de Piñones. The silty clays deposited in Laguna San José were the finest sediments (median diameter of 2.7 $\mu \mathrm{m})$. Most of the surficial sediment deposits throughout were silts and clays. However, in the lagoons, the presence of shell fragments and organic debris in the shallowest sediment layers often altered the verbal classification from silts and clays to silty sands or gravelly sands. Pure, well sorted, quartz sands (greater than 90 percent sand) were sampled at sediment depths greater than $50 \mathrm{~cm}$ at the core site in Laguna Los Corozos, the northern embayment of Laguna San José. Sediments in Caño de Martín Peña and in the dredged areas of Laguna San José contained significant quantities of leaves and organic debris.

Macronutrients and total carbon-

Macronutrient concentrations varied more among sites than in different strata sampled at the same site.

Exploratory and detailed core samples measured in the surface sediment samples and in the core samples included total phosphorus, total kjeldahl nitrogen (TKN) (ammonia + organic nitrogen), and total carbon (inorganic + organic). 
Total phosphorus was highest in the sediments of the Caño de Martín Peña (500 to $880 \mathrm{mg} / \mathrm{kg}$ as P) compared with a range of 100 to $300 \mathrm{mg} / \mathrm{kg}$ for most of the other core sites. Total phosphorus in the surficial bottom sediments had a minimum concentration in Laguna de Piñones (fig. 11) which is comparable to the concentrations in surficial bottom sediments in reservoirs in Puerto Rico (specifically Lagos Dos Bocas, Guajataca, Lago Guayo, and Lago Lucchetti) with significant parts of the their drainage areas dedicated to agriculture purposes but above the minimum of about $300 \mathrm{mg} / \mathrm{kg}$ at Lagos Caríte and Patillas (1978 data in USGS WATSTORE data base).

Accumulation of total phosphorus in bottom sediments of the estuary system is most likely in a declining trend throughout all areas except the Bahía de San Juan and Caño de Martín Peña, as can be inferred from quality of water data obtained at the USGS-Commonwealth of PR cooperative program monitoring network (fig. 12).

The high concentrations of TKN documented in the core samples from Laguna La Torrecilla (up to $4,700 \mathrm{mg} / \mathrm{kg}$ as $\mathrm{N}$ ) seem to correlate with increased concentrations of total carbon at the same site (up to $200 \mathrm{gm} / \mathrm{kg}$ as C). TKN at other sites averaged 2,000 to $3,000 \mathrm{gm} / \mathrm{kg}$ and total carbon ranged from 20 to 40 $\mathrm{gm} / \mathrm{kg}$ in the Bahía de San Juan to $200 \mathrm{gm} / \mathrm{kg}$ in Laguna La Torrecilla.

Whereas this study reports total carbon (inorganic + organic) concentrations in the sediment, the concentration of the total organic carbon alone is needed to calculate the potential toxicity of sediments contaminated with organic compounds as SQG's for many organic compounds are normalized to percent organic carbon. Total carbon concentrations (dry weight) measured in this study ranged from less than 5 percent for the sediments sampled in Bahía de San Juan to 18 percent in the surface sediments in the Piñones drainage canal (50050338). In a previous study (PPB Environmental Laboratories, Inc., 1995), total organic carbon values measured in 11 sediment samples collected from the dredged channels of the Bahía de San Juan ranged from 2 to 5 percent.

\section{Texture and Cesium-137 Analytical Results for Discrete Depth Intervals of Core Samples}

Cores were obtained for grain-size analyses and Cs-137 activity measurements at the following stations: SJN600, MPN500, CRZ400, SJS300, TRC200, and PNN100. By interpreting the variations in Cs-137 activity with depth in the sediment cores, the average sedimentation rates were estimated.

Texture-At all sample sites, except SJN600, distinct strata, or depositional units, could be observed. At SJN600, the entire 0.60 -m core consisted of grey-green clayey silt, very similar texture to the strata from 0.40 to $1.30 \mathrm{~m}$ core depth for the core recovered from the site MPN500, and to the strata from 0.15 to $0.85 \mathrm{~m}$ of the total core depth of $1.02 \mathrm{~m}$ for the Laguna La Torrecilla core. Appreciable quantities of sand- and gravel-size particles were found at core sites CRZ400 (0.25 m to bottom of core at $0.78 \mathrm{~m}$ ); in the upper $0.10 \mathrm{~m}$ at site TRC200; and the upper $0.35 \mathrm{~m}$ at site PNN100. At core site SJS300, gravel-size particles were found only in the upper 0.05 $\mathrm{m}$ and between 0.75 and $0.80 \mathrm{~m}$; most of the core sample contained strata of clayey silt, silty clay, and silt.

Cesium-137-Cs-137 concentrates in depositional areas receiving significant loads of terrestrial sediments. Typical peak values for sediments deposited during the 1960's in deep areas of Lago Loíza sediments ranged from 25 to $30 \mathrm{mBq} / \mathrm{g}$ (Sherwood McIntyre, Department of Agriculture, oral commun., 1992). Peak values for discrete intervals sampled from the sediment cores recovered in the San Juan Bay estuary system were typically much lower, reflecting the smaller drainage areas and greater dilution of terrigenous grains with carbonate skeletal debris and humus common in the estuarine sediments. Site SJN600 is located in the center of the expansive southern part of the Bahía de San Juan, almost $2 \mathrm{~km}$ to the west of the discharge of the Río Puerto Nuevo by way of Caño de Martín Peña. The peak activity of Cs-137 measured in the strata sampled at site SJN600 was $3.6 \mathrm{mBq} / \mathrm{g}$, in the top $5 \mathrm{~cm}$ of the sediment core; Cs-137 activity was not detected above the analytical reporting limit of $1 \mathrm{mBq} / \mathrm{g}$ at depths below $15 \mathrm{~cm}$. The Caño de Martín Peña site, MPN500, receives significant loads of sediment from the Río Puerto Nuevo in addition to numerous combined sewer outfalls located along its southern and northern banks. The peak Cs-137 activity measured in the strata sampled at the Caño de Martín Peña site was 31.2 $\mathrm{mBq} / \mathrm{g}$, in the sediments sampled from 110 to $120 \mathrm{~cm}$ deep, exceeding the activities measured in Lago Loíza. Maximum Cs-137 activity in the sediments cored from 


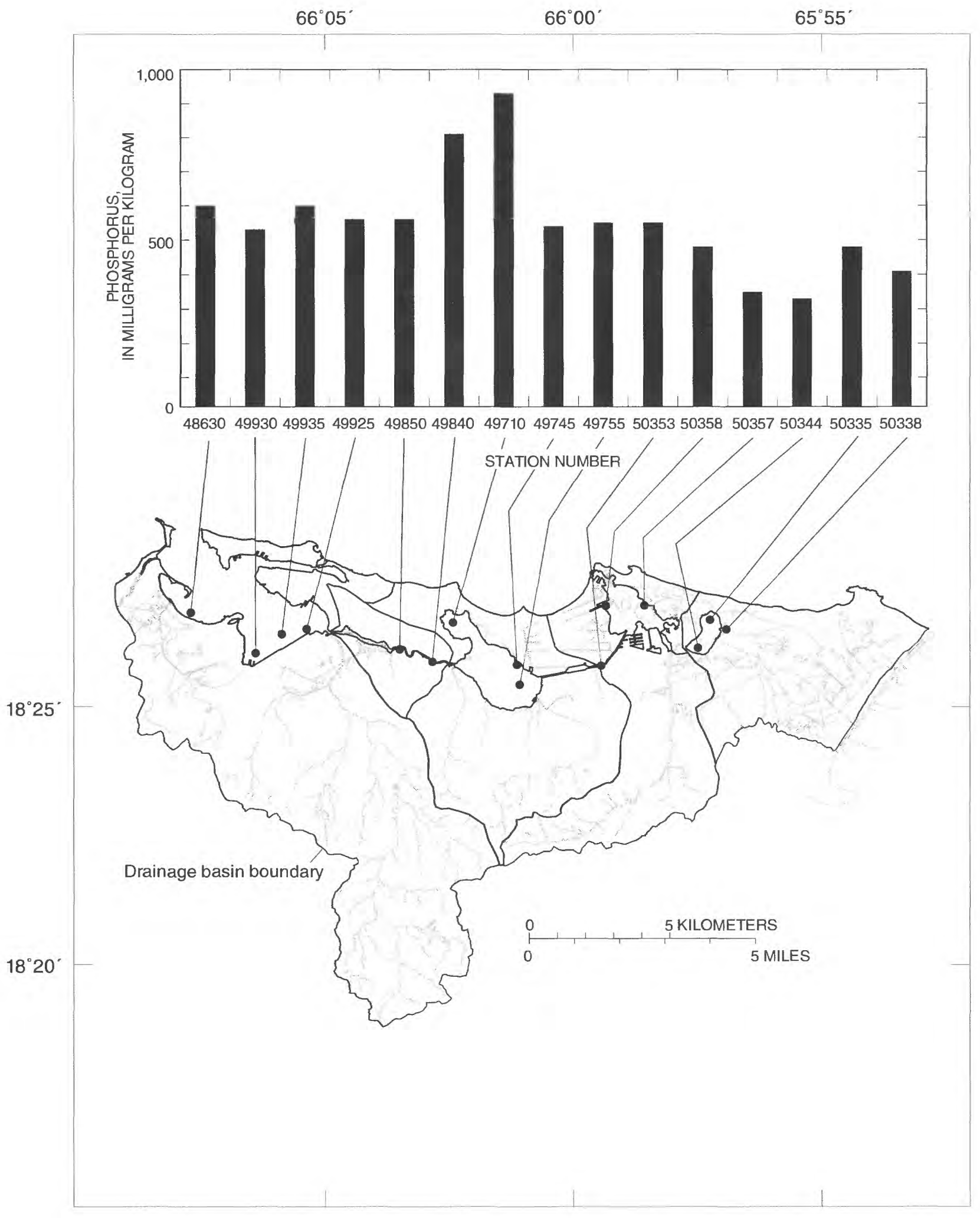

Figure 11. Total phosphorus concentrations in surficial bottom sediment samples, San Juan Bay estuary system, Puerto Rico. 


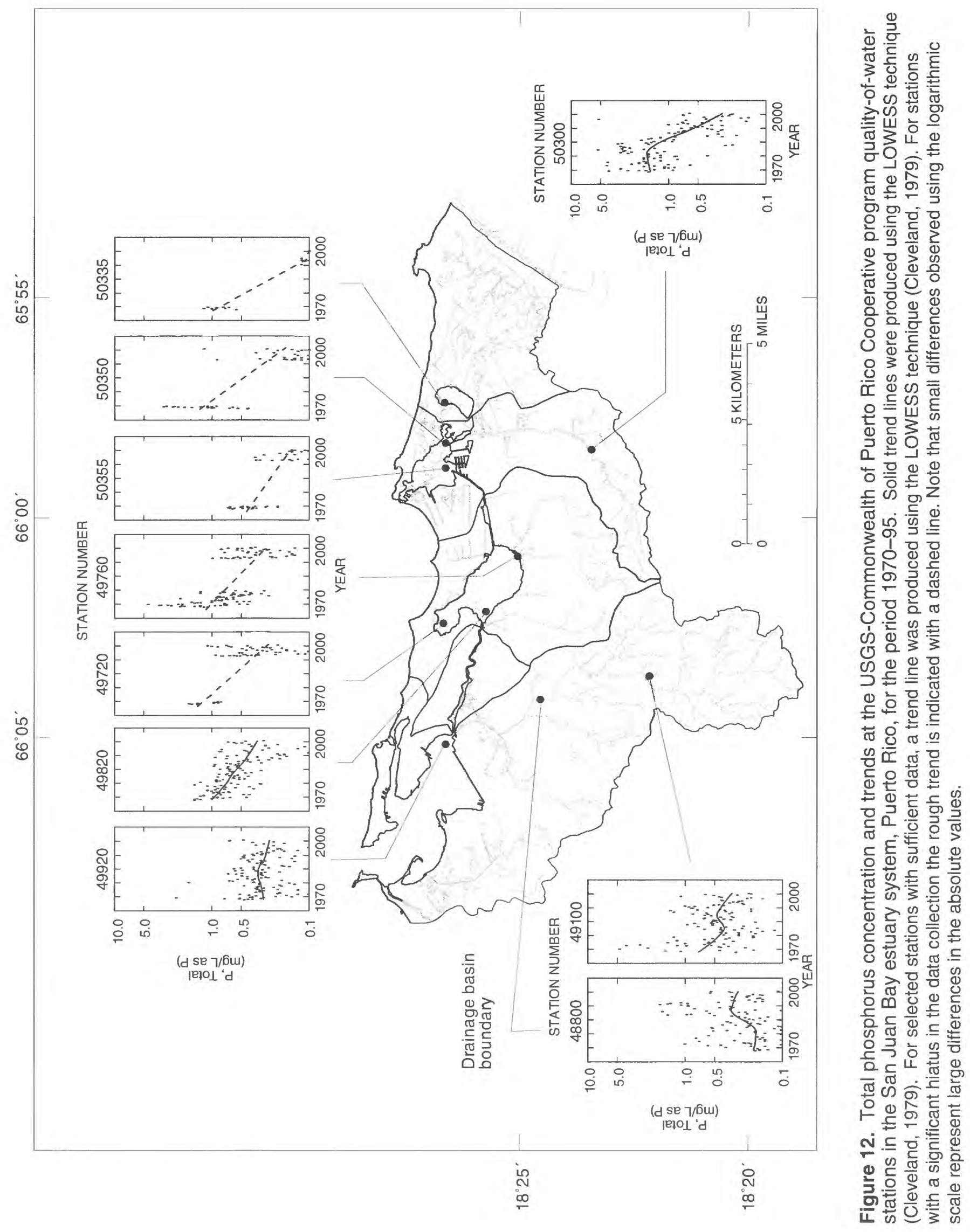


Laguna Los Corozos (site CRZ400) was $11.9 \mathrm{mBq} / \mathrm{g}$, in the strata between 5 and $10 \mathrm{~cm}$ deep. In southern Laguna San José (site SJS300) the maximum Cs-137 activity was $12.9 \mathrm{mBq} / \mathrm{g}$, in the strata between 10 and $15 \mathrm{~cm}$ deep. Circulation is restricted in Laguna San José (and its northern embayment, Laguna Los Corozos) and whatever loads do enter the lagoon from sources around its perimeter are likely to be deposited there. This explains why the sedimentation rates were calculated to be higher at the two remotely located sites in Laguna San José than they were for the site in the Bahía de San Juan. The remaining two core sites in Laguna La Torrecilla (TRC200) and Laguna de Piñones (PNN100) receive only minimal amounts of fine-grained terrigenous sediments, probably deposited in the wake of a major flood. Maximum Cs-137 activity for these sites $(4.5 \mathrm{mBq} / \mathrm{g}$ for TRC200 and $1.5 \mathrm{mBq} / \mathrm{g}$ for PNN100) were measured in the top $5 \mathrm{~cm}$ of the sediment cores.

For all sites, except for the one in Caño de Martín Peña (MPN500), the average vertical accretion rates were estimated by assigning the year 1954 to the base of the lowest strata that had values of Cs-137 greater than the minimum reporting limit of $1 \mathrm{mBq} / \mathrm{g}$. This assumes that approximately 2 years passed after the initial widespread testing of thermonuclear weapons in 1952 (Crusius and Anderson, 1995) before significant quantities of Cs-137 began accumulating in the estuarine sediments. The Caño de Martín Peña site displayed significant activity of Cs-137 even in the deepest samples recovered during the December sampling. For this site, the base of the layer with the highest activity was assigned the year 1965, two years after 1963 (the year of maximum fallout). Using the average sedimentation rates as a guide, the horizons representing the interval from 1925 to 1949 , from 1950 to 1974 , and 1975 to present were defined (table 7). Sedimentation rates were similar throughout the estuary system with the exception of Caño de Martín Peña. Sediments are depositing at the other five sites at rates ranging from $0.24 \mathrm{~cm} / \mathrm{yr}$ in the sheltered Laguna de Piñones to $0.61 \mathrm{~cm} / \mathrm{yr}$ at the Bahía de San Juan and the Laguna La Torrecilla sites. In contrast, storm runoff deposits large amounts of sediment into Caño de Martín Peña resulting in a sedimentation rate of almost $4 \mathrm{~cm} / \mathrm{yr}$ at the shallow coring site MPN500. Sedimentation rates exceeding $10 \mathrm{~cm} / \mathrm{yr}$ are probable where terrestrial runoff enters the low-energy waters over deep dredged areas in Bahía de San Juan, Caño de Martín Peña, Laguna San José, and Laguna La Torrecilla.

Table 7. Average vertical accretion rates, and depth intervals representing the periods $1975-95,1950-74$, and 1925-49 for the six detailed sediment-sampling sites

[Site locations are given in table 2 and shown on figures 7, 8, and 9. Abbreviations: $\mathrm{m}$, meters; cm, centimeters; mBq/g, milliBecquerels per gram; cm/yr, centimeters per year]

\begin{tabular}{|c|c|c|c|c|c|c|c|c|c|}
\hline \multirow{3}{*}{$\begin{array}{c}\begin{array}{c}\text { USGS } \\
\text { station } \\
\text { name }\end{array} \\
\text { SJN600 }\end{array}$} & \multirow{3}{*}{$\begin{array}{c}\begin{array}{c}\text { Water } \\
\text { depth }(\mathrm{m})\end{array} \\
3.7\end{array}$} & \multirow{3}{*}{$\begin{array}{l}\text { Max. depth of Cs-137 } \\
\text { activity }>1 \mathrm{mBq} / \mathrm{g} \text {. } \\
\text { Deeper strata are older } \\
\text { than } 1954(\mathrm{~cm})\end{array}$} & \multirow{3}{*}{$\begin{array}{c}\begin{array}{c}\text { Average } \\
\text { vertical } \\
\text { accretion } \\
\text { rate }(\mathrm{cm} / \mathrm{yr})\end{array} \\
0.61\end{array}$} & \multicolumn{6}{|c|}{$\begin{array}{l}\text { Sampling interval for the time period, in } \\
\text { centimeters below the sediment-water interface - } \\
\text { Sampled in July } 1995(\mathrm{~cm})\end{array}$} \\
\hline & & & & \multicolumn{2}{|c|}{$1995-75$} & \multicolumn{2}{|c|}{$1974-50$} & \multicolumn{2}{|c|}{$1949-25$} \\
\hline & & & & 0 & -12.2 & 12.2 & - $\quad 27.5$ & 27.5 & 42.7 \\
\hline MPN500 & 0.7 & $>130^{1}$ & 3.9 & 0 & -78 & 78 & -178 & 178 & $-273^{2}$ \\
\hline CRZ400 & 2 & 20 & 0.49 & 0 & - $\quad 9.8$ & 9.8 & -22.0 & 22.0 & 34.3 \\
\hline SIS300 & 1.9 & 25 & 0.61 & 0 & -12.2 & 12.2 & - 27.5 & 27.5 & 42.7 \\
\hline TRC200 & 0.9 & 15 & 0.37 & 0 & - $\quad 7.4$ & 7.4 & - 16.6 & 16.6 & $\begin{array}{l}-\quad 25.9\end{array}$ \\
\hline PNN100 & 0.9 & 10 & 0.24 & 0 & $-\quad 4.8$ & 4.8 & $\begin{array}{l}-\quad 10.8 \\
\end{array}$ & 10.8 & 16.8 \\
\hline
\end{tabular}

1 The longest core possible after three attempts on December 16,1994, was $130 \mathrm{~cm}$ at site MPN500 and all core samples had gamma readings greater than $1 \mathrm{mBq} / \mathrm{g}$. See text for details on how the average vertical accretion rate was estimated.

2 The total length of the core sediments obtained at MPN500 during resampling on July 19,1995 was $185 \mathrm{~cm}$. Therefore the oldest sampled strata (178 to $185 \mathrm{~cm}$ ) would represent $1949-48$, not $1949-25$ as was the case for all other cores. 
Organic Compounds and Trace Element Concentrations for Homogenized Core Samples Representing Deposition Periods of 1925-49, 1950-74, and 1975-95

Many organic contaminants bind tightly to the organic carbon present in sediments. Contaminants of this class have their SQG's stated as a concentration of contaminant per concentration of total organic carbon (TOC). An average TOC concentration of 1 percent was used to convert selected SQG's proposed by MacDonald (1992), the USEPA (1993a), or Jaagumagi (1993) to bulk dry weight concentrations (table 8).

Organics-Organic compounds released into the estuary system include carcinogenic, teratogenic, and mutagenic compounds. Many of the compounds have high affinities to lipids in organisms resulting in bioaccumulation and biomagnification in the food chain. Organic compounds of significance that were documented in the estuary system were PCB's, the organochlorinated pesticides (chlordane, dieldrin, DDT plus metabolites), and semi-volatile compounds. PCB's are ubiquitous throughout the system and were measured at concentrations near $20 \mu \mathrm{g} / \mathrm{kg}$ even in Laguna de Piñones. The concentrations of PCB's generally increased from the oldest strata (core segment representative of the 1925-49 depositional period) to the most recent strata (representative of 1975-95) (fig. 13). The most recent sediments deposited at the Caño de Martín Peña site contained $450 \mu \mathrm{g} / \mathrm{kg}$ of PCB's. The Los Corozos site was second to that of Caño de Martín Peña with elevated PCB's $(360 \mu \mathrm{g} / \mathrm{kg})$ in the most recent strata (1975-95), and had the highest concentration of DDE in the strata of sediments deposited during the approximate period 1950-74. Chlordane was detected at a concentration of about $30 \mu \mathrm{g} / \mathrm{kg}$ at the Caño de Martín Peña site (in the 1975-95 segment) and at $7 \mu \mathrm{g} / \mathrm{kg}$ at the Los Corozos site (in the 1975-95 segment). A common plasticizing agent, bis(2 ethylhexyl) phthalate, was the most common semi-volatile organic compound measured with concentrations exceeding $10,000 \mu \mathrm{g} / \mathrm{kg}$ in the most recent sediments deposited at the Caño de Martín Peña site. No oil and grease were measured above the minimum reporting limit of $1,000 \mathrm{mg} / \mathrm{kg}$ in the most recent strata (1975-95) of any core. Neither was any of the 4 chlorophenoxy-acid herbicides detected above the minimum reporting limit of 0.1 $\mu \mathrm{g} / \mathrm{kg}$ in the $1950-74$ strata.

Trace elements - Trace elements are those elements that are normally measured in very low concentrations but whose presence may be essential for physiological activity. A proper diet for humans includes the intake of various trace elements such as potassium, sodium, magnesium, and iron. Studies have also shown that even some heavy metals including molybdenum, manganese, cobalt, copper, and zinc have been also been linked to the human growth process (Garbarino and others, 1995).

Problems occur when biota and humans are exposed to elevated concentrations of elements normally found in trace amounts, above which damage to organs and the nervous system can occur. The potential toxicity of trace elements in the waters and sediments depends heavily on their availability for uptake and incorporation into the food chain. Methylization of certain trace elements, such as arsenic and mercury increases their availability and toxicity (Baudo and others, 1990).

Of the seven trace elements ( $\mathrm{As}, \mathrm{Ba}, \mathrm{Cd}, \mathrm{Cr}, \mathrm{Pb}$, $\mathrm{Hg}$, and $\mathrm{Se}$ ) measured at discrete depth intervals in bottom sediments, only lead and mercury showed significant enrichments in recent sediments above the background concentrations measured for the period 1925-49 (fig. 14). Arsenic concentrations generally declined at all core sites from a maximum in sediments corresponding to the 1925-49 depositional period. Concentrations of As for the base period were $18 \mu \mathrm{g} / \mathrm{g}$ at the Bahía de San Juan site; $16 \mu \mathrm{g} / \mathrm{g}$ at the Laguna San José and Laguna La Torrecilla sites; and about $10 \mu \mathrm{g} / \mathrm{g}$ elsewhere. Barium also averaged about $20 \mu \mathrm{g} / \mathrm{g}$ for all sites except for enrichments of up to 50 $\mu \mathrm{g} / \mathrm{g}$ at the Caño de Martín Peña and Laguna de Corozos sites. Core samples from these sites were the only ones to contain cadmium above the minimum reporting limit of $1 \mu \mathrm{g} / \mathrm{g}$ (maximum of $3 \mu \mathrm{g} / \mathrm{g}$ ). Chromium concentrations ranged from a minimum of $30 \mu \mathrm{g} / \mathrm{g}$ at the Laguna de Piñones core site to almost $50 \mu \mathrm{g} / \mathrm{g}$ at the Caño de Martín Peña and Los Corozos core sites. The background level within the estuary system is approximately $20 \mu \mathrm{g} / \mathrm{g}$ for lead, and in the range of 0.01 to $0.05 \mu \mathrm{g} / \mathrm{g}$ for mercury. Lead concentrations increased to $750 \mu \mathrm{g} / \mathrm{g}$ in the youngest strata at the Caño de Martín Peña site; mercury concentrations rose to $4.7 \mu \mathrm{g} / \mathrm{g}$. Selenium was not detected above the reporting level of $1 \mu \mathrm{g} / \mathrm{g}$ at any site for any strata. The major source for arsenic in the bottom sediments of the estuary system is most likely weathering of arsenic-enriched rocks in the uplands. Bed-material samples from small undisturbed basins in the uplands had arsenic concentrations of almost 20 $\mu \mathrm{g} / \mathrm{g}$ (Marsh, 1992a; Marsh, 1992b). 
Table 8. Sediment quality guidelines for organic compounds and trace elements detected above minimum reporting limits in the core samples collected from the San Juan Bay estuary system, Puerto Rico

[NOEL, No Observed Effect Level; PEL, Probable Effects Level; LEL, Lowest Effect Level; SEL, Severe Effect Level; USEPA, U.S. Environmental Protection Agency; SQC, Sediment Quality Criteria; PCB. Polychlorinated biphenyl; DDD,

dichlorodiphenyldichloroethane; DDE, dichlorodiphenyldichloroethelene; DDT, dichlorodiphenyltrichloroethane; $\mu \mathrm{g} / \mathrm{g}$, micrograms per gram of dry sediment (parts per million); $\mu \mathrm{g} / \mathrm{kg}$, micrograms per kilogram of dry sediment (parts per billion); $\mu \mathrm{g} / \mathrm{g}_{\mathrm{oc}}$, micrograms per gram of organic carbon; NA, - , data not available or not determined]

\begin{tabular}{|c|c|c|c|}
\hline & \multicolumn{3}{|c|}{$\begin{array}{l}\text { Sediment-quality guidelines suggested for Florida } \\
\text { (MacDonald, 1992), unless otherwise footnoted }\end{array}$} \\
\hline & Units & NOEL & PEL \\
\hline \multicolumn{4}{|c|}{ ORGANOCHLORINE COMPOUNDS } \\
\hline Total PCB's & $\mu \mathrm{g} / \mathrm{kg}$ & 25 & 270 \\
\hline \multicolumn{4}{|l|}{ Pesticides } \\
\hline \multicolumn{4}{|l|}{ Organochlorine insecticides } \\
\hline chlordane & $\mu \mathrm{g} / \mathrm{kg}$ & $\mathrm{LEL}^{1}-7$ & $\mathrm{SEL}^{1}-60$ \\
\hline $\mathrm{p}, \mathrm{p}^{\prime}-\mathrm{DDD}$ & $\mu \mathrm{g} / \mathrm{kg}$ & - & - \\
\hline$p, p^{\prime}-D D E$ & $\mu \mathrm{g} / \mathrm{kg}$ & 1.7 & 100 \\
\hline $\mathrm{p}, \mathrm{p}^{\prime}-\mathrm{DDT}$ & $\mu \mathrm{g} / \mathrm{kg}$ & - & - \\
\hline Total DDT and metabolites & $\mu \mathrm{g} / \mathrm{kg}$ & 2.3 & 300 \\
\hline dieldrin & $\mu \mathrm{g} / \mathrm{kg}$ & - & $200\left(\right.$ EPA SQC $\left.^{2}\right)$ \\
\hline \multicolumn{4}{|l|}{ SEMI-VOLATILE COMPOUND } \\
\hline \multicolumn{4}{|c|}{ Polycyclic Aromatic Hydrocarbons (PAH's) } \\
\hline \multicolumn{4}{|c|}{ Low molecular weight (LMW) PAH's } \\
\hline benzo(b)fluoranthene & $\mu \mathrm{g} / \mathrm{kg}$ & LEL $^{3} 240$ & SEL $^{3} 13400$ \\
\hline Sum LMW-PAHs & $\mu \mathrm{g} / \mathrm{kg}$ & 250 & 2,500 \\
\hline \multicolumn{4}{|c|}{ High molecular weight (HMW) PAH's } \\
\hline benzo(a)anthracene & $\mu \mathrm{g} / \mathrm{kg}$ & 160 & 1,500 \\
\hline fluoranthene & $\mu \mathrm{g} / \mathrm{kg}$ & 380 & $\begin{array}{l}3,900,(\text { USEPA } \\
\left.\text { SQC }^{4}-3,000\right)\end{array}$ \\
\hline pyrene & $\mu \mathrm{g} / \mathrm{kg}$ & 300 & 1,900 \\
\hline Sum HMW-PAH's & $\mu \mathrm{g} / \mathrm{kg}$ & 900 & 9,000 \\
\hline Total PAH's & $\mu \mathrm{g} / \mathrm{kg}$ & 2.900 & 29.000 \\
\hline \multicolumn{4}{|l|}{ Phthalates } \\
\hline Bis(2-ethylhexl) phthalate & $\mu \mathrm{g} / \mathrm{kg}$ & - & - \\
\hline Butylbenzylphtalate & $\mu \mathrm{g} / \mathrm{kg}$ & - & - \\
\hline \multicolumn{4}{|l|}{ TRACE ELEMENTS } \\
\hline Arsenic (As) & $\mu \mathrm{g} / \mathrm{g}$ & 10 & 70 \\
\hline Barium $(\mathrm{Ba})$ & $\mu \mathrm{g} / \mathrm{g}$ & - & - \\
\hline Cadmium (Cd) & $\mu \mathrm{g} / \mathrm{g}$ & 1 & 8.6 \\
\hline Chromium $(\mathrm{Cr})$ & $\mu \mathrm{g} / \mathrm{g}$ & 35 & 230 \\
\hline Lead $(\mathrm{Pb})$ & $\mu \mathrm{g} / \mathrm{g}$ & 25 & 170 \\
\hline Mercury $(\mathrm{Hg})$ & $\mu \mathrm{g} / \mathrm{g}$ & 0.15 & 1.4 \\
\hline Selenium (Se) & $\mu \mathrm{g} / \mathrm{g}$ & - & - \\
\hline \multicolumn{4}{|c|}{$\begin{array}{l}{ }^{2} \text { USEPA sediment quality criteria for dieldrin for protection of saltwater benthic organisms (USEPA, 1993a) is } 20 \mu \mathrm{g} / \mathrm{g}_{\mathrm{oc}} \text { which } \\
\text { equivalent to } 200 \mu \mathrm{g} / \mathrm{kg} \text { bulk dry weight concentration assuming a total organic carbon concentration of } 1 \text { percent. }\end{array}$} \\
\hline \multicolumn{4}{|c|}{${ }^{3}$ Converted to bulk dry weight concentration assuming a total organic carbon concentration of 1 percent (Jaagumagi, 1994$)$} \\
\hline \multicolumn{4}{|c|}{$\begin{array}{l}{ }^{4} \text { USEPA sediment quality criteria for fluoranthene for protection of saltwater benthic organisms (USEPA, } 1993 \mathrm{~b} \text { ) is } 300 \mu \mathrm{g} / \mathrm{g} \text { oc } \\
\text { which is equivalent to } 3,000 \mu \mathrm{g} / \mathrm{kg} \text { bulk dry weight concentration assuming a total organic carbon concentration of } 1 \text { percent. }\end{array}$} \\
\hline
\end{tabular}




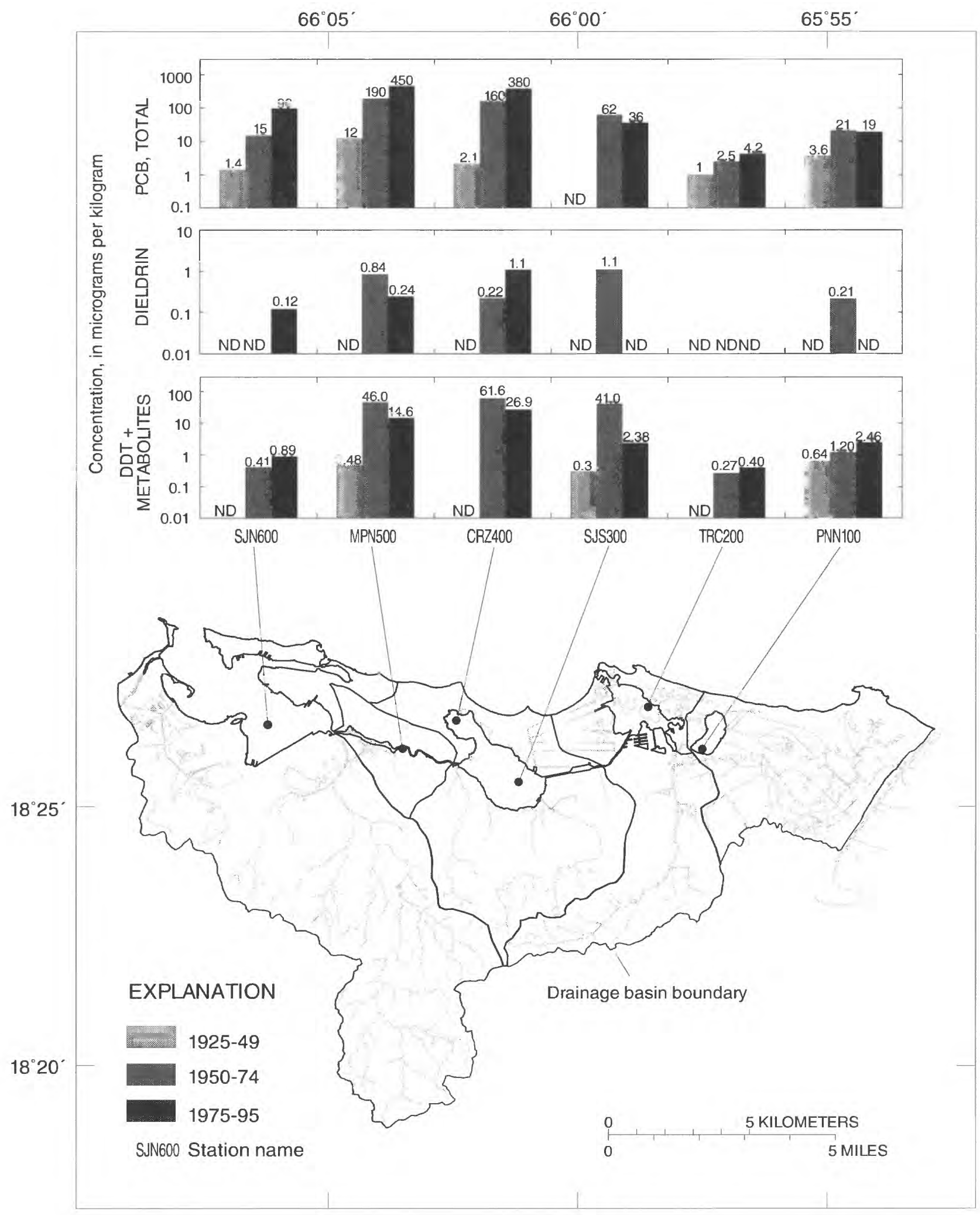

Figure 13. PCB's, Dieldrin, and DDT plus metabolites concentrations in the bottom sediments at six core sites in the San Juan Bay estuary system, Puerto Rico, for the estimated periods 1925-49, 1950-74, and 1975-95. Note that small differences observed using the logarithmic scale represent large differences in the absolute values. 


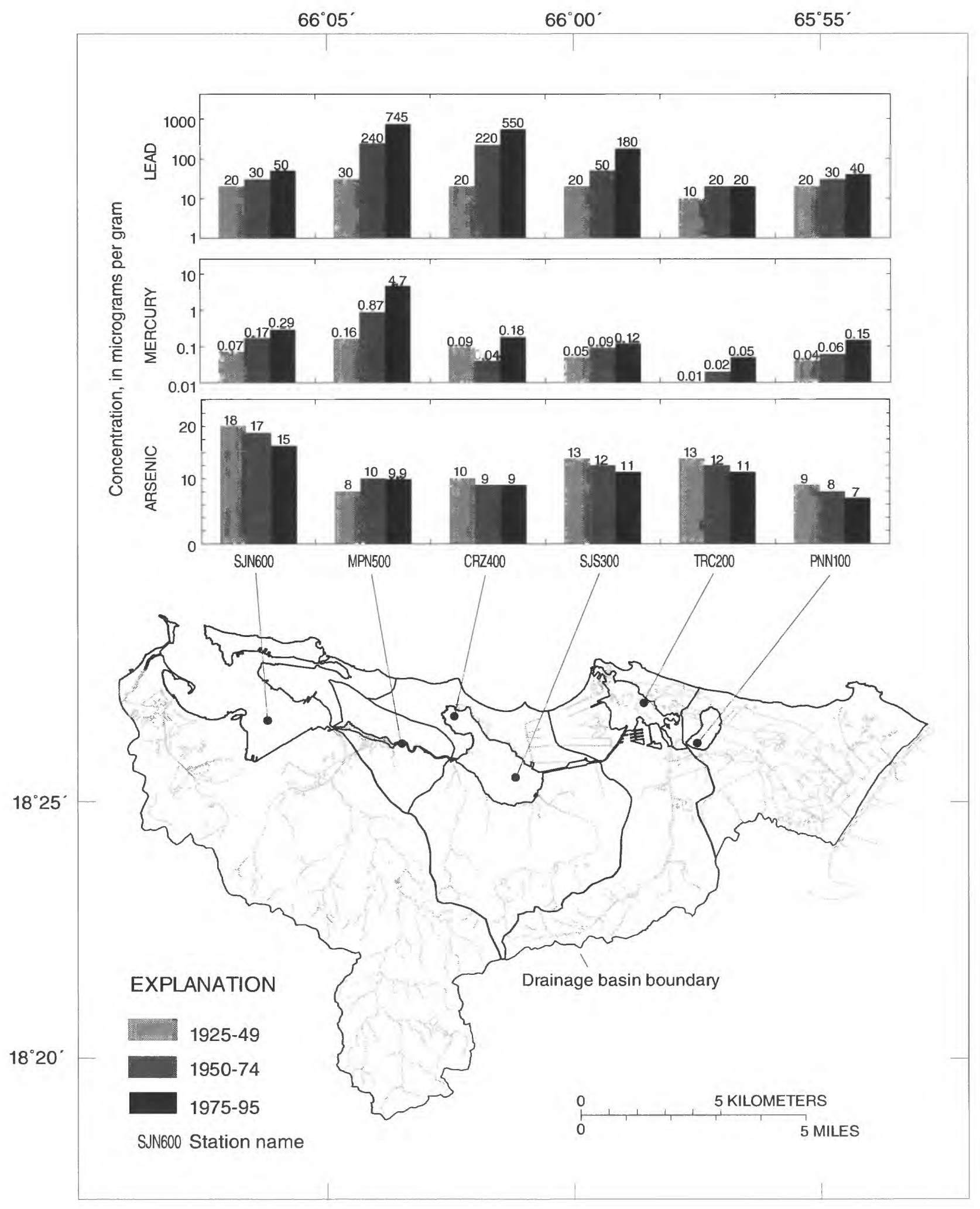

Figure 14. Lead, mercury, and arsenic concentrations in the bottom sediments at six core sites in the San Juan Bay estuary system, Puerto Rico, for the estimated time periods 1925-49, 1950-74, and 1975-95. Note that small differences observed using the logarithmic scale used for lead and mercury represent large differences in the absolutes values. 
As with the organochlorine compounds, both lead and mercury concentrations are expected to decline in surficial bottom sediments as a result of discontinued use of leaded gasoline in 1985 (the major source of lead in urban runoff prior to its ban) and the banned use of mercury in manufactured products. Their decline in the concentration of bottom sediments is not yet evident in the chronostatigraphic core samples because of the large time intervals ( 25 years) composited for the sample analysis. However, the concentrations of total recoverable lead measured in quality of water samples from the Río Piedras and Quebrada Blasina (part of the USGS-Commonwealth of PR cooperative program monitoring network) have declined from generally more than $10 \mu \mathrm{g} / \mathrm{L}$ before 1985 to less than $5 \mu \mathrm{g} / \mathrm{L}$ for recent samples (fig. 15). Since lead is essentially transported in the suspended sediment load of streams (as is typical for most water insoluble contaminants), this indicates that the flux of contaminants from the watershed to the estuary system is relatively rapid (years instead of decades).

\section{ENVIRONMENTAL QUALITY OF THE ESTUARY SYSTEM AND TRENDS}

The results of the synoptic water and bottomsediment survey can be used to put in perspective the impact of urban development in the watershed and degradation of the environmental water quality of the estuary system.

\section{Water Quality}

Pollution control measures have improved overall water quality in the Bahía de San Juan, Quebrada Blasina, Laguna La Torrecilla, and Laguna de Piñones. However, degraded water quality in the Río Piedras, corresponding to intensive urbanization in the Río Piedras uplands, has also been measured.

\section{Dissolved Oxygen, pH, and Chlorophyll'a'}

Dissolved oxygen, $\mathrm{pH}$, and chlorophyll 'a' are quality-of-water parameters which can be used to define trends and infer if the quality of water in the estuary system is degrading or improving. The absolute concentration of dissolved oxygen in the estuary system is controlled primarily by physical variables (temperature, pressure, and salinity) and by the level of primary productivity. In the absence of biotic activity, the maximum concentration of dissolved oxygen is limited to the saturation value at the given temperature, pressure and salinity. Natural systems contain a mixture of photosynthetic algae, bacteria, organic material, and nutrients. Dissolved oxygen concentrations fluctuate daily, increasing steadily throughout the day as the photosynthetic algae proliferate and reaching maximum concentrations in the late afternoon. With the onset of dusk, photosynthesis slows and oxygen demand increases. Throughout the night, respiring bacteria consume oxygen as they break down the dead algal cells and other organic material present in the water column. Dissolved oxygen concentrations will typically be lowest just before dawn, when concentrations at many sites would likely fall below the regulatory minimum requirement of $4 \mathrm{mg} / \mathrm{L}$. The variations in dissolved oxygen observed in natural waters are more pronounced in eutrophic waters, commonly being supersaturated in the late afternoon and dropping to near-anoxic conditions by early morning. If a significant area becomes rapidly anoxic, such that fish cannot escape, a massive fish kill can result. However, some fish kills may not be the result of low dissolved oxygen levels in the early morning, but rather high concentrations of ammonia in the late afternoon.

Prolific primary productivity in the late afternoon not only produces copious amounts of oxygen but also drives up the $\mathrm{pH}$ (makes the water more basic) which, in turn, can make the waters toxic if ammonia is present in the waters. In natural waters, benign ammonium ions $\left(\mathrm{NH}_{4}^{+}\right)$usually exist in equilibrium with ammonium hydroxide $\left(\mathrm{NH}_{4} \mathrm{OH}\right)$, a toxic compound. At a $\mathrm{pH}$ of 6 , the ratio of $\mathrm{NH}_{4}^{+}$: $\mathrm{NH}_{4} \mathrm{OH}$ is approximately $3,000: 1$; at a $\mathrm{pH}$ of 7.0 , about 300:1; and at $\mathrm{pH} 9.5$, about 1:1. The $\mathrm{pH}$ measured in Laguna San José has often exceeded 9.0.

In general, with the exception of the upper Río Piedras watershed, dissolved oxygen levels in the estuary system have improved over the last 10 years. The ranges of dissolved oxygen and $\mathrm{pH}$ values measured at selected quality of water monitoring stations in the lagoons of the San Juan Bay estuary system have been decreasing as has the frequency of measurements of waters supersaturated in dissolved oxygen. This is most evident in a general lowering of dissolved oxygen concentrations and saturation levels (fig. 16). This likely corresponds with decreased proliferation of photosynthetic algae in the estuary 


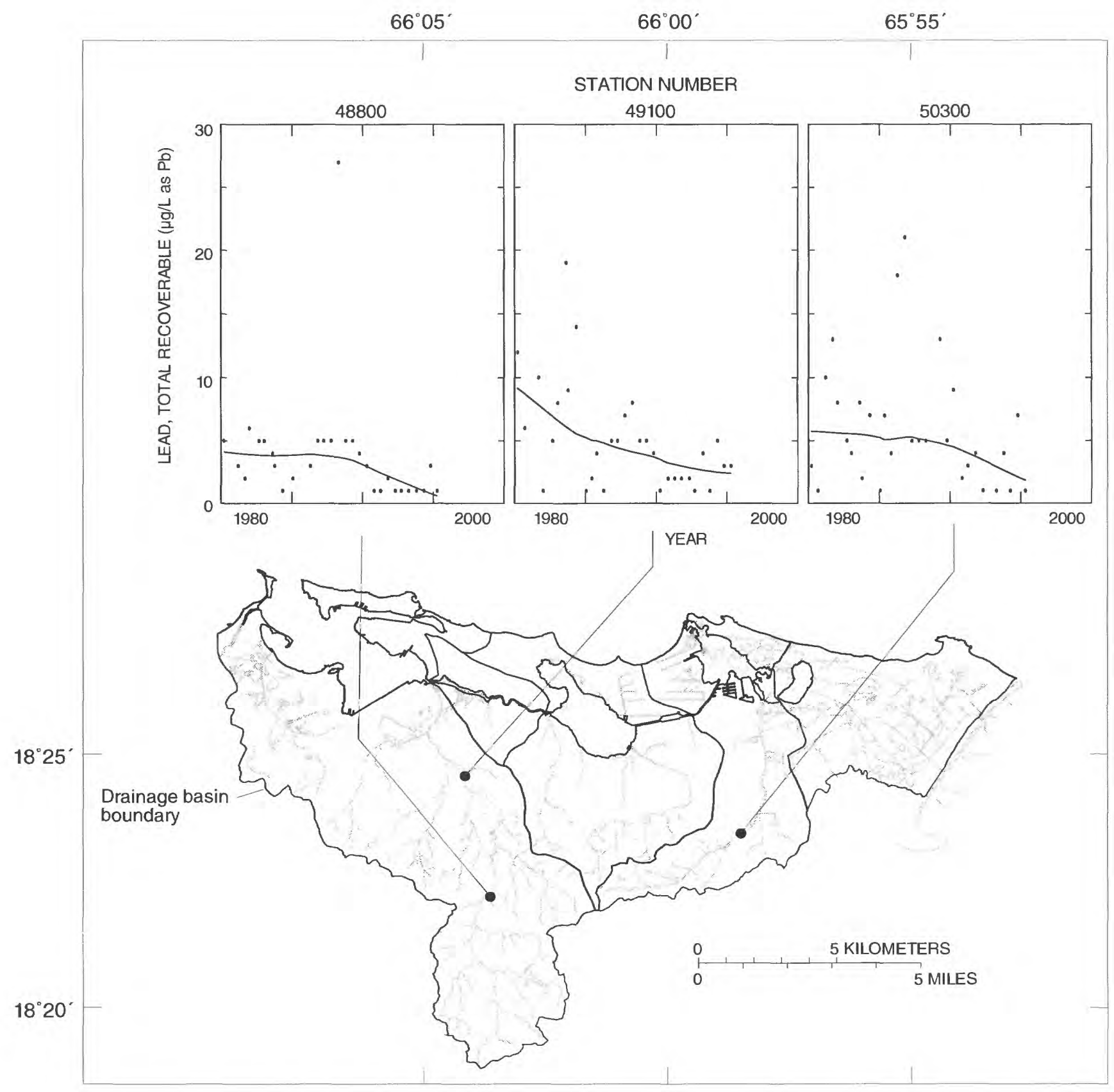

Figure 15. Total recoverable lead concentrations and trends at selected USGS-Commonwealth of Puerto Rico Cooperative program quality-of-water stations located in the San Juan Bay estuary system drainage basin Puerto Rico for the period 1980-95. The trend lines were produced using the LOWESS technique (Cleveland, 1979). 
system and is in agreement with the lowering of $\mathrm{pH}$ values in Laguna San José, Laguna La Torrecilla, and Laguna de Piñones. Population stress, defined as the number of people living in a watershed divided by the average discharge of water from the watershed, in the upper Río Piedras watershed has increased as urbanization has extended into the area. Dissolved oxygen levels are decreasing and the levels of dissolved ions and the reduced form of nitrogen $\left(\mathrm{NH}_{4}^{+}\right)$, have increased. The vast majority of dissolved oxygen measurements made by USGS personnel are performed during daylight hours, so the reported values represent the upper limit of the daily fluctuations.

\section{Macro-nutrients}

Orthophosphorus and the nitrogen species (nitrate, nitrite and total Kjeldahl nitrogen) are the primary anthropogenic contaminants related directly to the eutrophication of water bodies. As discussed above, excessive concentrations of these constituents lead to increased densities of planktonic and benthic algae (increase chlorophyll 'a') and in daily variations in dissolved oxygen concentrations and of $\mathrm{pH}$.

The most significant changes in nutrient concentrations during the past 20 years has been at Laguna San José, Laguna La Torrecilla, and Laguna de Piñones (fig. 17). Whereas the decline in nutrient concentrations at Laguna La Torrecilla and Laguna de Piñones can be related to the diversion of wastewater discharge to Quebrada Blasina from the Vistamar, Carolina, and Round Hills sewage treatment plants around 1985, the same cannot be inferred for Laguna San José. At Laguna San José the major sources of nutrients are related to domestic wastewater discharge from housing around Laguna Los Corozos and from discharge of raw sewage to the storm-water drainage system; the Baldorioty de Castro storm-water pumping station can be observed to operate almost continuously, discharging contaminated waters into northern Laguna San José even during dry periods (PREQB, 1984).

\section{Bacteriological Contamination}

Single determinations of fecal coliform concentrations met the PREQB water quality standards for SB and SC waters for all estuary system sites sampled during dry weather conditions in March 1995 (fig. 18) with the exception of the two Caño de Martín Peña sites (MPN501-270,000 col/100 mL; Martín Peña at Barbosa bridge - $610,000 \mathrm{col} / 100 \mathrm{~mL}$ ), the Bahía de San Juan site nearest to Caño de Martín Peña (San Juan Bay Pylon \#5-4,000 col/100 mL), and the Laguna San José site nearest to Caño de Martín Peña (San José Lagoon \#2-2,500 $\mathrm{col} / 100 \mathrm{~mL}$ ). None of the estuary system sites sampled during wet weather conditions in July 1995 met the water quality standards with the exception of the four sites in the Bahía de San Juan. The most significant increases were for sample sites in Laguna Los Corozos and Laguna San José (from 280 to $6,000 \mathrm{col} / 100 \mathrm{~mL}$ for the site in Laguna Los Corozos). This is probably caused by the discharge of two storm-water drainage pumps on the north shore of Laguna Los Corozos.

Quality of water samples obtained at three stream sites and seven estuary sites during the past 20 years indicate that domestic wastewater discharges to streams persist (fig. 19). Domestic wastewater is introduced through connections of sanitary sewage lines to storm-water drains, overflows from septic systems and sewer lines, and from direct discharges from unsewered areas. The only sample locations in the estuary system where the bacteriological contamination seems to have improved are within Laguna La Torrecilla and Laguna de Piñones; both lagoons were previously impacted by the discharge of wastewater treatment plant effluents to Quebrada Blasina.

It can be expected that the quality of water in the estuary system will improve as water pollution control measures continue to be implemented. Among the most important of these, to date, has been the diversion almost $70 \mathrm{Mgal} / \mathrm{d}$ of primary treated sewage (USACE, 1978) from the Bahía de San Juan to an ocean outfall that discharges north of Isla de Cabras. Similarly, the water quality of Quebrada Blasina, Laguna La Torrecilla, and Laguna de Piñones is expected to improve following the diversions of wastewater previously discharged into Quebrada Blasina. 


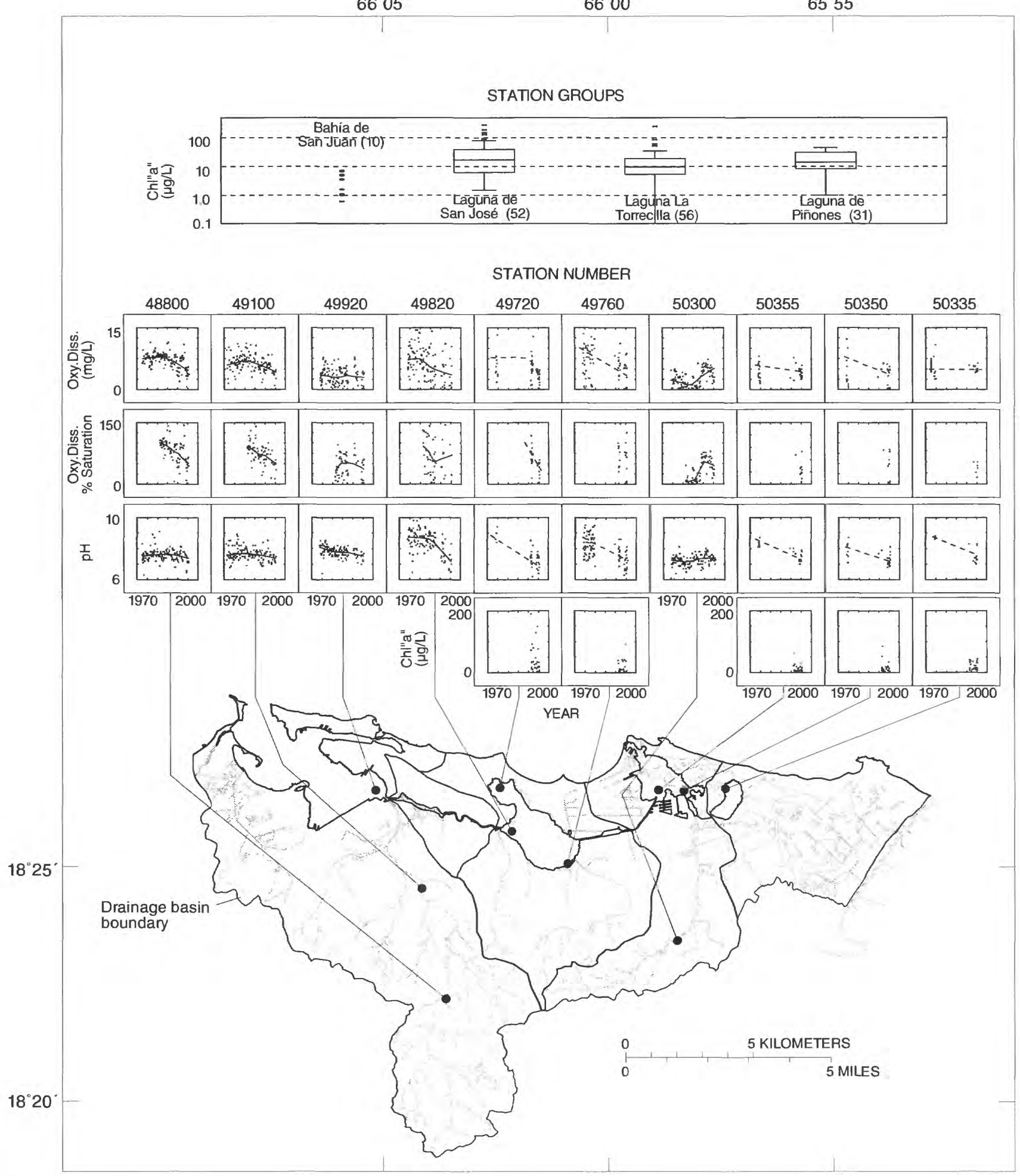

Figure 16. Dissolved oxygen, $\mathrm{pH}$, and chlorohyll'a' determinations and trends at selected USGSCommomwealth of Puerto RIco Cooperative program quality-of-water stations in the San Juan Bay estuary system, Puerto Rico, for the period 1970-95. The box plots at the top show the distribution of chlorophyll'a' values measured for groups of stations as identified in figure 10. The total number of samples included in the calculation of a box plot is given in parenthesis. For selected stations with sufficient data, a trend line was produced using the LOWESS technique (Cleveland, 1979). For stations with a significant hiatus in the data collection the rough trend is indicated with a dashed line. Note that small differences observed using the logarithmic scale for chlorophyll'a' (for the box plots) and $\mathrm{pH}$ (as defined) represent large differences in the absolute values. 


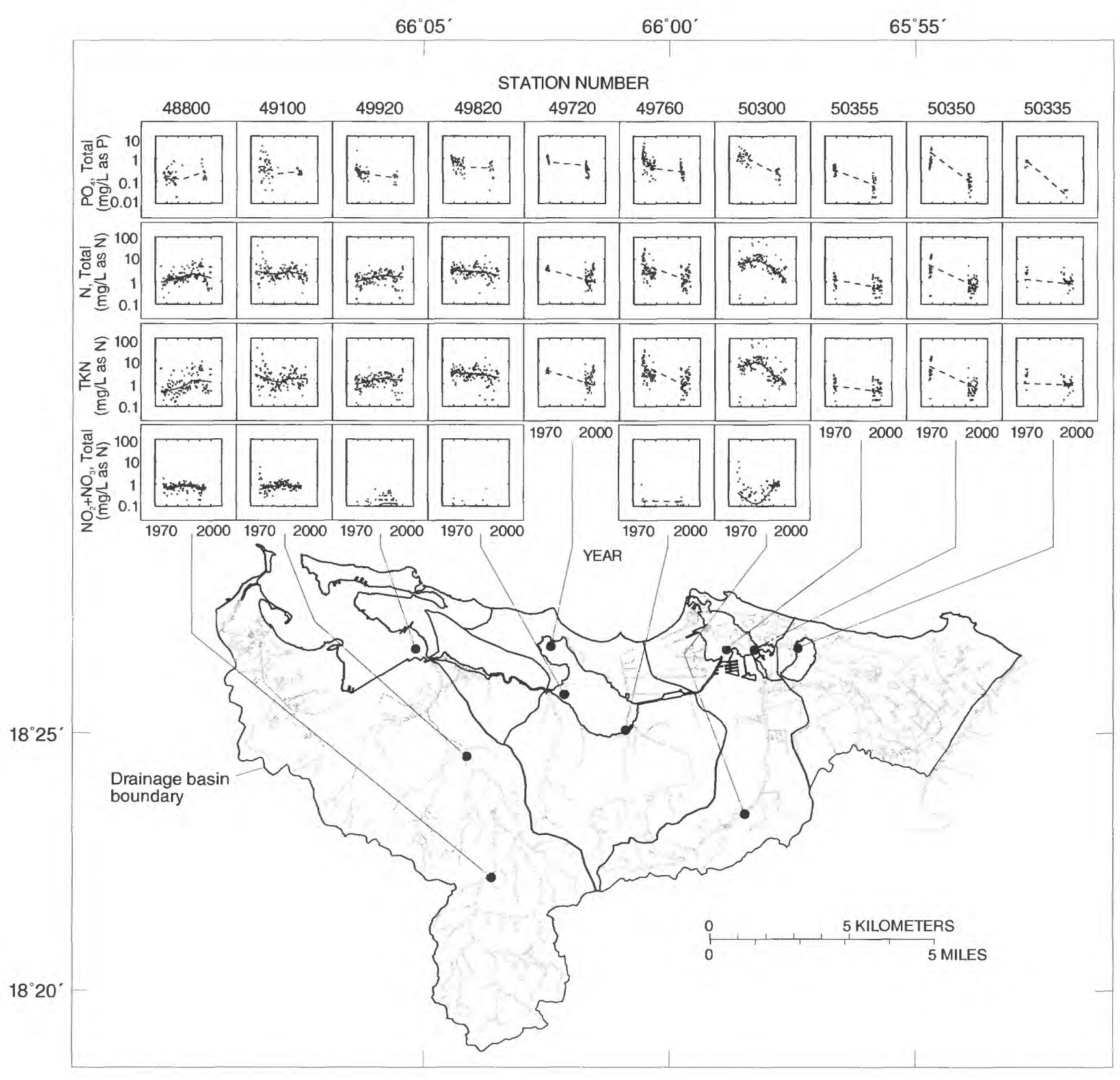

Figure 17. Total orthophosphorus, total nitrogen, total Kjeldahl nitrogen, and total nitrate + nitrite concentrations and trends at selected USGS-Coommonwealth of Puerto Rico Cooperative program qualityof-water stations in the San Juan Bay estuary system, Puerto Rico, for the period 1970-95. For selected stations with sufficient data, a trend line was produced using the LOWESS technique (Cleveland, 1979). For stations with a significant hiatus in the data collection the rough trend is indicated with a dashed line. Note that small differences observed using the logarithmic scale represent large differences in the absolute values. 


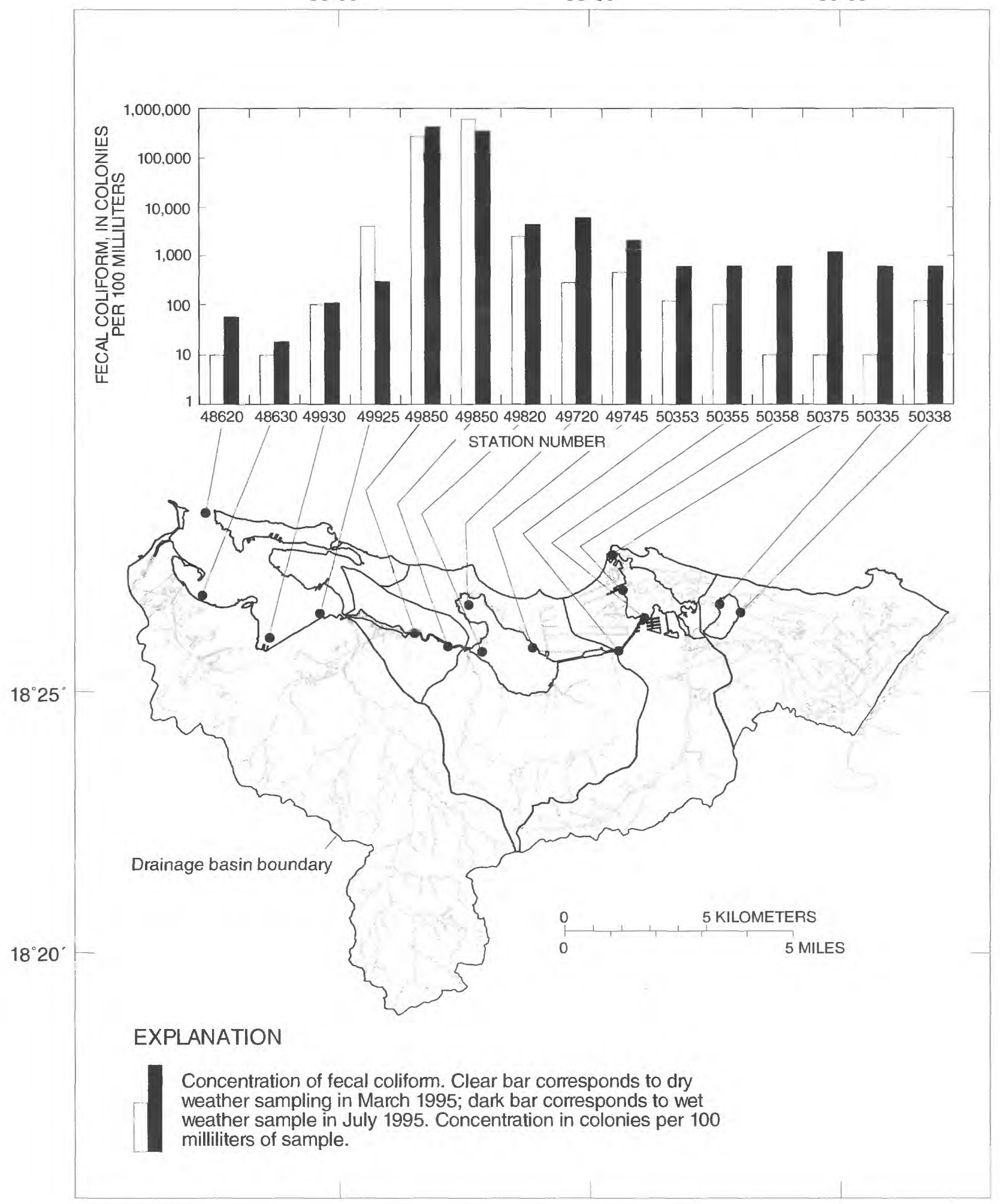

Figure 18. Fecal coliform counts obtained as part of the quality-of-water synoptic surveys conducted in the San Juan Bay estuary system, Puerto Rico, March and July 1995. Note that small differences observed using the logarithmic scale represent large differences in the abolute values. 


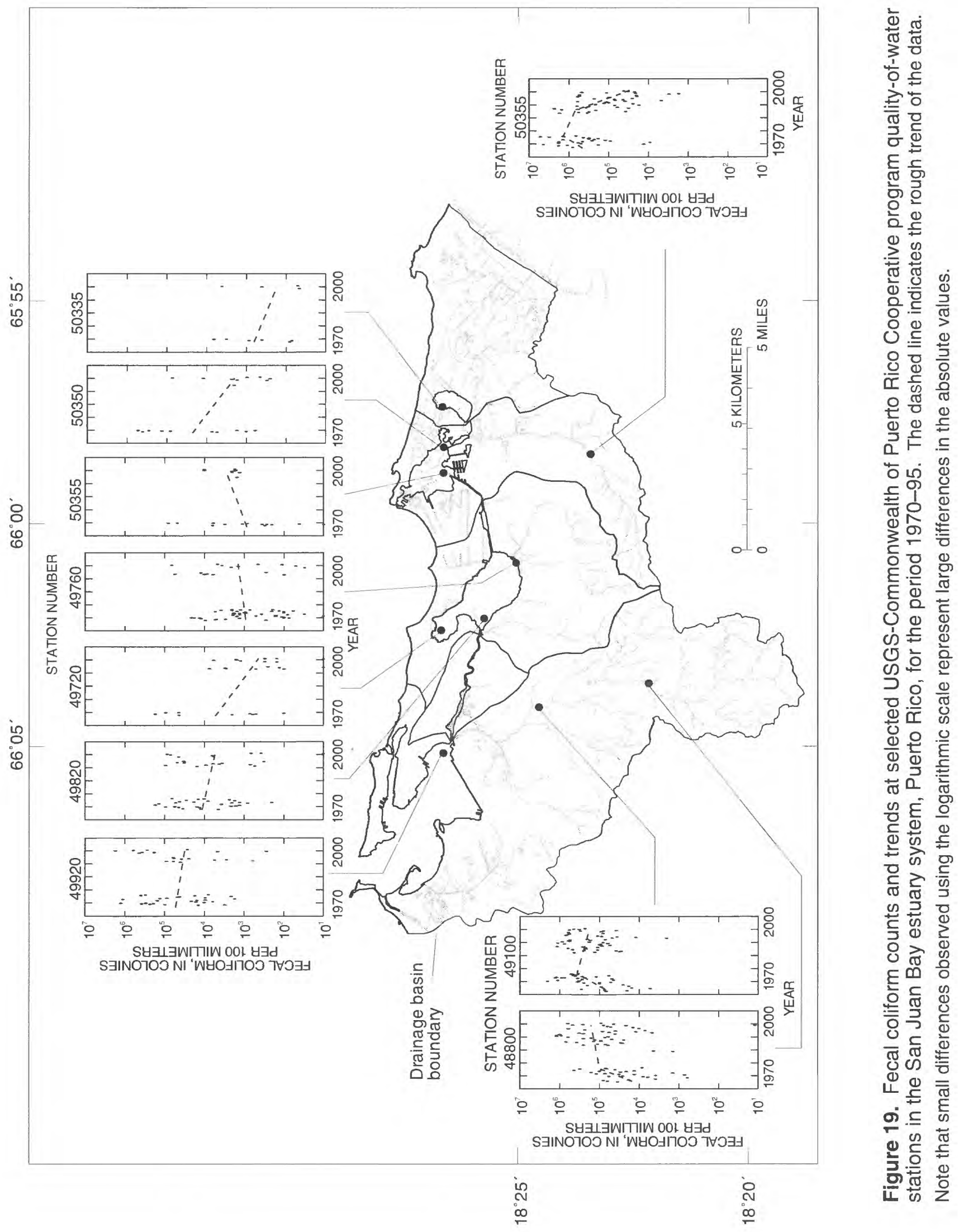




\section{Sediment Quality}

Anthropogenic effects on sediment quality are most evident for constituents used in the uplands of the watershed that are subsequently adsorbed onto sediments and transported into the tidal portions of the estuary. Among these are phosphorus (major source is fertilizer, detergents, and waste from food processing), PCB's (commonly used in electric transformers), dieldrin (used intensively on sugar cane crops), lead (leaded gasoline and paints), and mercury (electrical and mechanical components).

Organochlorine compounds entered the commercial market during the 1940's (PCB's, dieldrin, and DDT and metabolites). Their concentrations in surficial bottom sediments are expected to decrease as their use has been discontinued except for limited use of PCB's in sealed transformers. Data obtained in the estuary system indicate that of these toxic organic compounds the presence of PCB's in the bottom sediments Bahía de San Juan and the Laguna Los Corozos embayment of Laguna San José may persist at relatively high concentrations in the surficial bottom sediments for some time since sediment depositional rates average about $5 \mathrm{~cm}$ per decade. Also, it is possible that sources of PCB's within the Caño de Martín Peña drainage basin are still active. These results merit more detailed sampling of surficial bottom sediments within Bahía de San Juan, Caño de Martín Peña, and Laguna San José. In addition, surficial bottom sediment samples likely are merited at Laguna del Condado considering that a thermoelectric power plant existed within the eastern shoreline of the lagoon until about 1960.

\section{DISCUSSION}

The San Juan Bay estuary system is extremely compact and has a great deal of variability of water and sediment quality. The largest river in the estuary system is the Río Piedras, which has a drainage area (measured at its most downstream station) of $39.9 \mathrm{~km}^{2}$ and a mean discharge of $1.4 \mathrm{~m}^{3} / \mathrm{s}$. The concentrations of contaminants in the water represent stresses on the river that depend on the human population within a basin and the capacity (as measured by mean discharge) of the river to reduce the concentrations of contaminants by dilution (Moody and Battaglin, 1995). The population stress can be defined as the ratio of the population living upstream from a point in the river to the mean stream discharge at that point. Using 200,000 people for the population upstream of the Río Piedras gaging station, the population stress is approximately 140,000 people per cubic meter per second. The stress is even greater for water bodies with lower discharge such as Caño de Martín Peña and Laguna San José. For comparison, the highest population stress for the Mississippi River is that of the Illinois river tributary system with a value of 14,600 people per cubic meter per second (Moody and Battaglin, 1995). Restricted circulation is also a major factor in the continued deterioration of water quality in the San Juan Bay estuary system in general (USEPA, 1992), in Caño de Martín Peña (USACE, 1978), and in the mortalities of trees in the Bosque Estatal de Piñones (Jiménez and others, 1985).

Overall, the conditions in the San Juan Bay estuary system are improving. Dissolved oxygen levels in the Bahía de San Juan have increased after the waste stream previously discharged to the bay was diverted to an ocean outfall in 1985. Water quality in the Río Piedras drainage basin is degrading as the remaining vegetated slopes within the basin are urbanized. Sediment yields exceeding 14,000 $\mathrm{Mg} / \mathrm{km}^{2} / \mathrm{yr}$ equate to an average loss of $10 \mathrm{~cm}$ of soil per year over the entire uplands south of the Río Piedras near Río Piedras water-quality monitoring station (50048800). Coincident with the urbanization and increased population in the uplands, concentrations of dissolved solids, nutrients, and pathogens have increased while concentrations of dissolved oxygen have decreased. To the east, the water quality of the once extremely contaminated Quebrada Blasina has improved significantly resulting in improving conditions downstream in Laguna La Torrecilla and Laguna de Piñones. Caño de Martín Peña and Laguna San José contain significant quantities of lead, mercury, PCB's, and semi-volatile compounds in the sediment, reflecting both the population stress and the limited circulation of these water bodies.

Contaminated sediments deposited in Caño de Martín Peña and Laguna San José present a potential threat to human health through direct contact and through ingestion of harvested organisms. Toxic compounds sorbed onto sediments in eastern Caño de Martín Peña are largely prevented from entering the food chain because of the anoxic, abiotic conditions present there. Commonwealth and federal agencies are 
currently evaluating the feasibility of dredging the eastern part of Caño de Martín Peña. If dredging is carried out, hydraulically closing the eastern Caño de Martín Peña during operations may reduce the potential for negative impacts on the biota of western Caño de Martín Peña or western Laguna San José. Once removed and placed in an uplands disposal site or used to fill the deeper sections of the dredge pits, the contaminated material could be isolated from the ecosystem by capping it with a sufficiently thick blanket of clean material. If used to fill existing dredge pits in Laguna San José, Canal Suárez, or Laguna La Torrecilla, a thick cap of clean material could prevent reintroduction of buried contaminants into the lagoons by diffusion or bioturbation. The cleanup of contaminated sediments in Laguna San José will not be so straightforward, as the contaminants are spread out as a thin (less than $20-\mathrm{cm}$ layer) layer across the lagoon. However, sediments deposited in the lagoon in the future will likely be less toxic as contaminant loads are reduced and the overall circulation of the San Juan Bay estuary system is improved. Overall, the conditions of the San Juan Bay estuary system will continue to improve as contaminant loads from point and non-point sources are reduced and the natural circulation patterns are restored.

\section{SUMMARY}

More than 600,000 people live within the 240 square-kilometer drainage basin of the San Juan Bay estuary system, located on the north coast of Puerto Rico. This most densely populated area of the island is also home to an extensive and diverse ecosystem, including the largest mangrove forest on the island. During 1994 and 1995, the U.S. Geological Survey conducted a synoptic survey of the quality of water and bottom sediments in the San Juan Bay estuary system in cooperation with the U.S. Environmental Protection Agency and the Puerto Rico Department of Natural and Environmental Resources. Water quality was sampled in March and May 1995, corresponding to dry and wet weather conditions. Vertical profiles for temperature, specific conductance, $\mathrm{pH}$, and dissolved oxygen were recorded at 15 water-quality sites. Surface waters at the sites were analyzed for secchidisk transparency, color, turbidity, total suspended solids, total dissolved nitrate, total dissolved ammonia nitrogen, total orthophosphate, chlorophyll 'a' and 'b', and fecal-coliform bacteria. In December 1994 and
July 1995, surficial bottom sediments at nine sites and core samples from six sites were analyzed for grainsize distribution, concentration of total Kjeldahl nitrogen, total phosphorus, and total carbon. Core samples at six locations were analyzed for organochlorine compounds, trace elements, and semivolatile organic compounds contained in discrete depth intervals representing the depositional periods - 1925-49, 1950-74, and 1975-95. Average sedimentation rates used to approximate these intervals were determined by measuring the downcore activity of cesium-137, a radioisotope contained in nuclear-bomb fallout. Sedimentation rates ranged from about 0.24 centimeter per year ( 1 inch per decade) in Laguna de Piñones to about 3.9 centimeters per year (15 inches per decade) in Caño de Martín Peña.

After the rainfall event in July 1995, secchi-disk transparency was reduced from an average of 89 to 55 centimeters for five stations and increased from 90 to 108 centimeters for five stations. Turbidity increased from about 4 to about 8 nephelometric turbidity units. Concentrations of total suspended solids in the Bahía de San Juan were generally lower (less than 20 milligrams per liter) after the rainfall event in July 1995 then those measured during the dry weather conditions in March 1995 (greater than 30 milligrams per liter). During the March 1995 sampling, high energy waves were entering the bay and resuspending bottom sediments. Dissolved nutrient concentrations measured in March 1995 were not significantly different than those measured in July 1995. Nutrient concentrations were highest in Caño de Martín Peña (2.3 milligrams of ammonia as nitrogen per liter; 0.22 milligram of orthophosphate as phosphorus per liter), and Canal Suárez (0.14 milligram of nitrate as nitrogen per liter). Laguna San José was also enriched in nutrients. The most contaminated area, Caño de Martín Peña, had elevated ammonia concentrations and counts of fecal-coliform bacteria on the order of 100,000 colonies per 100 milliliters. Surface waters sampled at an incidental site near the discharge of sewage entering Caño de Martín Peña in March 1996 had a concentration of fecal coliform in excess of 2 million colonies per 100 milliliters. At none of the other sampled sites did fecal coliform concentrations exceed 6,000 colonies per 100 milliliters, nor did dissolved ammonia exceed 0.45 milligrams per liter. 
PCB's, the pesticide DDT (and metabolites DDD and DDE), a common plasticizing agent bis(2-ethylhexl) phthalate, lead, and mercury were the most abundant contaminants measured in the estuarine sediments during this study. At Caño de Martín Peña, the most contaminated site, the PCB concentrations increased from 12 micrograms per kilogram in the oldest strata to 380 micrograms per kilogram in the most recently deposited sediments (1975-95). DDT was used extensively from the 1940s through the end of the 1960s, and the concentrations of DDT and its metabolites (sum of DDT, DDD, and DDE), at the Caño de Martín Peña site were highest in the sediments deposited from 1950 to 1974,62 micrograms per kilogram, decreasing to 27 micrograms per kilogram in the period 1975-95. DDT and metabolites were below the detection level of 0.1 microgram per kilogram for the period 1925-49 for the coring sites in the Bahía de San Juan, Laguna Los Corozos, and Laguna La Torrecilla. Bis(2-ethylhexl) phthalate exceeded 20,000 micrograms per kilogram in the most recent strata of the Caño de Martín Peña core site, leachate from the PVC and other plastics contained in construction rubble commonly used for fill in the squatter communities being the most likely source. Lead increased at the Caño de Martín Peña core site from 30 micrograms per gram in the oldest strata to 750 micrograms per gram in the most recent strata; similarly, mercury increased from 0.16 to 4.7 micrograms per gram.

Analysis of data collected from 1970 to 1995 shows that since 1985, the quality of water in the San Juan Bay estuary system has improved. Since then, leaded gasoline has been phased out, and wastewater from local plants, previously discharged to inland waters, is now collected and routed to regional facilities for discharge to offshore ocean outfalls.

\section{REFERENCES}

Anderson, H.R., 1976, Ground water in the San Juan Metropolitan area, Puerto Rico: U.S. Geological Survey Water-Resources Investigations Report 75-41, $34 \mathrm{p}$.

Barber, L.B. II, Leenheer, J.A., Pereira, W.E., Noyes, T.I., Brown, G.K., Tabor, C.F., and Writer, J.H., 1995, Organic contamination of the Mississippi River from municipal and industrial wastewater, in Meade, R.H., ed., Contaminants in the Mississippi River, 1987-92: U.S. Geological Survey Circular 1133, p. 114-135.

Baudo, Renalto, Giesy, J.P., and Muntau, Herbert, eds., 1990, Sediments: Chemistry and toxicity of in-place pollutants: Ann Arbor, Michigan, Lewis Publishers, Inc., $405 \mathrm{p}$.

Benedetty, José, and Cruz, Hector, 1980, Sand study (Task 4.3): DNR Scientific Research Area, Division of Geology, Commonwealth of Puerto Rico, unnumbered.

Britton, L.J., Greeson, P.E. eds., 1987, Methods for collection and analysis of aquatic biological and microbiological samples, U.S. Geological Survey Techniques of Water-Resources Investigations, book 5, chap. A4, 363 p.

Bush, D.M., Webb, R.M.T., González-Liboy, José, Hyman, Lisbeth, and Neal, W.J., 1995, Living with the Puerto Rico shore: Durham, North Carolina, Duke University Press, 193 p.

Calvesbert, R.J., 1970, Climate of Puerto Rico and U.S. Virgin Islands, in Climatography of the United States No. 60-52; Climate of the States: Washington, D.C., U.S. Department of Commerce, Environmental Science Services Administration, Environmental Data Service, 29 p.

Chapman, P.M., 1989, Current approaches to developing sediment quality criteria: Environmental Toxicology and Chemistry, v. 8, p. 589-599.

Cintrón, Gilberto, Velázco-Domínguez, A.T., Webb, R.M., and Nichols, Maynard, 1984, Technical data base for the development of public policy regarding the exploitation of submarine sand deposits in Puerto Rico: Technical publication for the Puerto Rico Department of Natural Resources, $137 \mathrm{p}$.

Cleveland, W.S., 1979, Robust locally weighted regression and smoothing of scatterplots: Journal of American Statistical Association, v. 74, no. 368, p. 829-836.

Crusius, John, and Anderson, R.F., 1995, Evaluating the mobility of ${ }^{137} \mathrm{Cs},{ }^{239+240} \mathrm{Pu}$, and ${ }^{210} \mathrm{~Pb}$ from their distributions in laminated lake sediments: Journal of Paleolimnology, v. 13, p. 119-141. 
Díaz, P.L., Aquino, Zaida, Figueroa-Alamo, Carlos, Vachier, R.J., and Sánchez, A.V., 1996, Water Resources Data, Puerto Rico and the U.S. Virgin Islands, Water Year 1996: U.S. Geological Survey Water-Data Report PR-96-1, 564 p.

Di Toro, D.M., Zarba, C.S., and others, 1991, Pre-draft technical basis for establishing sediment quality criteria for non-ionic organic chemicals using equilibrium partitioning: Washington, D.C., Office of Science and Technology, Environmental Protection Agency.

Durham, R.W., and Joshi, S.R., 1980, Recent sedimentation rates, ${ }^{210} \mathrm{~Pb}$ fluxes, and particle settling velocities in Lake Huron, Laurentian Great Lakes: Chemical Geology, v. 31, p. 53-66.

Ellis, S.R., 1976, History of dredging and filling of lagoons in the San Juan area, Puerto Rico, U.S. Geological Survey Water-Resources Investigations Report 38-76, 25 p.

Ellis, S.R., and Gómez-Gómez, Fernando, 1976, Hydrologic characteristics of lagoons at San Juan, Puerto Rico, during a January 1974 tidal cycle: U.S. Geological Survey Water-Resources Investigations Report 38-75, 45 p.

Fishman, M.J., ed., 1993, Methods of analysis by the U.S. Geological Survey National Water Quality Laboratory -- Determination of inorganic and organic constituents in water and fluvial sediments: U.S. Geological Survey Open-File Report 93-125, 217 p.

Fishman, M.J., and Friedman, L.C., eds., 1989, Methods for determination of inorganic substances in water and fluvial sediments: U.S. Geological Survey Techniques of Water-Resources Investigations Report, book 5, chap. Al, 545 p.

Folk, R.L., 1980, Petrology of sedimentary rocks: Austin, Texas, Hemphill Publishing Company, 182 p.

Garbarino, J.R., Hayes, H.C., Roth, D.A., Antweiler, R.C., Brinton, T.I., and Taylor, H.E., 1995, Heavy metals in the Mississippi River, in Meade, R.H., ed., Contaminants in the Mississippi River, 1987-92: U.S. Geological Survey Circular 1133, p. 52-71.

Gómez-Gómez, Fernando, Quiñones, Ferdinand, and Ellis, S.R., 1983, Hydrologic characteristics of lagoons at San Juan, Puerto Rico, during and October 1974 tidal cycle: U.S. Geological Survey Open-File Report $82-349,34 \mathrm{p}$

Guy, H.P., 1969, Laboratory theory and methods for sediment analysis: U.S. Geological Survey Techniques of Water-Resources Investigations Report, book 5, chap. C1, $58 \mathrm{p}$.

Haire, W.J., 1975, Floods in the Carolina-Río Grande area, northeastern Puerto Rico: U.S. Geological Survey Hydrologic Investigations Atlas HA-533, 1 sheet.
Horowitz, A.J., 1985, A primer on trace metal-sediment chemistry: U.S. Geological Survey Water-Supply Paper 2277, 67 p.

Horowitz, A.J., Demas, C.R., Fitzgerald, K.K., Miller, T.L., and Rickert, D.A., 1994, U.S. Geological Survey protocol for the collection and processing of surfacewater samples for the subsequent determination of inorganic constituents in filtered water: U.S. Geological Survey Open-File Report 94-539, 57 p.

Jaagumagi, R., 1993, Development of the Ontario Provincial sediment quality guidelines for polycylclic aromatic hydrocarbons (PAH): Queen's Printer for Ontario, prepared for the Ontario Ministry of Environment and Energy, January 1994, 13 p.

1994, Development of the Ontario Provincial sediment quality guidelines for the PCB's and the organochlorine pesticides: Queen's Printer for Ontario, prepared for the Ontario Ministry of Environment and Energy, August 1993, 16 p.

Jiménez, J.A., Martínez, Ramón, and Encarnación, Luis, 1985, Massive tree mortality in a Puerto Rican mangrove forest: Caribbean Journal of Science, v. 21, p. 75-78.

Kaye, C.A., 1959a, Geology of the San Juan Metropolitan Area, Puerto Rico: U.S. Geological Survey Professional Paper 317-A, 48 p.

Kaye, C.A., 1959b, Shoreline features and quaternary shoreline changes, Puerto Rico: U.S. Geological Survey Professional Paper 317-B, 140 p.

Krishnaswami, S., Lal, D., Martin, J.M., and Maybeck, M., 1971, Geochronology of lake sediments: Earth and Planetary Science Letters, v. 11, p. 407-414.

Long, E.R., and Morgan, L.G., 1990, The potential for biological effects of sediment-sorbed contaminants tested in the National Status and Trends Program: Seattle, Washington, U.S. National Oceanic and Atmospheric Administration, Technical Memorandum NOS OMA 52, 77 p.

MacDonald, D.D., 1992, Development of an integrated approach to the assessment of sediment quality, Volume 1: In Florida. Volume 2: Supporting documentation: $101 \mathrm{p}$.

Marsh, S.P., 1992a, Analytical results for stream sediment and soil samples from the Commonwealth of Puerto Rico, lsla de Culebra, and lsla de Vieques: U.S. Geological Survey Open-File Report 92-353A, 8 p.

Marsh, S.P., 1992b, Analytical results for stream sediment and soil samples from the Commonwealth of Puerto Rico, lsla de Culebra, and lsla de Vieques: U.S. Geological Survey Open-File Report 92-353B, data on a 5.25 inch diskette.

McHenry, J.R., Ritchie, J.C., and Cooper, C.M., 1980, Rates of recent sedimentation in Lake Pepin: Water Resources Bulletin, v.16, no. 6, p. 1,049-1,056. 
Monroe, W.H., 1973, Geololgic map of the Bayamón quadrangle, Puerto Rico: U.S. Geological Survey Miscellaneous Geologic Investigations Map I-751, $1 \mathrm{pl}$.

1977, Geologic map of the Carolina quadrangle, Puerto Rico: U.S. Geological Survey Miscellaneous Investigations Series Map I-1054, 1 pl.

Moody, J.A., and Battaglin, W.A., 1995, Setting: Chemical character of the Mississippi River, in Meade, R.H., ed., Contaminants in the Mississippi River, 1987-92: U.S. Geological Survey Circular 1133, p. 31-39.

National Climatic Data Center, 1995, International Stations Meteorological Climate Summary, version 3.0: March 1995, Federal Climate Complex, Asheville, North Carolina, 1 compact disk.

Nieuwolt, S., 1977, Tropical climatology, an introduction to the climates of the low latitudes: John Wiley \& Sons, Ltd., London, England, 207 p.

PPB Environmental Laboratories, Inc., 1993, Final consolidated report for obtaining and analyzing sediment samples, water samples, and bioassay samples from San Juan Harbor, Puerto Rico: Submitted to U.S. Army Corps of Engineers, Jacksonville District, Jacksonville Florida, October 1, 1993, 104 p.

1995, Final report for obtaining and analyzing sediment samples, water samples, and bioassay samples from San Juan Harbor berthing area, Puerto Rico, Task Order 0044, Contract DACW1791D0004, Volume I of II: Submitted to the U.S. Army Corps of Engineers, Jacksonville District, Jacksonville Florida, January 27, 1995, 73 p.

Pease Jr., M.H., 1968, Geologic map of the Aguas Buenas quadrangle Puerto Rico: U.S. Geological Survey Miscellaneous Geologic Investigations Map I-479, $1 \mathrm{pl}$.

Poppe, L.J., Eliason, A.H., and Fredericks, J.J., 1985, APSAS - An Automated Particle Size Analysis System, U.S. Geological Survey Circular 963.

Puerto Rico Environmental Quality Board, 1984, 208 North Metro Region Project, Planning activities developed through U.S. EPA Grant Number P002140-01-9: approximately 500 p. unnumbered.

1990, Puerto Rico water-quality standards regulation, as amended, $100 \mathrm{p}$.

Puerto Rico Planning Board, 1976, The San Juan City Edges Project: Technical Report partially financed by the National Endowment for the Arts in Washington, D.C.; Grant Number A40-42-12B, 92 p.

Rodríguez, R.W., Webb, R.M.T., Bush, D.M., and Scanlon, K.M., 1992, Marine geologic map of the north insular shelf of Puerto Rico - Río de Bayamón to Río Grande de Loíza: U.S. Geological Survey Miscellaneous Investigations Series, Map I-2207, 2 pls.
Seguinot-Barbosa, José, 1983, Coastal modification and land transformation in the San Juan Bay are, Puerto Rico: Department of Geography and Anthropology, Louisiana State University, Baton Roque, Ph.D. dissertation, $302 \mathrm{p}$.

U.S. Army Corps of Engineers, 1978, Special Report on Martín Peña Canal: U.S. Army Engineer District, Jacksonville, Florida, $26 \mathrm{p}$.

U.S. Department of Commerce, 1991, 1990 Census of Population and Housing, Summary Population and Housing Characteristics, Puerto Rico: Puerto Rico, Bureau of the Census, 1990 CPH-1-53, 199 p.

U.S. Environmental Protection Agency, 1980, Guidelines for specification of disposal sites for dredged or fill material: Federal Register, December 24, 1980, v. 45(249), p. 85, 336-85, 357.

1992, Characterization of use impairments of the U.S. Virgin Islands and Puerto Rico: U.S. Environmental Protection Agency, Marine and Wetlands Protection Branch, December 1992, 196 p., app. A-E.

1993a, Sediment quality criteria for the protection of benthic organisms: Dieldrin: U.S. EPA Fact Sheet EPA-822-F-93-007, October 1993, 2 p.

$1993 \mathrm{~b}$, Sediment quality criteria for the protection of benthic organisms: Fluoranthene: U.S. EPA Fact Sheet EPA-822-F-93-004, October 1993, 2 p.

U.S. Environmental Protection Agency and U.S. Army Corps of Engineers, 1994, Evaluation of dredged material proposed for discharge in waters of the U.S. Testing Manual (Draft): June 1994, 172 p., app. A-G.

U.S. National Oceanic and Atmospheric Administration, 1989, Hurricane Hugo, Effects on Water Levels and Storm Surge Recorded at U.S. National Oceanic and Atmospheric Administration and National Ocean Service Water Level Stations: Data Report, National Ocean Service, October 20, 1989, 33 p.

Velázco-Domínguez, A.T., Webb, R.M.T, and Rodríguez, Jorge, 1986, Coastal Erosion and Protection Evaluation; Condado-Ocean Park to Isla Verde, Puerto Rico: Technical Publication for the Puerto Rico Department of Natural Resources.

Ward, J.R., and Harr, C.A., 1990, Methods for collection and processing of surface-water and bed-material samples for physical and chemical analysis: U.S. Geological Survey Open-File Report 90-140, 71 p.

Wershaw, R.L., Fishman, M.J., Grabbe, R.R., and Lowe, L.E., eds., 1987, Methods for the determination of organic substances in water and fluvial sediments: U.S. Geological Survey Techniques of Water-Resources Investigations of the United States Geological Survey, book 5 , chap. A3, $80 \mathrm{p}$. 


\section{APPENDIXES}


Appendix 1. In-situ determination of specific conductance, $\mathrm{pH}$, and dissolved oxygen levels with depth for sediment and water-quality sites sampled in March, May, and July 1995, San Juan Bay estuary system, Puerto Rico

[Sample locations are given in table 2 and shown on figures 7, 8, and 9. The water-quality sonde (Hydrolab) failed during the May sampling, therefore, a backup sonde (YSI temperature/specific conductance probe) with a 2 meter cable was used. Samples were obtained near the surface of the water column and analyzed for $\mathrm{pH}$ using a laboratory meter and for dissolved oxygen using Winkler titration; Dissolved oxygen determinations of $2.0 \mathrm{mg} / \mathrm{L}$ or less were not reliable, in as much as they were subject to the effects of hydrogen sulfide and did not duplicate values obtained using Winkler titration. These measurements are reported with a $J$ qualifier. Abbreviations: $\mathrm{m}$, meters; ${ }^{\circ} \mathrm{C}$, degrees Celsius; $\mu \mathrm{S} / \mathrm{cm}$, microsiemens per centimeter; $\mathrm{mg} / \mathrm{L}$, milligrams per liter; -, no data]

\begin{tabular}{|c|c|c|c|c|}
\hline $\begin{array}{l}\text { Depth } \\
(\mathrm{m})\end{array}$ & Temperature $\left({ }^{\circ} \mathrm{C}\right)$ & $\begin{array}{c}\text { Specific } \\
\text { conductance } \\
\left(\mu \mathrm{S} / \mathrm{cm} \text { at } 25^{\circ} \mathrm{C}\right)\end{array}$ & $\begin{array}{c}\mathrm{pH} \\
\text { (standard units) }\end{array}$ & $\begin{array}{l}\text { Dissolved oxygen } \\
(\mathrm{mg} / \mathrm{L})\end{array}$ \\
\hline
\end{tabular}

\begin{tabular}{|c|c|c|c|c|}
\hline \multicolumn{5}{|c|}{ San Juan Bay \#1 - Channel Entrance - 50048620 - depth 7.5 meters } \\
\hline \multicolumn{5}{|c|}{ March 15, 1995 - 9:15 am } \\
\hline 0.1 & 25.9 & 52500 & 7.3 & 5.2 \\
\hline 0.5 & 26.0 & 52500 & 7.3 & 5.2 \\
\hline 1.0 & 26.0 & 52500 & 7.0 & 5.2 \\
\hline 2.0 & 26.0 & 52500 & 7.2 & 5.2 \\
\hline 3.0 & 26.0 & 52500 & 7.2 & 5.7 \\
\hline 4.0 & 26.0 & 52600 & 7.2 & 5.0 \\
\hline 5.0 & 26.0 & 52500 & 7.3 & 5.0 \\
\hline 6.0 & 26.0 & 52600 & 7.3 & 5.0 \\
\hline 7.0 & 26.0 & 52700 & 7.3 & 4.9 \\
\hline \multicolumn{5}{|c|}{ May $18,1995-9: 50 \mathrm{am}$} \\
\hline 0.3 & 28.5 & 46000 & 8.4 & 3.8 \\
\hline 0.6 & 28.5 & 44500 & - & - \\
\hline 0.9 & 28.5 & 45500 & - & - \\
\hline 1.2 & 28.5 & 46800 & - & - \\
\hline 1.5 & 28.5 & 47100 & - & - \\
\hline 1.8 & 28.5 & 47400 & - & - \\
\hline \multicolumn{5}{|c|}{ San Juan Bay \#2 - Near Cataño Pyramid - 50048630 - depth 2.3 meters } \\
\hline \multicolumn{5}{|c|}{ March 15, 1995 - 9:45 am } \\
\hline 0.0 & 25.5 & 51900 & 7.2 & 4.7 \\
\hline 0.5 & 25.6 & 51800 & 7.3 & 4.7 \\
\hline 1.0 & 25.6 & 51700 & 7.3 & 4.7 \\
\hline 1.5 & 25.6 & 51800 & 7.1 & 4.6 \\
\hline 2.0 & 25.6 & 51800 & 7.2 & 4.6 \\
\hline
\end{tabular}

May 18, 1995 - 10:30 am; note temperatures read on analog scale read to nearest half degree

$\begin{array}{llllll}0.3 & 30.0 & 46800 & 8.3 & 7 \\ 0.6 & 29.0 & 47000 & - & - \\ 0.9 & 29.0 & 47000 & - & - \\ 1.2 & 29.0 & 47000 & - & - \\ 1.5 & 29.5 & 48000 & - & -\end{array}$

July $19,1995-8: 30$ am

$\begin{array}{lllll}0.1 & 28.6 & 54800 & 7.9 & 5.5 \\ 0.2 & 28.6 & 54800 & 7.9 & 5.5 \\ 0.4 & 28.6 & 54700 & 7.9 & 5.5 \\ 0.6 & 28.6 & 54600 & 7.9 & 5.4 \\ 0.8 & 54600 & 7.9 & 5.4 \\ 1.0 & 28.6 & 54800 & 7.9 & 5.3\end{array}$


Appendix 1. In-situ determination of specific conductance, $\mathrm{pH}$, and dissolved oxygen levels with depth for sediment and water quality sites sampled in March, May, and July 1995, San Juan Bay estuary system, Puerto Rico-Continued

\begin{tabular}{ccccc}
\hline $\begin{array}{c}\text { Depth } \\
(\mathrm{m})\end{array}$ & Temperature $\left({ }^{\circ} \mathrm{C}\right)$ & $\begin{array}{c}\text { Specific } \\
\text { conductance } \\
\left(\mu \mathrm{S} / \mathrm{cm} \text { at } 25^{\circ} \mathrm{C}\right)\end{array}$ & $\begin{array}{c}\mathrm{pH} \\
\text { (standard units) }\end{array}$ & $\begin{array}{c}\text { Dissolved oxygen } \\
(\mathrm{mg} / \mathrm{L})\end{array}$ \\
\hline 1.2 & 28.8 & 55000 & 7.9 & 5.3 \\
1.4 & 28.8 & 55300 & 7.9 & 5.1 \\
1.6 & 28.8 & 55300 & 7.9 & 5.1 \\
1.8 & 28.8 & 55200 & 7.9 & 4.9 \\
2.0 & 28.8 & 55200 & 7.9 & 4.8
\end{tabular}

San Juan Bay \#4 - Southern Bay - 50049930 - depth 11.8 meters

March 15, 1995 - 10:15 am

\begin{tabular}{|c|c|c|c|c|}
\hline 0.1 & 26.5 & 52400 & 7.2 & 5.0 \\
\hline 1.0 & 26.6 & 52400 & 7.2 & 5.0 \\
\hline 2.0 & 26.6 & 52400 & 7.3 & 4.8 \\
\hline 3.0 & 26.6 & 52400 & 7.3 & 4.7 \\
\hline 4.0 & 26.6 & 52500 & 7.3 & 4.5 \\
\hline 5.0 & 26.5 & 52400 & 7.3 & 4.5 \\
\hline 6.0 & 26.4 & 52500 & 7.3 & 4.1 \\
\hline 7.0 & 26.3 & 52400 & 7.3 & 4.1 \\
\hline 8.0 & 26.2 & 52600 & 7.3 & 4.1 \\
\hline 9.0 & 26.1 & 52500 & 7.2 & 4.2 \\
\hline 10.0 & 26.1 & 52500 & 7.2 & 4.2 \\
\hline 11.0 & 26.1 & 52500 & 7.2 & 4.2 \\
\hline \multicolumn{5}{|c|}{$18,1995-11: 25 \mathrm{am}$} \\
\hline 0.3 & 29.8 & 49500 & 8.2 & 2.2 \\
\hline 0.6 & 30.0 & 49500 & - & - \\
\hline 0.9 & 29.5 & 49510 & - & - \\
\hline 1.2 & 29.0 & 48500 & - & - \\
\hline 1.5 & 28.5 & 48000 & - & - \\
\hline 1.8 & 28.8 & 48000 & - & - \\
\hline
\end{tabular}

July $19,1995-9: 10$ am

$\begin{array}{lllll}0.1 & 29.9 & 55500 & 7.9 & 5.0 \\ 0.5 & 30.1 & 55500 & 7.9 & 5.0 \\ 1.0 & 30.0 & 55700 & 7.9 & 4.9 \\ 1.5 & 29.8 & 55700 & 7.9 & 4.8 \\ 2.0 & 29.8 & 55700 & 7.9 & 4.8 \\ 2.5 & 55600 & 7.9 & 4.8 \\ 3.0 & 29.7 & 55700 & 7.9 & 4.9 \\ 3.5 & 29.7 & 55600 & 7.9 & 4.8 \\ 4.0 & 29.7 & 55700 & 7.9 & 4.9 \\ 4.5 & 29.7 & 55600 & 7.9 & 4.8 \\ 5.0 & 29.7 & 55600 & 7.9 & 4.9 \\ 5.5 & 29.7 & 55600 & 7.9 & 4.9 \\ 6.0 & 29.7 & 55600 & 7.8 & 4.8 \\ 6.5 & 29.7 & 55700 & 7.8 & 4.8 \\ 7.0 & 29.7 & 55600 & 7.8 & 4.8 \\ 7.5 & 29.7 & 55700 & 7.8 & 4.8 \\ 8.0 & 29.7 & 55700 & 7.9 & 4.8\end{array}$


Appendix 1. In-situ determination of specific conductance, $\mathrm{pH}$, and dissolved oxygen levels with depth for sediment and water quality sites sampled in March, May, and July 1995, San Juan Bay estuary system, Puerto Rico-Continued

\begin{tabular}{ccccc}
\hline $\begin{array}{c}\text { Depth } \\
(\mathrm{m})\end{array}$ & Temperature $\left({ }^{\circ} \mathrm{C}\right)$ & $\begin{array}{c}\text { Specific } \\
\text { conductance } \\
\left(\mu \mathrm{S} / \mathrm{cm} \text { at } 25^{\circ} \mathrm{C}\right)\end{array}$ & $\begin{array}{c}\mathrm{pH} \\
(\text { standard units })\end{array}$ & $\begin{array}{c}\text { Dissolved oxygen } \\
(\mathrm{mg} / \mathrm{L})\end{array}$ \\
\hline 8.5 & 29.6 & 55700 & 7.9 & 4.7 \\
9.0 & 29.6 & 55700 & 7.9 & 4.7 \\
9.5 & 29.6 & 55700 & 7.9 & 4.7 \\
10.0 & 29.5 & 55700 & 7.9 & 4.7 \\
10.5 & 29.5 & 55700 & 7.9 & 4.7 \\
11.0 & 29.5 & 55700 & 7.9 & 4.6 \\
11.5 & 29.5 & 55700 & 7.9 & 4.6
\end{tabular}

SJN600 - San Juan Bay Core Site - 50049935 - depth 3.7 meters

July 19, 1995 - 9:50 am

$\begin{array}{lllll}0.1 & 29.3 & 55500 & 7.9 & 4.9 \\ 0.5 & 55500 & 7.9 & 5.0 \\ 1.0 & 29.3 & 55600 & 7.9 & 5.1 \\ 1.5 & 55500 & 7.9 & 5.2 \\ 2.0 & 29.3 & 55600 & 7.9 & 5.0 \\ 2.5 & 29.3 & 55600 & 7.9 & 5.0 \\ 3.0 & 29.3 & 55600 & 7.9 & 4.9\end{array}$

San Juan Bay Pylon \#5 - Near old outfall in eastern part of Bay - 50049925 - depth 3.1 meters

March 15, 1995 - 1I:45 am

$\begin{array}{lll}0.1 & 26.0 & 49800 \\ 0.5 & 26.0 & 51800 \\ 1.0 & 25.9 & 52300 \\ 1.5 & 25.9 & 52400 \\ 2.0 & 25.9 & 52400 \\ 2.5 & 25.9 & 52400 \\ 3.0 & 25.9 & 52500\end{array}$

$49800 \quad 7.3 \quad 5.4$

$\begin{array}{lll} & 7800 & 7.4\end{array}$

$\begin{array}{lll}52300 & 7.3 & 4.4\end{array}$

$52400 \quad 7.3 \quad 4.2$

$\begin{array}{lll}52400 & 7.3 & 4.2\end{array}$

$52400 \quad 7.3 \quad 4.1$

$52500-7.3-4.1$

March 15, 1995 - 11:50 am

$\begin{array}{lll}0.1 & 26.0 & 50200 \\ 0.5 & 26.0 & 51200 \\ 1.0 & 26.0 & 52200 \\ 1.5 & 25.9 & 52200 \\ 2.0 & 25.9 & 52300 \\ 2.5 & 25.9 & 52200 \\ 3.0 & 25.9 & 52200 \\ 8,1995-11: 50 \text { am } & & \\ 0.3 & 29.8 & 47000 \\ 0.6 & 29.5 & 47800 \\ 0.9 & 29.5 & 46500 \\ 1.2 & 29.5 & 48000 \\ 1.5 & 29.5 & 48000 \\ 1.8 & 29.5 & 48500\end{array}$

July $19,1995-12: 00$ pm

$\begin{array}{lll}0.1 & 29.4 & 55100 \\ 0.5 & 29.4 & 55100 \\ 1.0 & 29.4 & 55100\end{array}$

8.0

8.0

8.0
9

5.0

1

2

4.9 
Appendix 1. In-situ determination of specific conductance, $\mathrm{pH}$, and dissolved oxygen levels with depth for sediment and water quality sites sampled in March, May, and July 1995, San Juan Bay estuary system, Puerto Rico-Continued

\begin{tabular}{ccccc}
\hline $\begin{array}{c}\text { Depth } \\
(\mathrm{m})\end{array}$ & Temperature $\left({ }^{\circ} \mathrm{C}\right)$ & $\begin{array}{c}\text { Specific } \\
\text { conductance } \\
\left(\mu \mathrm{S} / \mathrm{cm} \text { at } 25^{\circ} \mathrm{C}\right)\end{array}$ & $\begin{array}{c}\mathrm{pH} \\
(\text { standard units })\end{array}$ & $\begin{array}{c}\text { Dissolved oxygen } \\
(\mathrm{mg} / \mathrm{L})\end{array}$ \\
\hline 1.5 & 29.2 & 55100 & 8.0 & 5.1 \\
2.0 & 29.2 & 55200 & 7.9 & 5.1 \\
2.5 & 29.2 & 55400 & 7.9 & 5.0 \\
3.0 & 29.2 & 55500 & 7.9 & 5.0 \\
3.5 & 29.2 & 55500 & 7.9 & 5.0
\end{tabular}

MPN500 - Martín Peña Core Site - 50049850 - depth 0.7 meters

March 15, 1995 - 12:30 pm

$\begin{array}{lllll}0.1 & 27.2 & 31900 & 6.8 & 1.8 \mathrm{~J} \\ 0.5 & 27.5 & 33000 & 6.6 & 0.8 \mathrm{~J}\end{array}$

March 15, $1995-12: 35 \mathrm{pm}$

$\begin{array}{rrrrr}0.1 & 31500 & 6.6 & 0.8 \mathrm{~J} \\ 0.5 & 27.4 & 32500 & 6.8 & 1.7 \mathrm{~J}\end{array}$

May $18,1995-12: 30 \mathrm{pm}$

$\begin{array}{lllcl}0.3 & 30.0 & 26800 & 7.3 & 0.2 \\ 0.6 & 29.5 & 44500 & - & - \\ 1995-12: 40 \mathrm{pm} & & & 7.2 & 0.9 \mathrm{~J} \\ 0.1 & 31.6 & 26800 & 7.1 & 2.0 \mathrm{~J} \\ 0.2 & 31.5 & 38000 & 7.4 & 0.4 \mathrm{~J} \\ 0.5 & 30.4 & 52500 & \end{array}$

Martín Peña at Barbosa Bridge - 50049840 - 0.8 meters

March 15, 1995 - 1:20 pm

$\begin{array}{lllll}0.1 & 25.9 & 19400 & 6.3 & 0.4 \mathrm{~J} \\ 0.6 & 19400 & 6.3 & 0.5 \mathrm{~J}\end{array}$

May 18. $1995-1: 05 \mathrm{pm}$ - Measurements made approximately 100 meters to west of bridge

$\begin{array}{lllll}0.2 & 29.5 & 18200 & 7.4 & 0.4 \mathrm{~J} \\ 0.3 & 30.2 & 19000 & - & - \\ 0.5 & 30.2 & 19200 & - & - \\ 0.6 & 30.1 & 19500 & - & - \\ 0.8 & 30.0 & 19500 & - & - \\ 0.9 & 30.0 & 19500 & - & - \\ 1.2 & 30.0 & 19500 & - & \end{array}$

July $20,1995-12: 00 \mathrm{pm}$

$\begin{array}{lllll}0.1 & 30.2 & 20000 & 7.2 & 1.3 \mathrm{~J} \\ 0.2 & 30.2 & 20000 & 7.2 & 1.3 \mathrm{~J} \\ 0.4 & 30.2 & 20000 & 7.2 & 1.3 \mathrm{~J} \\ 0.6 & 30.3 & 20000 & 7.2 & 1.4 \mathrm{~J}\end{array}$

San José Lagoon \#2 - South of Isla Guachinanga near Martín Peña - 50049820 - depth 1.0 meter

March 16, 1995 - 8:45 am

$\begin{array}{lllll}0.1 & 24.3 & 27600 & 6.9 & 3.6 \\ 0.5 & 24.3 & 27600 & 6.8 & 3.6 \\ 0.7 & 24.4 & 27700 & 6.8 & 3.6\end{array}$

May $17,1995-12: 50 \mathrm{pm}$

$\begin{array}{lllcl}0.3 & 29.8 & 19700 & 8.9 & 14.4 \\ 0.6 & 29.9 & 19800 & - & -\end{array}$


Appendix 1. In-situ determination of specific conductance, $\mathrm{pH}$, and dissolved oxygen levels with depth for sediment and water quality sites sampled in March, May, and July 1995, San Juan Bay estuary system, Puerto Rico-Continued

\begin{tabular}{|c|c|c|c|c|}
\hline $\begin{array}{l}\text { Depth } \\
(\mathrm{m})\end{array}$ & Temperature $\left({ }^{\circ} \mathrm{C}\right)$ & $\begin{array}{c}\text { Specific } \\
\text { conductance } \\
\left(\mu \mathrm{S} / \mathrm{cm} \text { at } 25^{\circ} \mathrm{C}\right)\end{array}$ & $\begin{array}{c}\mathrm{pH} \\
\text { (standard units) }\end{array}$ & $\begin{array}{l}\text { Dissolved oxygen } \\
(\mathrm{mg} / \mathrm{L})\end{array}$ \\
\hline 0.9 & 29.9 & 27500 & - & - \\
\hline \multicolumn{5}{|c|}{ San José Lagoon \#3 - Los Corozos -50049720 - depth 1.5 meters } \\
\hline \multicolumn{5}{|c|}{ March 16, $1995-8: 25$ am } \\
\hline 0.1 & 24.4 & 28300 & 7.1 & 6.6 \\
\hline 0.5 & 24.4 & 28200 & 7.2 & 6.4 \\
\hline 1 & 24.4 & 28200 & 7.1 & 6.3 \\
\hline 1.5 & 24.5 & 28500 & 7.3 & 7.0 \\
\hline \multicolumn{5}{|c|}{ May $17,1995-12: 35 \mathrm{pm}$} \\
\hline 0.3 & 29.8 & 19000 & 8.7 & 13.2 \\
\hline 0.6 & 30.2 & 22500 & - & - \\
\hline 0.9 & 30.2 & 29500 & - & - \\
\hline 1.2 & 30.2 & 31200 & - & - \\
\hline 1.5 & 30.0 & 32500 & - & - \\
\hline 1.8 & 30.0 & 34400 & - & - \\
\hline
\end{tabular}

CRZ400 - Los Corozos Core Site - 50049710 - depth 2.0 meters July 18, 1995 - 3:00 pm

$\begin{array}{lll}0.1 & 29.7 & 25900 \\ 0.2 & 29.8 & 25900 \\ 0.4 & 29.8 & 25900 \\ 0.6 & 29.8 & 25900 \\ 0.8 & 29.8 & 26000 \\ 1 & 29.8 & 26000 \\ 1.2 & 29.8 & 25900 \\ 1.4 & 29.8 & 26000 \\ 1.6 & 29.8 & 25900 \\ 1.7 & 29.8 & 25900\end{array}$

$\begin{array}{ll}8.1 & 6.1 \\ 8.1 & 5.7 \\ 8.1 & 5.6 \\ 8.1 & 5.6 \\ 8.1 & 5.6 \\ 8.1 & 5.5 \\ 8.1 & 5.4 \\ 8.0 & 4.4 \\ 8.0 & 4.7 \\ 8.0 & 5.1\end{array}$

SJS300 - San José Core Site - 50049755 - depth 1.9 meters July $18,1995-2: 10 \mathrm{pm}$

$\begin{array}{lllll}0.1 & 29.6 & 27500 & 7.7 & 4.6 \\ 0.5 & 29.6 & 27400 & 7.7 & 4.4 \\ 0.8 & 29.7 & 27500 & 7.7 & 3.4 \\ 1 & 29.8 & 27700 & 7.6 & 3.3 \\ 1.2 & 29.8 & 27700 & 7.6 & 3.3 \\ 1.4 & 29.9 & 27700 & 7.6 & 3.1 \\ 1.6 & 30.1 & 27900 & 7.5 & 0.9 \text { J }\end{array}$

Laguna Gardens - San José Lagoon - 50049745 - depth 4.0 meters

March 16, 1995 - 9:00 am

$\begin{array}{lllll}0.1 & 24.5 & 27800 & 7.9 & 8.4 \\ 0.5 & 28100 & 7.8 & 7.6 \\ 1 & 24.5 & 28100 & 7.5 & 6.2 \\ 2 & 24.5 & 38400 & 7.0 & 0.7 \mathrm{~J} \\ 3 & 26.8 & 43200 & 6.4 & 0.4 \mathrm{~J} \\ 4 & 27.3 & 44500 & 6.3 & 0.3 \mathrm{~J} \\ 3 & 27.6 & 43500 & 6.3 & 0.3 \mathrm{~J}\end{array}$


Appendix 1. In-situ determination of specific conductance, $\mathrm{pH}$, and dissolved oxygen levels with depth for sediment and water quality sites sampled in March, May, and July 1995, San Juan Bay estuary system, Puerto Rico-Continued

\begin{tabular}{ccccc}
\hline $\begin{array}{c}\text { Depth } \\
(\mathrm{m})\end{array}$ & Temperature $\left({ }^{\circ} \mathrm{C}\right)$ & $\begin{array}{c}\text { Specific } \\
\text { conductance } \\
\left(\mu \mathrm{S} / \mathrm{cm} \text { at } 25^{\circ} \mathrm{C}\right)\end{array}$ & $\begin{array}{c}\mathrm{pH} \\
(\text { standard units })\end{array}$ & $\begin{array}{c}\text { Dissolved oxygen } \\
(\mathrm{mg} / \mathrm{L})\end{array}$ \\
\hline 2 & 27.7 & 39800 & 6.7 & $0.4 \mathrm{~J}$ \\
1.5 & 25.1 & 30200 & 6.8 & 2.6 \\
1 & 24.6 & 28300 & 7.1 & 5.4 \\
0.5 & 24.6 & 28200 & 7.8 & 7.4 \\
0.1 & 24.7 & 27700 & 7.7 & 7.9 \\
May $17,1995-12: 10 \mathrm{pm}$ & & & & - \\
0.1 & 29.2 & 24300 & 8.2 & - \\
0.3 & 30.0 & 27200 & - & - \\
0.6 & 30.0 & 28000 & - & - \\
0.9 & 30.0 & 30100 & - & - \\
1.2 & 30.0 & 31300 & - & - \\
1.5 & 30.0 & 32000 & - & - \\
1.8 & 30.0 & 34200 & - & - \\
2.1 & 30.0 & 37800 & - & \\
\hline
\end{tabular}

July 20, $1995-10: 45$ am

$\begin{array}{lll}0.1 & 30.4 & 27500 \\ 0.5 & 30.2 & 27800 \\ 1 & 30.2 & 27800 \\ 1.5 & 30.2 & 28100 \\ 2 & 31.0 & 41200 \\ 2.5 & 31.1 & 42800 \\ 3 & 30.8 & 43600 \\ 3.5 & 30.8 & 44100 \\ 4 & 30.7 & 44500 \\ 4.2 & 30.6 & 44500\end{array}$

$\begin{array}{ll}7.7 & 5.4 \\ 7.6 & 4.8 \\ 7.6 & 4.8 \\ 7.5 & 3.4 \\ 7.5 & 0.5 \mathrm{~J} \\ 7.1 & 0.4 \mathrm{~J} \\ 6.9 & 0.4 \mathrm{~J} \\ 6.9 & 0.4 \mathrm{~J} \\ 6.9 & 0.4 \mathrm{~J} \\ 6.9 & 0.4 \mathrm{~J}\end{array}$

Suárez Canal at Hwy 26 - 50050353 - depth 1.0 meter

March 16, 1995 - 9:45 am

$\begin{array}{lllll}0.1 & 25.4 & 41600 & 7.4 & 4.9 \\ 0.8 & 25.6 & 51700 & 7.5 & 3.5\end{array}$

May 17, $1995-11: 45$ am
0.1

29.7

30500

8.0

1.9

July $20,1995-10: 25$ am *

$\begin{array}{lll}0.1 & 30.3 & 29800 \\ 0.5 & 30.2 & 30400 \\ 1 & 30.7 & 37600 \\ 1.5 & 30.8 & 41000 \\ 2 & 30.4 & 42000 \\ 2.5 & 30.4 & 42500 \\ 3 & 30.4 & 42700\end{array}$

$\begin{array}{ll}7.8 & 6.9 \\ 7.7 & 4.8 \\ 7.4 & 2.7 \\ 7.4 & 1.2 \\ 7.5 & 2.5 \\ 7.6 & 3.4 \\ 7.6 & 2.7\end{array}$

*Note: Sampled about 100 meters to west of bridge where area is deeper and fine sediments are deposited on bottom

Torrecilla Lagoon \#3 -Near Vista Mar - Southern Lagoon - 50050355 - depth 2.2 meters

March 16, 1995 - 10:00 am

$$
0.1
$$

24.9

46700

7.6

4.5 
Appendix 1. In-situ determination of specific conductance, $\mathrm{pH}$, and dissolved oxygen levels with depth for sediment and water quality sites sampled in March, May, and July 1995, San Juan Bay estuary system, Puerto Rico-Continued

\begin{tabular}{ccccc}
\hline $\begin{array}{c}\text { Depth } \\
(\mathrm{m})\end{array}$ & Temperature $\left({ }^{\circ} \mathrm{C}\right)$ & $\begin{array}{c}\text { Specific } \\
\text { conductance } \\
\left(\mu \mathrm{S} / \mathrm{cm} \text { at } 25^{\circ} \mathrm{C}\right)\end{array}$ & $\begin{array}{c}\mathrm{pH} \\
(\text { standard units })\end{array}$ & $\begin{array}{c}\text { Dissolved oxygen } \\
(\mathrm{mg} / \mathrm{L})\end{array}$ \\
\hline 0.5 & 25.0 & 46800 & 7.6 & 4.9 \\
1 & 25.0 & 51700 & 7.6 & 4.7 \\
1.5 & 25.2 & 53300 & 7.6 & 4.4 \\
2 & 25.0 & 53800 & 7.6 & 1.7 \\
May $17,1995-11: 25$ am & & & - & - \\
0.1 & 29.3 & 32200 & - & - \\
0.3 & 30.0 & 31100 & - & - \\
0.6 & 30.0 & 31500 & - & - \\
0.9 & 29.5 & 34000 & - & - \\
1.2 & 29.5 & 36000 & - & -
\end{tabular}

SJ VORTAC - Torrecilla Lagoon - 50050358 - depth 0.8 meters

March 16, 1995 - 10:30 am

$\begin{array}{lllll}0.1 & 24.5 & 48500 & 7.7 & 5.2 \\ 0.5 & 24.5 & 51500 & 7.6 & 5.0 \\ 0.8 & 54000 & 7.6 & 4.8\end{array}$

May 17, $1995-11: 10$ am

$\begin{array}{rrrrr}0.1 & 28.7 & 27500 & 8.0 & 6.8 \\ 1.5 & - & 41000 & - & -\end{array}$

July 20,1995 - 9:50 am

$\begin{array}{lllll}0.1 & 30.0 & 46500 & 7.9 & 5.9 \\ 0.2 & 30.1 & 46400 & 7.9 & 5.9 \\ 0.4 & 30.1 & 46700 & 7.9 & 5.8 \\ 0.6 & 30.1 & 46600 & 7.9 & 5.8\end{array}$

Torrecilla Lagoon \#1 - Boca de Cangrejos - 50050375 - depth 4.0 meters

March 16, 1995 - 11:00 am

$\begin{array}{lrrrr}0.1 & 27.7 & 55800 & 7.7 & 5.0 \\ 0.5 & 25.6 & 56100 & 7.7 & 5.1 \\ 0.8 & 25.6 & 56200 & 7.7 & 5.1 \\ 1 & 25.7 & 56500 & 7.7 & 5.1 \\ 1.5 & 25.7 & 56600 & 7.7 & 5.1 \\ 2 & 25.6 & 56700 & 7.7 & 5.1 \\ 2.5 & 25.6 & 56600 & 7.7 & 5.1 \\ 3 & 25.6 & 56800 & 7.7 & 5.1 \\ 3.5 & 25.7 & 56900 & 7.7 & 5.1 \\ 4 & 25.7 & 57000 & 7.7 & 5.2 \\ 17,1995-\mathrm{I0}: 45 \text { am } & & & & 3.6 * \\ 0.1 & 29.0 & 32500 & 7.6 & -\end{array}$

*Note: 2 surface grabs analyzed by Winkler titration. Both measured 3.6 
Appendix 1. In-situ determination of specific conductance, $\mathrm{pH}$, and dissolved oxygen levels with depth for sediment and water quality sites sampled in March, May, and July 1995, San Juan Bay estuary system, Puerto Rico-Continued

\begin{tabular}{|c|c|c|c|c|}
\hline $\begin{array}{l}\text { Depth } \\
(\mathrm{m})\end{array}$ & Temperature $\left({ }^{\circ} \mathrm{C}\right)$ & $\begin{array}{c}\text { Specific } \\
\text { conductance } \\
\left(\mu \mathrm{S} / \mathrm{cm} \text { at } 25^{\circ} \mathrm{C}\right)\end{array}$ & $\begin{array}{c}\mathrm{pH} \\
\text { (standard units) }\end{array}$ & $\begin{array}{l}\text { Dissolved oxygen } \\
(\mathrm{mg} / \mathrm{L})\end{array}$ \\
\hline
\end{tabular}

TRC200 - Torrecilla Core Site - 50050357 - depth 0.9 meters

July 18,1995 - 12:45 pm

$\begin{array}{lllll}0.1 & 28.8 & 46600 & 7.6 & 4.3 \\ 0.3 & 29.5 & 46700 & 7.6 & 4.1 \\ 0.5 & 29.6 & 46900 & 7.7 & 3.9\end{array}$

PNN100 - Piñones Core Site - 50050344 - depth 0.9 meters

July 18, 1995 - 11:40 am

$\begin{array}{lllll}0.1 & 29.3 & 47200 & 8.1 & 5.1 \\ 0.5 & 29.2 & 47400 & 8.1 & 5.1 \\ 0.7 & 29.3 & 47400 & 8.1 & 5.1\end{array}$

Piñones Lagoon \#3 - Northern End - 50050335 - depth 1.0 meter

March 16, 1995 - 12:45 pm

$\begin{array}{lllll}0.1 & 25.4 & 45500 & 8.0 & 6.1 \\ 0.5 & 25.4 & 45500 & 8.1 & 6.0\end{array}$

May 17, 1995 - 9:50 am

$\begin{array}{rrrrr}0.1 & 29.7 & 18490 & 7.9 & 10.3 \\ 0.8 & 29.5 & 19700 & 8.3 & 5.8\end{array}$

July 20, 1995 - 9:15 am

$\begin{array}{lllll}0.1 & 30.1 & 48200 & 8.4 & 7.3 \\ 0.3 & 30.1 & 48200 & 8.4 & 7.3 \\ 0.5 & 30.1 & 48100 & 8.4 & 7.3\end{array}$

Piñones Drainage Canal - Central Canal - 50050338

March 16, 1995 - 12:10 am

0.1

25.5

May 17, 1995 - 9:25 am

$\begin{array}{ll}0.1 & 25.7 \\ 0.5 & 25.4\end{array}$

July 20, 1995 - 9:00 am

0.1

0.15

29.6

29.7
25.7

25.4
45300

9900

10100

49000

49100
7.4

5.5

6.3

7.4

7.4
4.3

3.9

5.1

5.1

.1

6.1

6.0

0.3

8

7.3

7.3

7.3

3.7

7.3

7.2

$1.0 \mathrm{~J}$

$1.1 \mathrm{~J}$ 
Appendix 2. Secchi depth, color, turbidity, and total suspended solids in the surface waters for 15 exploratory water-quality sites sampled during March 1995 (dry-weather period) and May 1995 (wet weather period), San Juan Bay estuary system, Puerto Rico

[Sample locations ar given in table 2 and shown on figures 7,8, and 9. Refer to appendix 1 for the exact dates and times that a given station was sampled in March and May. The Fore-Ule color scale ranges from $I$ for deep ocean blue water to XXI for brown waters typical of eutrophic and dystrophic waters. Turbidity values qualified $J H$ were analyzed after the required holding time of 2 days. The actual hoding times for these samples varied between 5 and 7 days. Abbreviations: $\mathrm{m}$, meter; NTU, nephelometric turbidity units; mg/L, milligrams per liter; - -, no data]

\begin{tabular}{|c|c|c|c|c|c|c|c|c|}
\hline \multirow{2}{*}{$\begin{array}{l}\text { USGS station } \\
\text { name/number }\end{array}$} & \multicolumn{2}{|c|}{ Secchi depth $(m)$} & \multicolumn{2}{|c|}{ Color (Fore-Ule) } & \multicolumn{2}{|c|}{ Turbidity (NTU) } & \multicolumn{2}{|c|}{$\begin{array}{l}\text { Total suspended } \\
\text { solids (mg/L) }\end{array}$} \\
\hline & Dry & Wet & Dry & Wet & Dry & Wet & Dry & Wet \\
\hline $\begin{array}{l}\text { San Juan Bay \#1 } \\
50048620\end{array}$ & 1.13 & 1.52 & VII & XII & $3.1 \mathrm{JH}$ & $1.3 \mathrm{JH}$ & 10.0 & 9.8 \\
\hline $\begin{array}{l}\text { San Juan Bay \#2 } \\
50048630\end{array}$ & 0.70 & 1.07 & XII & $\mathrm{V}$ & $11 \mathrm{JH}$ & $1.9 \mathrm{JH}$ & 30.9 & 17.5 \\
\hline $\begin{array}{l}\text { San Juan Bay \#4 } \\
50049930\end{array}$ & 0.73 & 0.79 & XIV & XVI & $4.4 \mathrm{JH}$ & $3.5 \mathrm{JH}$ & 24.0 & 13.7 \\
\hline $\begin{array}{l}\text { San Juan Bay Pylon \#5 } \\
50049925\end{array}$ & - & 0.43 & XII & XIV & $4.8 \mathrm{JH}$ & $7.8 \mathrm{JH}$ & 15.7 & 20.0 \\
\hline $\begin{array}{l}\text { MPN500 } \\
50049850\end{array}$ & - & 0.27 & XVII & XVI & $2.75 \mathrm{JH}$ & $5.3 \mathrm{JH}$ & 13.0 & 9.2 \\
\hline $\begin{array}{l}\text { Martín Peña at Barbosa } \\
\text { Bridge } \\
50049840\end{array}$ & - & 0.30 & XVI & XVIII & $2.5 \mathrm{JH}$ & $7.7 \mathrm{JH}$ & 7.5 & 10.9 \\
\hline $\begin{array}{l}\text { San José Lagoon \#2 } \\
50049820\end{array}$ & 0.94 & 0.79 & XVIII & XVI & $0.6 \mathrm{JH}$ & 7.3 & 4.6 & 8.7 \\
\hline $\begin{array}{l}\text { San José Lagoon \#3 } \\
50049720\end{array}$ & 0.85 & 0.67 & XVIII & XVI & $5.9 \mathrm{JH}$ & 1.4 & 9.6 & 4.6 \\
\hline $\begin{array}{l}\text { Laguna Gardens } \\
50049745\end{array}$ & 0.82 & 0.94 & XVI & $X V$ & $2 \mathrm{JH}$ & 6.5 & 5.2 & 6.4 \\
\hline $\begin{array}{l}\text { Suárez Canal at Hwy } 28 \\
50050353\end{array}$ & - & - & $\mathrm{XV}$ & $\mathrm{XV}$ & $2.1 \mathrm{JH}$ & 4.3 & 13.7 & 5.39 \\
\hline $\begin{array}{l}\text { Torrecilla Lagoon \#3 } \\
50050355\end{array}$ & 0.52 & 1.13 & XIV & $\mathrm{XV}$ & $5.9 \mathrm{JH}$ & 5.2 & 20.8 & 6.1 \\
\hline $\begin{array}{l}\text { SJ VORTAC } \\
50050358\end{array}$ & 0.82 & 0.49 & XIV & XVI & $4.6 \mathrm{JH}$ & 9.1 & 8.3 & 10.1 \\
\hline $\begin{array}{l}\text { Torrecilla Lagoon \# l } \\
50050375\end{array}$ & 1.46 & 0.67 & $X$ & XV & $2.4 \mathrm{JH}$ & 6.8 & 9.0 & 6.4 \\
\hline $\begin{array}{l}\text { Piñones \#3 } \\
50050335\end{array}$ & - & 0.37 & $\mathrm{XX}$ & XXI & $3.5 \mathrm{JH}$ & 8.5 & 17.0 & 11.0 \\
\hline $\begin{array}{l}\text { Piñones Drainage Canal } \\
50050338\end{array}$ & 0.37 & 0.12 & XXI & XXI & $4.6 \mathrm{JH}$ & 2.6 & 14.6 & 4.5 \\
\hline
\end{tabular}


Appendix 3. Analytical results for dissolved nutrients, fecal coliform bacteria, and chlorophyll 'a' and 'b' for 15 exploratory water-quality sites sampled during March 1995 (dry-weather period) and May 1995 (wet-weather period), San Juan Bay estuary system, Puerto Rico

[Sample locations are given in table 2 and shown on figures 7,8, and 9. Refer to appendix 1 for the exact dates and times that a given station was sampled in March and May. Nitrate values were calculated by subtracting the nitrite values from the nitrate+nitrite values. Data quality codes: U, value less than the detection level indicated; UB, value is the maximum estimated concentration of fecal coliform bacteria colonies present in the sample; JB, the number of colonies of fecal coliform bacteria counted was outside of the ideal plate count of 20 to 60 colonies; XB, value is the minimum estimated concentration of fecal coliform bacteria colonies present in the sample. Abbreviations: $\mathrm{m}, \mathrm{meter} ; \mathrm{N}, \mathrm{Nitrogen} ; \mathrm{P}$,

Phosphorus; DI, deionized; NTU, nephelometric turbidity units; $\mu \mathrm{g} / \mathrm{L}$, micrograms per liter; $\mathrm{mg} / \mathrm{L}$, milligrams per liter, col/100 ml, colonies per 100 milliliters]

\begin{tabular}{|c|c|c|c|c|c|c|c|c|c|}
\hline 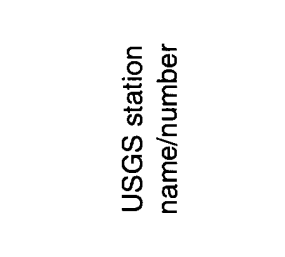 & 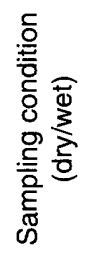 & 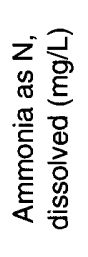 & 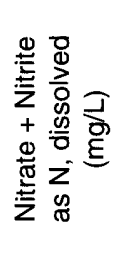 & 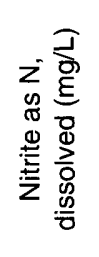 & 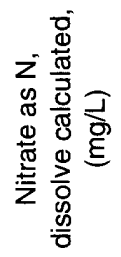 & 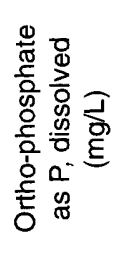 & 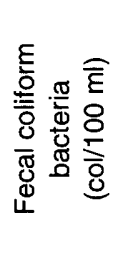 & 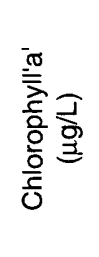 & 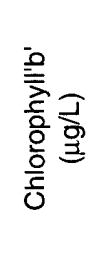 \\
\hline San Juan Bay \#1 & Dry & 0.03 & 0.02 & $0.01 \mathrm{U}$ & $0.02 \mathrm{~J}$ & 0.01 & $10 \mathrm{UB}$ & 1 & $0.1 \mathrm{U}$ \\
\hline 50048620 & Wet & 0.09 & 0.03 & $0.01 \mathrm{U}$ & 0.03 & 0.04 & 58 & 0.6 & $0.1 \mathrm{U}$ \\
\hline San Juan Bay \#2 & Dry & 0.07 & 0.05 & $0.01 \mathrm{U}$ & 0.05 & 0.02 & $100 \mathrm{UB}$ & 3.6 & $0.1 \mathrm{U}$ \\
\hline 50048630 & Wet & 0.04 & 0.02 & $0.01 \mathrm{U}$ & 0.02 & 0.03 & $18 \mathrm{JB}$ & 1.1 & $0.1 \mathrm{U}$ \\
\hline San Juan Bay \#4 & Dry & 0.05 & 0.03 & $0.01 \mathrm{U}$ & 0.03 & 0.02 & $100 \mathrm{JB}$ & 1.6 & 0.2 \\
\hline 50049930 & Wet & 0.07 & 0.03 & $0.01 \mathrm{U}$ & 0.03 & 0.03 & 111 & 5 & $0.1 \mathrm{U}$ \\
\hline San Juan Bay Pylon \#5 & Dry & 0.15 & 0.04 & $0.01 \mathrm{U}$ & 0.04 & 0.03 & 4000 & 5.1 & 0.5 \\
\hline 50049925 & Wet & 0.09 & 0.03 & $0.01 \mathrm{U}$ & 0.03 & 0.03 & $300 \mathrm{JB}$ & 7.2 & $0.1 \mathrm{U}$ \\
\hline MPN501 & Dry & 1.6 & 0.03 & $0.01 \mathrm{U}$ & 0.03 & 0.24 & 270000 & 87 & 15 \\
\hline 50049850 & Wet & 2 & 0.02 & 0.01 & 0.01 & 0.21 & 420000 & 40 & 0.6 \\
\hline Martín Peña at Barbosa & Dry & 2.3 & 0.03 & 0.01 & 0.02 & 0.22 & 610000 & 1.6 & 0.1 \\
\hline Bridge 50049840 & Wet & 2.3 & 0.04 & 0.01 & 0.03 & 0.14 & 350000 & 67 & 1.8 \\
\hline San José Lagoon \#2 & Dry & 0.36 & 0.04 & 0.01 & 0.03 & 0.08 & 2500 & 1.5 & $0.1 \mathrm{U}$ \\
\hline 50049820 & Wet & 0.05 & $0.02 \mathrm{U}$ & $0.01 \mathrm{U}$ & 0.01 & 0.04 & 4400 & 6.4 & 0.8 \\
\hline San José Lagoon \#3 & Dry & 0.06 & 0.12 & 0.01 & 0.11 & 0.05 & 280 & 20 & 1.2 \\
\hline 50049720 & Wet & 0.32 & 0.04 & 0.01 & 0.03 & 0.08 & 6000 & 8 & 1.1 \\
\hline Laguna Gardens & Dry & 0.04 & 0.02 & $0.01 \mathrm{U}$ & 0.02 & 0.01 & 460 & 6.2 & 0.9 \\
\hline 50049745 & Wet & 0.15 & 0.16 & 0.02 & 0.14 & 0.1 & 2100 & 4 & 0.2 \\
\hline Suárez Canal at Hwy 28 & Dry & 0.06 & $0.02 \mathrm{U}$ & $0.01 \mathrm{U}$ & 0.01 & $0.01 \mathrm{U}$ & $120 \mathrm{JB}$ & 4.4 & 0.6 \\
\hline 50050353 & Wet & 0.45 & 0.06 & 0.01 & 0.05 & 0.17 & $600 \mathrm{XB}$ & 8.1 & 0.8 \\
\hline
\end{tabular}


Appendix 3. Analytical results for dissolved nutrients, fecal coliform bacteria, and chlorophyll ' $a$ ' and ' $b$ ' for 15 exploratory water-quality sites sampled during March 1995 (dry period) and May 1995 (wet period), San Juan Bay estuary system, Puerto Rico-Continued

\begin{tabular}{|c|c|c|c|c|c|c|c|c|c|}
\hline 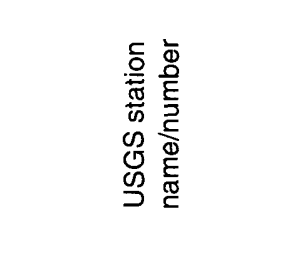 & 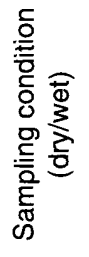 & 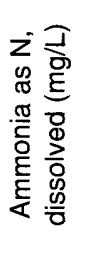 & 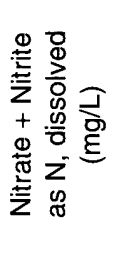 & 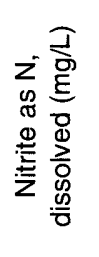 & 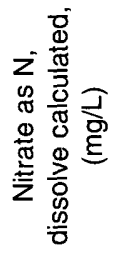 & 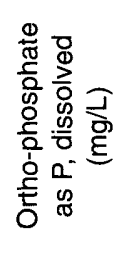 & 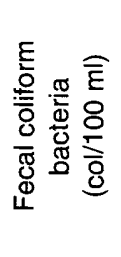 & 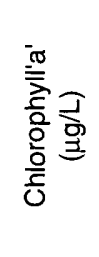 & 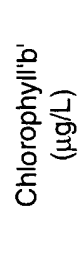 \\
\hline Torrecilla Lagoon \#3 & Dry & 0.04 & 0.02 & $0.01 \mathrm{U}$ & 0.02 & 0.01 & $100 \mathrm{JB}$ & 3.3 & 0.3 \\
\hline 50050355 & Wet & 0.43 & 0.06 & 0.01 & 0.05 & 0.16 & $600 \mathrm{XB}$ & 6.2 & 0.3 \\
\hline SJ VORTAC & Dry & 0.06 & 0.02 & $0.01 \mathrm{U}$ & 0.02 & 0.01 & $10 \mathrm{UB}$ & 3.5 & 0.2 \\
\hline 50050358 & Wet & 0.05 & 0.12 & 0.02 & 0.1 & 0.03 & $600 \mathrm{XB}$ & 21 & 1.6 \\
\hline Torrecilla Lagoon \#1 & Dry & 0.05 & 0.03 & $0.01 \mathrm{U}$ & 0.03 & 0.01 & $10 \mathrm{JB}$ & $0.1 \mathrm{U}$ & $0.1 \mathrm{U}$ \\
\hline 50050375 & Wet & 0.11 & 0.12 & 0.01 & 0.11 & 0.04 & $1200 \mathrm{JB}$ & 19 & 1.5 \\
\hline Piñones \#3 & Dry & 0.05 & $0.02 \mathrm{U}$ & $0.01 \mathrm{U}$ & 0.01 & 0.01 & $10 \mathrm{UB}$ & 8.2 & $0.1 \mathrm{U}$ \\
\hline 50050335 & Wet & 0.09 & 0.04 & 0.01 & 0.03 & 0.02 & $600 \mathrm{XB}$ & 45 & 0.9 \\
\hline Piñones Drainage Canal & Dry & 0.06 & $0.02 \mathrm{U}$ & 0.01 & $0.01 \mathrm{U}$ & 0.02 & $120 \mathrm{JB}$ & 12 & 0.5 \\
\hline 50050338 & Wet & 0.06 & $0.02 \mathrm{U}$ & 0.01 & $0.01 \mathrm{U}$ & 0.15 & $600 \mathrm{XB}$ & 5.6 & 0.2 \\
\hline
\end{tabular}


Appendix 4. Particle-size distribution, moisture content, nutrients and total carbon concentrations in surficial bottom sediment samples at nine exploratory designated bottom sediment sampling sites and at the six detailed sediment sampling sites, San Juan Bay estuary system, Puerto Rico

[Sample locations are presented in table 2 and figures 7, 8, and 9. Gravel, mean grain diameter greater than $2 \mathrm{~mm}$; sand, mean grain diameter less than $2 \mathrm{~mm}$ but greater than $0.0625 \mathrm{~mm}$; silt, mean grain diameter less than $0.0625 \mathrm{~mm}$ but greater than $0.002 \mathrm{~mm}$; clay, mean grain diameter less than $0.002 \mathrm{~mm}$. Values for total phosphorus in surface sediments at the nine exploratory sediment sites received a $\mathrm{Z}$ qualifier because the corrections for percent dryness could not be applied; therefore corrections were applied assuming 100 percent dryness yielding a minimum value for nutrient concentrations. Abbreviations: $\mathrm{mm}$, millimeters; $\mathrm{mg} / \mathrm{kg}$, milligrams per kilogram; gm $/ \mathrm{kg}$ grams per kilogram]

\begin{tabular}{|c|c|c|c|c|c|c|c|}
\hline \multicolumn{4}{|c|}{ Grain Size } & \multirow{3}{*}{$\begin{array}{l}\text { Moisture } \\
\text { content, } \\
\text { (percent) of } \\
\text { total, dry } \\
\text { weight }\end{array}$} & \multirow{3}{*}{$\begin{array}{c}\text { Nitrogen, } \\
\text { ammonia plus } \\
\text { organic, total in } \\
\text { bottom material, } \\
\text { dry weight } \\
(\mathrm{mg} / \mathrm{kg} \text { as } \mathrm{N})\end{array}$} & \multirow{3}{*}{$\begin{array}{l}\text { Phosphorus } \\
\text { total in bottom } \\
\text { material, dry } \\
\text { weight } \\
(\mathrm{mg} / \mathrm{kg} \text { as } \mathrm{P})\end{array}$} & \multirow{3}{*}{$\begin{array}{c}\text { Carbon, inorganic } \\
\text { plus organic total } \\
\text { in bottom } \\
\text { material, dry } \\
\text { weight } \\
(\mathrm{gm} / \mathrm{kg} \text { as } \mathrm{C})\end{array}$} \\
\hline Gravel & Sand & Silt & Clay & & & & \\
\hline \multicolumn{4}{|c|}{ weight percent } & & & & \\
\hline
\end{tabular}

San Juan Bay No. 2 - Pyramid - 50048630 - July 19, 1995 - 8:30 am - Brown, grey silty mud with shell fragments
0
$2 \quad 54$
44
68
10000
$600 \mathrm{Z}$
35

San Juan Bay No. 4 at San Juan - South end of Bay - 50049930 - July 19, 1995 - 9:10 am - Dark green sandy mud with occasional shell fragments
0
$8 \quad 67$
25
61
9200
$530 \mathrm{Z}$
45

San Juan Bay Core Site (SJN600) - Inside dredge triangle - 50049935 - December 16, 1995 - 10:00 am - Dark green, poorly consolidated mud
0
1
63
36
54
1300
600
40

San Juan Bay Pylon \#5 - 50049925 - July 19, 1995 - 12:00 pm - Mottled brown black sand mud with leaf debris and shell fragments

$\begin{array}{llllllll}25 & 19 & 34 & 22 & 58 & 9200 & 560 \mathrm{Z} & 32\end{array}$

Martín Peña Core Site (MPN500)- near Ponce de Leon - 50049850 - December 16, 1994 - 11:30 am - Black organic -rich sand and silt with abundant leaves and twigs, strong smell of hydrocarbons
0
79
14
7
29
1100
560
42

Martín Peña Canal at Barbosa Bridge at San Juan - 50049840 - July 20, 1995 - 11:50 am - Black sandy mud with leaf debris and twigs
1
38
41
20
73
27000
$810 \mathrm{Z}$
61

Los Corozos Core Site (CRZ400) - 50049710 - December 15, 1994 - 3:00 pm - Dark green, organic-rich, mud with abundant shell fragments
l
$4 \quad 59$
36
36
2300
930
110

San José Core Site (SJS300) - 50049755 - December 15, 1994 - 12:30 pm - Poorly consolidated, dark grey organic rich mud with abundant shell fragments
10
$12 \quad 38$
40
38
1900
550
48

Laguna Gardens - 50049745 - July 20, 1995 - 1045 - Dark brown to black organic-rich sandy mud

$\begin{array}{lllllll}0 & 2 & 63 & 35 & 86 & 37000 & 540 \mathrm{Z}\end{array}$

$40 \mathrm{Z}$

58

Suárez Canal at Highway 26 Bridge near Carolina (no deposition under bridge so sample is from dredge area approximately 100 meters west of marginal road bridge west of Highway 26) - 50050353 - July 20, 1995 - 10:15 am - Dark brown to black, organic-rich muddy sand with abundant leaf debris and twigs
0
57
31
12
76
23000
$550 \mathrm{Z}$

120

SJ VORTAC - east of airport beacon - 50050358 - July 20, 1995 - 9:50 am - Dark brown, organic-rich sandy mud with leaf debris and abundant shell fragments

29

64

7

66

11000

$480 \mathrm{Z}$

86 
Appendix 4. Particle-size distribution, moisture content, nutrients and total carbon concentrations in surficial bottom sediment samples at nine exploratory designated bottom sediment sampling sites and at the six detailed sediment sampling sites, San Juan Bay estuary system, Puerto Rico-Continued

\begin{tabular}{ccccccc}
\hline Grain Size & Silt & Clay & $\begin{array}{c}\text { Moisture } \\
\text { content, } \\
\text { (percent) of } \\
\text { total, dry } \\
\text { weight }\end{array}$ & $\begin{array}{c}\text { Nitrogen, } \\
\text { ammonia plus } \\
\text { organic, total in } \\
\text { bottom material, } \\
\text { dry weight } \\
(\mathrm{mg} / \mathrm{kg} \text { as N) }\end{array}$ & $\begin{array}{c}\text { Phosphorus } \\
\text { total in bottom } \\
\text { material, dry } \\
\text { weight } \\
(\mathrm{mg} / \mathrm{kg} \text { as P) }\end{array}$ & $\begin{array}{c}\text { Carbon, inorganic } \\
\text { plus organic total } \\
\text { in bottom } \\
\text { material, dry } \\
\text { weight } \\
(\mathrm{gm} / \mathrm{kg} \mathrm{as} \mathrm{C)}\end{array}$ \\
\hline
\end{tabular}

Torrecilla Core Site (TRC200) - North of Punta Mosquitos - 50050357 - December 15, 1994 - 9:30 am - Reddish brown peat with abundant shell fragments
26
933
32
28
1800
350
64

Piñones core site (PNN100) - south end - 50050344 - December 14, 1994 - 2:00 pm - Reddish brown peat with abundant shell fragments
52
$10 \quad 22$
16
56
2500
330
47

Piñones Lagoon No 3 near Carolina - North end - 50050335 - July 20, 1995 - 9:15 am - Dark brown, organic-rich sandy mud with abundant shell fragments
0
13
63
24
82
38000
$450 \mathrm{Z}$
70

Piñones Drainage Canal - Central canal - 50050338 - July 20, 1995 - 8:45 am - Dark brown sandy mud with leaf debris and shell fragments 
Appendix 5. Particle-size distribution and cesium-137 analytical results for discrete depth intervals at six bottom sediment core sites, San Juan Bay estuary system, Puerto Rico

[Sample locations are given in table 2 and shown on figures 7, 8, and 9. Gravel, mean grain diameter greater than $2 \mathrm{~mm}$; sand, mean grain diameter less than $2 \mathrm{~mm}$ but greater than $0.0625 \mathrm{~mm}$; silt, mean grain diameter less than $0.0625 \mathrm{~mm}$ but greater than $0.002 \mathrm{~mm}$; clay, mean grain diameter less than $0.002 \mathrm{~mm}$. Abbreviations: $\mathrm{cm}$, centimeters; $\mathrm{mBq} / \mathrm{gm}$, milliBequerels per gram; $\mathrm{U}$, cesium-137 activity less than the indicated minimum reporting level; \%, percent, $\mathrm{mm}$, millimeter]

\begin{tabular}{|c|c|c|c|c|c|c|c|}
\hline Top & Bottom & Gravel & Sand & Silt & $\mathrm{Cla}$ & \multirow[b]{2}{*}{ Verbal equivalent } & \multirow[b]{2}{*}{$\begin{array}{l}\mathrm{Cs}-137 \\
(\mathrm{mBq} / \mathrm{g})\end{array}$} \\
\hline $\begin{array}{r}\text { Depth } \\
\text { water int } \\
\text { in }\end{array}$ & $\begin{array}{l}\text { sediment/ } \\
\text { of sampled } \\
\mathrm{cm} \text { ) }\end{array}$ & \multicolumn{4}{|c|}{ Weight percent } & & \\
\hline SJN600 - & $\begin{array}{l}935 \text { - Water } \\
\text { Dark gre } \\
\text { Dark gre }\end{array}$ & $\begin{array}{l}\text { th } 3.7 \mathrm{~m} \\
\text { poorly } \mathrm{c} \\
\text { compact }\end{array}$ & $\begin{array}{l}\text { Decem } \\
\text { dated } m \\
\text { d with : }\end{array}$ & $\begin{array}{r}6,199 \\
\text { ximate }\end{array}$ & rcent & agments & \\
\hline 0 & 5 & 0 & 1 & 63 & 36 & Clayey Silt & 3.6 \\
\hline 5 & 10 & 0 & 0 & 58 & 42 & Clayey Silt & 1.8 \\
\hline 10 & 15 & 0 & 1 & 59 & 40 & Clayey Silt & 1.4 \\
\hline 15 & 20 & 0 & 2 & 57 & 41 & Clayey Silt & $1 \mathrm{U}$ \\
\hline 20 & 25 & 0 & 2 & 58 & 40 & Clayey Silt & 1.6 \\
\hline 25 & 30 & 0 & 1 & 57 & 42 & Clayey Silt & $1 \mathrm{U}$ \\
\hline 30 & 35 & 0 & 2 & 61 & 37 & Clayey Silt & $1 \mathrm{U}$ \\
\hline 35 & 40 & 1 & 2 & 63 & 34 & Clayey Silt & $1 \mathrm{U}$ \\
\hline 40 & 45 & 3 & 2 & 60 & 35 & Clayey Silt & $1 \mathrm{U}$ \\
\hline 45 & 50 & 0 & 2 & 57 & 41 & Clayey Silt & $1 \mathrm{U}$ \\
\hline 50 & 55 & 1 & 2 & 56 & 41 & Clayey Silt & $1 \mathrm{U}$ \\
\hline 55 & 60 & 1 & 1 & 61 & 37 & Clayey Silt & $1 \mathrm{U}$ \\
\hline
\end{tabular}

MPN500 - 50049850 - Water depth 0.7 meters - December 16, 1994 - 11:30 am

Physical description below from core sampled on July 19, 1995

$0-50 \mathrm{~cm}$ Black organic-rich sand and silt. abundant leaves and twigs, strong smell of hydrocarbons

$50-140 \mathrm{~cm} \quad$ Black organic-rich sand and silt with grey clay layers $2-5 \mathrm{~cm}$ thick

140-165 cm Dark brown organic-rich sand and silt, with layers of shell fragments and layers of peat

$165-185 \mathrm{~cm}$ Tan brown with grey sandy clay

$\begin{array}{rrrrrrll}0 & 10 & 0 & 79 & 14 & 7 & \text { Sand } & 5.3 \\ 10 & 20 & 5 & 61 & 22 & 12 & \text { Silty Sand } & 7.2 \\ 20 & 30 & 1 & 57 & 27 & 15 & \text { Silty Sand } & 7.8 \\ 30 & 40 & 0 & 49 & 31 & 20 & \text { Silty Sand } & 7.2 \\ 40 & 50 & 0 & 11 & 57 & 32 & \text { Clayey Silt } & 4.7 \\ 50 & 60 & 0 & 5 & 52 & 43 & \text { Clayey Silt } & 5.4 \\ 60 & 70 & 0 & 1 & 49 & 50 & \text { Silty Clay } & 6.5 \\ 70 & 80 & 0 & 5 & 55 & 40 & \text { Clayey Silt } & 9.7 \\ 80 & 90 & 0 & 5 & 59 & 36 & \text { Clayey Silt } & 15.4 \\ 90 & 100 & 0 & 8 & 55 & 37 & \text { Clayey Silt } & 29.8 \\ 100 & 110 & 0 & 9 & 46 & 45 & \text { Clayey Silt } & 15.1\end{array}$


Appendix 5. Particle-size distribution and cesium-137 analytical results for discrete depth intervals at six bottom sediment core sites, San Juan Bay estuary system, Puerto Rico-Continued

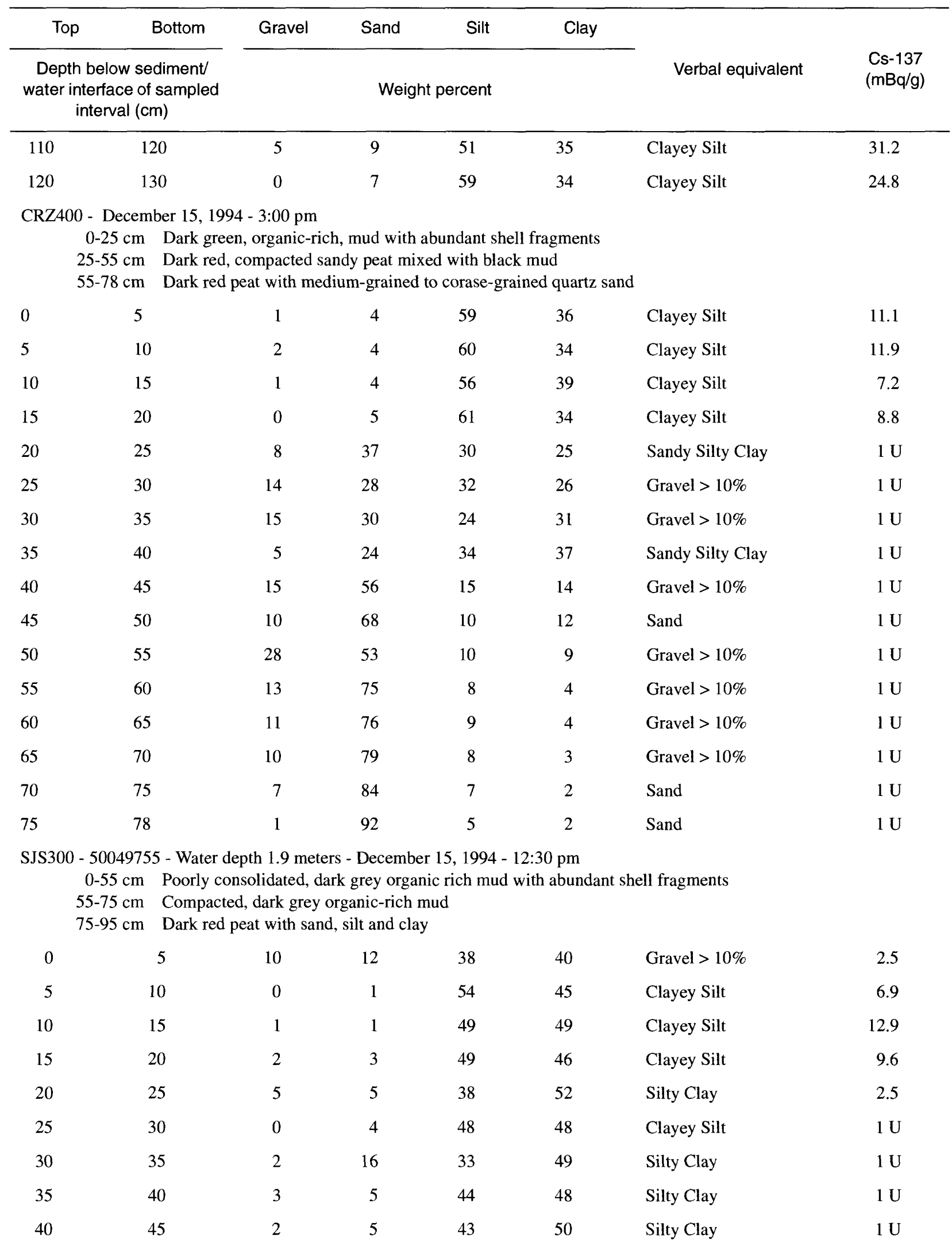


Appendix 5. Particle-size distribution and cesium-137 analytical results for discrete depth intervals at six bottom sediment core sites, San Juan Bay estuary system, Puerto Rico-Continued

\begin{tabular}{|c|c|c|c|c|c|c|c|}
\hline Top & Bottom & Gravel & Sand & Silt & Clay & \multirow[b]{2}{*}{ Verbal equivalent } & \multirow[b]{2}{*}{$\begin{array}{c}\mathrm{Cs}-137 \\
(\mathrm{mBq} / \mathrm{g})\end{array}$} \\
\hline $\begin{array}{r}\text { Depth } \\
\text { water in } \\
\text { ir }\end{array}$ & $\begin{array}{l}\text { ediment/ } \\
\text { of sampled } \\
\mathrm{cm} \text { ) }\end{array}$ & \multicolumn{4}{|c|}{ Weight percent } & & \\
\hline 45 & 50 & 1 & 3 & 41 & 55 & Silty Clay & $1 \mathrm{U}$ \\
\hline 50 & 55 & 1 & 3 & 34 & 62 & Silty Clay & $1 \mathrm{U}$ \\
\hline 55 & 60 & 1 & 5 & 44 & 50 & Silty Clay & $1 \mathrm{U}$ \\
\hline 60 & 65 & 5 & 13 & 29 & 53 & Silty Clay & $1 \mathrm{U}$ \\
\hline 65 & 70 & 10 & 11 & 33 & 46 & Sandy Silty Clay & $1 \mathrm{U}$ \\
\hline 70 & 75 & 5 & 8 & 39 & 48 & Silty Clay & $1 \mathrm{U}$ \\
\hline 75 & 80 & 10 & 12 & 43 & 35 & Gravel $>10 \%$ & $1 \mathrm{U}$ \\
\hline 80 & 85 & 0 & 0 & 60 & 40 & Clayey Silt & 2.1 \\
\hline 85 & 90 & 0 & 0 & 77 & 23 & Silt & 3.5 \\
\hline 90 & 95 & 0 & 0 & 83 & 17 & Silt & $1 \mathrm{U}$ \\
\hline
\end{tabular}

TRC200 - 50050357 - Water depth 0.9 meters - December 15, 1994 - 10:30 am $0-85 \mathrm{~cm}$ Reddish brown peat with abundant shell fragments $85-102 \mathrm{~cm}$ Reddish peat with layers of grey clay

$\begin{array}{lrrrrlll}0 & 5 & 26 & 9 & 33 & 32 & \text { Gravel > 10\% } & 4.5 \\ 5 & 10 & 25 & 16 & 36 & 23 & \text { Gravel > 10\% } & 1 \mathrm{U} \\ 10 & 15 & 9 & 23 & 42 & 26 & \text { Sandy Silty Clay } & 1.2 \\ 15 & 20 & 0 & 0 & 66 & 34 & \text { Clayey Silt } & 1 \mathrm{U} \\ 20 & 25 & 0 & 0 & 62 & 38 & \text { Clayey Silt } & 1 \mathrm{U} \\ 25 & 30 & 0 & 0 & 62 & 38 & \text { Clayey Silt } & 1 \mathrm{U} \\ 30 & 35 & 0 & 0 & 72 & 28 & \text { Clayey Silt } & 1 \mathrm{U} \\ 35 & 40 & 0 & 0 & 70 & 30 & \text { Clayey Silt } & 1 \mathrm{U} \\ 40 & 45 & 0 & 0 & 70 & 30 & \text { Clayey Silt } & 1 \mathrm{U} \\ 45 & 50 & 0 & 0 & 72 & 28 & \text { Clayey Silt } & 1.2 \\ 50 & 55 & 0 & 0 & 73 & 27 & \text { Clayey Silt } & 1 \mathrm{U} \\ 55 & 60 & 0 & 0 & 77 & 23 & \text { Silt } & 1 \mathrm{U} \\ 60 & 65 & 0 & 0 & 73 & 27 & \text { Clayey Silt } & 1 \mathrm{U} \\ 65 & 70 & 0 & 0 & 77 & 23 & \text { Silt } & 1 \mathrm{U} \\ 70 & 75 & 0 & 0 & 74 & 26 & \text { Clayey Silt } & 1 \mathrm{U} \\ 75 & 80 & 0 & 0 & 74 & 26 & \text { Clayey Silt } & 1 \mathrm{U} \\ 80 & 85 & 0 & 0 & 75 & 25 & \text { Clayey Silt } & 1 \mathrm{U} \\ 85 & 90 & 0 & 0 & 76 & 24 & \text { Silt } & 1 \mathrm{U} \\ 90 & 102 & 0 & 0 & 78 & 22 & \text { Silt } & 1 \mathrm{U}\end{array}$


Appendix 5. Particle-size distribution and cesium-137 analytical results for discrete depth intervals at six bottom sediment core sites, San Juan Bay estuary system, Puerto Rico-Continued

\begin{tabular}{|c|c|c|c|c|c|c|c|}
\hline Top & Bottom & Gravel & Sand & Silt & Clay & \multirow[b]{2}{*}{ Verbal equivalent } & \multirow[b]{2}{*}{$\begin{array}{l}\text { Cs-137 } \\
(\mathrm{mBq} / \mathrm{g})\end{array}$} \\
\hline $\begin{array}{r}\text { Depth } \\
\text { water int } \\
\text { in }\end{array}$ & $\begin{array}{l}\text { ediment/ } \\
\text { f sampled } \\
\text { (m) }\end{array}$ & \multicolumn{4}{|c|}{ Weight percent } & & \\
\hline \multicolumn{8}{|c|}{$\begin{aligned} & \text { PNN100 - 50050344 - Water depth } 0.9 \text { meters - December } 14,1994-2: 00 \mathrm{pm} \\
& 0-45 \mathrm{~cm} \text { Reddish brown peat with abundant bivalves and shell fragments } \\
& 45-70 \mathrm{~cm} \text { Grey clay and silt }\end{aligned}$} \\
\hline 0 & 5 & 52 & 10 & 22 & 16 & Gravel $>10 \%$ & 1.49 \\
\hline 5 & 10 & 32 & 25 & 23 & 20 & Gravel $>10 \%$ & 1.18 \\
\hline 10 & 15 & 40 & 21 & 22 & 17 & Gravel $>10 \%$ & $1 \mathrm{U}$ \\
\hline 15 & 20 & 58 & 19 & 17 & 6 & Gravel $>10 \%$ & $1 \mathrm{U}$ \\
\hline 20 & 25 & 41 & 24 & 23 & 12 & Gravel $>10 \%$ & $1 \mathrm{U}$ \\
\hline 25 & 30 & 26 & 30 & 31 & 13 & Gravel $>10 \%$ & $1 \mathrm{U}$ \\
\hline 30 & 35 & 23 & 44 & 24 & 9 & Gravel $>10 \%$ & $1 \mathrm{U}$ \\
\hline 35 & 40 & 7 & 21 & 56 & 16 & Sandy Silt & $1 \mathrm{U}$ \\
\hline 40 & 45 & 0 & 8 & 71 & 21 & Clayey Silt & $1 \mathrm{U}$ \\
\hline 45 & 50 & 3 & 11 & 60 & 26 & Clayey Silt & $1 \mathrm{U}$ \\
\hline 50 & 55 & 0 & 3 & 75 & 22 & Silt & $1 \mathrm{U}$ \\
\hline 55 & 60 & 0 & 5 & 81 & 14 & Silt & $1 \mathrm{U}$ \\
\hline 60 & 65 & 0 & 3 & 71 & 26 & Clayey Silt & $1 \mathrm{U}$ \\
\hline 65 & 70 & 0 & 4 & 78 & 18 & Silt & $1 \mathrm{U}$ \\
\hline
\end{tabular}


Appendix 6. Analytical results for organochlorine pesticides and total PCB detected above the minimum reporting level in selected horizons corresponding to depositional periods of 1925-1949, 1950-1974, and 1975-95 at six core sites samples July 18-19, 1995, San Juan Bay estuary system, Puerto Rico

[Sample locations are given in table 2 and shown on figures 7, 8, and 9 and described on table 2. Depth intervals of time horizons listed in table 6. Abbreviations: Cs, cesium; PCB, polychlorinated biphenyl; DDD, dichlorodiphenyldichloroethane; DDE, dichlorodiphenyldichloroethelene; DDT, dichlorodiphenyltrichloroethane; $\mu \mathrm{g} / \mathrm{kg}$, micrograms per kilogram of dry material (parts per trillion); UH, indicates the given concentration determined after the maximum sample holding time, thus the actual concentrations may exceed the stated amounts]

\begin{tabular}{|c|c|c|c|c|c|c|}
\hline $\begin{array}{l}\text { Time horizon } \\
\text { as estimated } \\
\text { from Cs-137 }\end{array}$ & $\begin{array}{l}\text { PCB in bottom } \\
\text { material } \\
\text { ( } \mu \mathrm{g} / \mathrm{kg} \mathrm{dry} \\
\text { solids) }\end{array}$ & $\begin{array}{l}\text { Dieldrin in } \\
\text { bottom } \\
\text { material } \\
\text { ( } \mu \text { g/kg dry } \\
\text { solids) }\end{array}$ & $\begin{array}{l}\text { Chlordane in } \\
\text { bottom } \\
\text { material } \\
\text { ( } \mu \text { g } / \mathrm{kg} \mathrm{dry} \\
\text { solids) }\end{array}$ & $\begin{array}{l}\text { DDD in } \\
\text { bottom } \\
\text { material } \\
\text { ( } \mu \text { g/kg dry } \\
\text { solids) }\end{array}$ & $\begin{array}{l}\text { DDE in } \\
\text { bottom } \\
\text { material } \\
\text { ( } \mu \text { g/kg dry } \\
\text { solids) }\end{array}$ & $\begin{array}{c}\text { DDT in bottom } \\
\text { material } \\
\text { ( } \mu \mathrm{g} / \mathrm{kg} \text { dry } \\
\text { solids) }\end{array}$ \\
\hline \multicolumn{7}{|l|}{ SJN600 } \\
\hline $1975-1995$ & 96 & 0.1 & $1 \mathrm{UH}$ & 0.3 & 0.6 & $0.1 \mathrm{UH}$ \\
\hline $1950-1975$ & 15 & $0.1 \mathrm{UH}$ & $1 \mathrm{UH}$ & 0.1 & 0.3 & $0.1 \mathrm{UH}$ \\
\hline $1925-1950$ & 2 & $0.1 \mathrm{UH}$ & $1 \mathrm{UH}$ & $0.1 \mathrm{UH}$ & $0.1 \mathrm{UH}$ & $0.1 \mathrm{UH}$ \\
\hline \multicolumn{7}{|l|}{ MPN500 } \\
\hline I975-1995 & 450 & 0.25 & 34.5 & 5.65 & 9 & 0.15 \\
\hline $1950-1975$ & 190 & 0.8 & 2 & 5.2 & 40 & 0.4 \\
\hline $1925-1950$ & 12 & $0.1 \mathrm{UH}$ & $1 \mathrm{UH}$ & $0.1 \mathrm{UH}$ & 0.5 & $0.1 \mathrm{UH}$ \\
\hline \multicolumn{7}{|l|}{ CRZ400 } \\
\hline $1975-1995$ & 380 & 1.1 & 7 & 1.8 & 24 & 0.5 \\
\hline $1950-1975$ & 160 & 0.2 & $2 \mathrm{UH}$ & 1.4 & 60 & 0.2 \\
\hline $1925-1950$ & 2 & $0.1 \mathrm{UH}$ & $1 \mathrm{UH}$ & $0.1 \mathrm{UH}$ & $0.1 \mathrm{UH}$ & 0.I UH \\
\hline \multicolumn{7}{|l|}{ SJS300 } \\
\hline $1975-1995$ & 36 & $0.2 \mathrm{UH}$ & $1 \mathrm{UH}$ & 0.2 & 2.2 & $0.1 \mathrm{UH}$ \\
\hline $1950-1975$ & 62 & 1.1 & 1 & 1.9 & 38 & 0.4 \\
\hline $1925-1950$ & $6 \mathrm{UH}$ & $0.2 \mathrm{UH}$ & $2 \mathrm{UH}$ & $0.2 \mathrm{UH}$ & 0.3 & $0.2 \mathrm{UH}$ \\
\hline \multicolumn{7}{|l|}{ TRC200 } \\
\hline 1975-1995 & 4 & $0.1 \mathrm{UH}$ & $1 \mathrm{UH}$ & $0.1 \mathrm{UH}$ & 0.4 & $0.1 \mathrm{UH}$ \\
\hline $1950-1975$ & 3 & $0.1 \mathrm{UH}$ & $1 \mathrm{UH}$ & $0.1 \mathrm{UH}$ & 0.3 & $0.1 \mathrm{UH}$ \\
\hline I925-I950 & $1 \mathrm{UH}$ & $0.1 \mathrm{UH}$ & $1 \mathrm{UH}$ & $0.1 \mathrm{UH}$ & $0.1 \mathrm{UH}$ & $0.1 \mathrm{UH}$ \\
\hline \multicolumn{7}{|l|}{ PNN100 } \\
\hline $1975-1995$ & 19 & $0.2 \mathrm{UH}$ & $2 \mathrm{UH}$ & 0.3 & 1.9 & 0.2 \\
\hline $1950-1975$ & 21 & 0.2 & $2 \mathrm{UH}$ & $0.2 \mathrm{UH}$ & 1.2 & $0.2 \mathrm{UH}$ \\
\hline $1925-1950$ & 4 & $0.1 \mathrm{UH}$ & $1 \mathrm{UH}$ & 0.1 & 0.5 & $0.1 \mathrm{UH}$ \\
\hline
\end{tabular}


Appendix 7. Trace element concentrations in core samples for selected horizons corresponding to depositional periods of 1925-49, 1950-74, and 1975-95 at six core sites sampled July 18-19, 1995, San Juan Bay estuary system, Puerto Rico

[Site locations are described in table 2 and shown on figures 7, 8, and 9. Depth intervals of horizons listed in table 7. Abbreviations: RPD, relative percent difference; $\mu \mathrm{g} / \mathrm{g}$, micrograms per gram (parts per million); $\mathrm{U}$, not detected above this minimum reporting limit]

\begin{tabular}{|c|c|c|c|c|c|c|c|}
\hline $\begin{array}{l}\text { Site time } \\
\text { period } \\
\text { sampled }\end{array}$ & $\begin{array}{c}\text { Arsenic, } \\
\text { total in } \\
\text { bottom } \\
\text { material } \\
(\mu \mathrm{g} / \mathrm{g} \text { as As) }\end{array}$ & $\begin{array}{c}\text { Barium, } \\
\text { total in } \\
\text { bottom } \\
\text { material } \\
(\mu \mathrm{g} / \mathrm{g} \text { as } \mathrm{Ba})\end{array}$ & $\begin{array}{l}\text { Cadmium, } \\
\text { total in } \\
\text { bottom } \\
\text { material } \\
(\mu \mathrm{g} / \mathrm{g} \text { as } \mathrm{Cd})\end{array}$ & $\begin{array}{l}\text { Chromium, } \\
\text { total in } \\
\text { bottom } \\
\text { material } \\
(\mu \mathrm{g} / \mathrm{g} \text { as } \mathrm{Cr})\end{array}$ & $\begin{array}{c}\text { Lead, } \\
\text { total in } \\
\text { bottom } \\
\text { material } \\
(\mu \mathrm{g} / \mathrm{g} \text { as } \mathrm{Pb})\end{array}$ & $\begin{array}{c}\text { Mercury, } \\
\text { recoverable } \\
\text { from } \\
\text { bottom } \\
\text { material } \\
(\mu \mathrm{g} / \mathrm{g} \text { as } \mathrm{Hg})\end{array}$ & $\begin{array}{c}\text { Selenium, } \\
\text { total in } \\
\text { bottom } \\
\text { material } \\
\text { ( } \mu \mathrm{g} / \mathrm{g} \text { as } \mathrm{Se} \text { ) }\end{array}$ \\
\hline \multicolumn{8}{|c|}{ SJN600 (50049935) } \\
\hline $1975-1995$ & 15 & 20 & $1 \mathrm{U}$ & 40 & 50 & 0.29 & $1 \mathrm{U}$ \\
\hline $1950-1975$ & 17 & 10 & $1 \mathrm{U}$ & 40 & 30 & 0.17 & $1 \mathrm{U}$ \\
\hline $1925-1950$ & 18 & 10 & $1 \mathrm{U}$ & 30 & 20 & 0.07 & $1 \mathrm{U}$ \\
\hline \multicolumn{8}{|c|}{ MPN500 (50049850) } \\
\hline 1975-1995 & 10 & 55 & 3 & 55 & 750 & 4.7 & $1 \mathrm{U}$ \\
\hline $1950-1975$ & 10 & 30 & 3 & 40 & 240 & 0.87 & $1 \mathrm{U}$ \\
\hline $1925-1950$ & 8 & 10 & $1 \mathrm{U}$ & 20 & 30 & 0.16 & $1 \mathrm{U}$ \\
\hline \multicolumn{8}{|c|}{ CRZ400 (50049710) } \\
\hline 1975-1995 & 9 & 40 & 3 & 50 & 550 & 0.18 & $1 \mathrm{U}$ \\
\hline $1950-1975$ & 9 & 50 & 3 & 40 & 220 & 0.04 & $1 \mathrm{U}$ \\
\hline $1925-1950$ & 10 & 10 & $1 \mathrm{U}$ & 30 & 20 & 0.09 & $1 \mathrm{U}$ \\
\hline \multicolumn{8}{|c|}{ SJS300 (50049755) } \\
\hline 1975-1995 & 11 & 20 & 1 & 40 & 180 & 0.12 & $1 \mathrm{U}$ \\
\hline $1950-1975$ & 12 & 20 & $1 \mathrm{U}$ & 40 & 50 & 0.09 & $1 \mathrm{U}$ \\
\hline $1925-1950$ & 13 & 10 & $1 \mathrm{U}$ & 40 & 20 & 0.05 & $1 \mathrm{U}$ \\
\hline \multicolumn{8}{|c|}{ TRC200 (50050357) } \\
\hline 1975-1995 & 17 & 20 & $1 \mathrm{U}$ & 40 & 20 & 0.05 & $1 \mathrm{U}$ \\
\hline $1950-1975$ & 21 & 10 & $1 \mathrm{U}$ & 40 & 20 & 0.02 & $1 \mathrm{U}$ \\
\hline $1925-1950$ & 23 & $10 \mathrm{U}$ & $1 \mathrm{U}$ & 30 & 10 & $0.01 \mathrm{U}$ & $1 \mathrm{U}$ \\
\hline \multicolumn{8}{|c|}{ PNN100 (50050344) } \\
\hline 1975-1995 & 7 & 20 & $1 \mathrm{U}$ & 30 & 40 & 0.15 & $1 \mathrm{U}$ \\
\hline $1950-1975$ & 8 & 20 & $1 \mathrm{U}$ & 30 & 30 & 0.06 & $1 \mathrm{U}$ \\
\hline $1925-1950$ & 9 & 30 & $1 \mathrm{U}$ & 30 & 20 & 0.04 & $1 \mathrm{U}$ \\
\hline
\end{tabular}

